$$
\begin{gathered}
\text { UNIVERSIDADE DE SÃO PAULO } \\
\text { FACULDADE DE EDUCAÇÃO } \\
\text { PROGRAMA DE PÓS GRADUAÇÃo EM EDUCAÇÃO }
\end{gathered}
$$

IETE RODRIGUES REIS

MEMÓRIA SOCIAL E EDUCAÇÃO RURAL NO MUNICÍPIO DE ATIBAIA-SP (1964-1985): UM ESTUDO DE CASO. 


\title{
IETE RODRIGUES REIS
}

\section{MEMÓRIA SOCIAL E EDUCAÇÃO RURAL NO MUNICÍPIO DE ATIBAIA-SP} (1964-1985): UM ESTUDO DE CASO.

\author{
Dissertação apresentada ao Programa \\ de Pós Graduação em Educação da \\ Universidade de São Paulo, para a \\ obtenção do título de mestre em \\ Educação.
}

Área de concentração: Estado, Sociedade e Educação.

Orientadora: Prof. ${ }^{a}$ Dr. ${ }^{a}$ Dóris Accioly e Silva.

\section{SÃO PAULO}


Nome: Reis, lete Rodrigues

Título: Memória Social e Educação Rural no município de Atibaia SP (1964 - 1985): um estudo de caso

Dissertação apresentada à Faculdade de

Educação da Universidade de São Paulo para obtenção do título de Mestre em

Educação.

Aprovado em:

Banca Examinadora

Profa. Dra. _Dóris Accioly e Silva

Instituição: Faculdade de Educação - USP

Julgamento:

Assinatura:

Prof. Dra. Dulce C. A. Whitaker

Instituição: UNESP - Araraquara

Julgamento:

Assinatura:

Prof. Dra. Lúcia E. N. B. Bruno

Instituição: Faculdade de Educação - US

Julgamento:

Assinatura: 


\section{DEDICATÓRIA}

Aos estudantes das escolas rurais e do campo que resistem espalhadas pelo país afora. 



\section{AGRADECIMENTOS}

À minha orientadora Professora. Dóris Accioly e Silva, pela dedicação, carinho, auxílio e amizade, imprescindíveis para que eu pudesse realizar este trabalho.

Aos professores do curso de mestrado: Kátia Maria Abud Lopes, Lúcia Emília Nuevo Barreto Bruno, Max Bernard Butlen, Pere Solá-gussinyer, Rogério de Almeida e Romualdo Luiz Portela de Oliveira.

Ao professor Marcos Ferreira Santos que incentivou-me a retornar para a academia.

À professora Marisa P. Lajolo, amiga sempre generosa, pela disposição em ler o texto e encorajar-me a depositar esta dissertação.

À Professora Dulce Whitaker pelas preciosas sugestões, disponibilidade para ouvir-me, e pelo entusiasmo pelo tema escola rural.

Aos familiares, Oswaldo e Ivete pelo acolhimento em sua casa e pelas conversas regadas com vinho e amizade. Ivete, minha irmã e Ana Terra minha filha deram sugestões preciosas para colocar este trabalho de pé. José Carlos companheiro, desde sempre acompanhando e apoiando minha trajetória. Pedro e Maria Rita filhos queridos e Francisco, neto camponês/agricultor como ele gosta de ser tratado.

Aos funcionários da Secretaria de Pós-Graduação da Faculdade de Educação, pela atenção e compromisso com que sempre atenderam minhas solicitações.

Aos funcionários da Escola Estadual Profa. Zilah Barreto Pacitti, na pessoa de Clarice Leite que disponibilizou todo o acervo de documentos para consulta.

Aos ex-estudantes das escolas rurais de Atibaia que gentilmente nos concederam entrevistas, parte fundamental desta pesquisa. 
SUMÁRIO

\begin{tabular}{|l|c|}
\hline Resumo & 4 \\
\hline Abstract & 5 \\
\hline Introdução & 6 \\
\hline $\begin{array}{l}\text { CAPITULO 1. A relação entre uma história de vida e escolhas } \\
\text { profissionais e existenciais. Procedimentos teórico- } \\
\text { metodológicos. }\end{array}$ & 12 \\
\hline $\begin{array}{l}\text { Capítulo 2 - Quadro histórico social do Brasil: as transformações } \\
\text { ocorridas nos anos 1960, as reformas dos militares e a } \\
\text { repercussão no campo e na escola rural. }\end{array}$ & 32 \\
\hline $\begin{array}{l}\text { Capítulo 3. Universos contraditórios : A história oficial de Atibaia e } \\
\text { a memória social. }\end{array}$ & 55 \\
\hline $\begin{array}{l}\text { CAPITULO 4. Documentos e depoimentos: história e memória da } \\
\text { escola e dos estudantes: Convergências e divergências. }\end{array}$ & 74 \\
\hline Considerações finais & 101 \\
\hline Referências bibliográficas. & \\
\hline
\end{tabular}




\section{RESUMO}

O tema desta pesquisa é a escola rural e o problema da escolarização de crianças de Atibaia, estado de São Paulo. O período estudado tem como marco inicial o ano de 1964, quando ocorreu o Golpe Militar até 1985 ano que marcou o início da nova redemocratização brasileira.

Foi realizado um estudo da escolarização de crianças em escolas rurais, enfatizando os papéis integrador e socializador da escola junto aos filhos dos trabalhadores nascidos na região, além de migrantes que se estabeleceram em dois bairros rurais de Atibaia, Portão e Água Espraiada.

Abordam- se as diferenças existentes na população rural, tanto em relação às condições materiais de vida, quanto à produção dos bens simbólicos, papéis anteriormente contemplados pela escola.

Para compreender esse processo, optou-se metodologicamente pelas técnicas da História Oral, entrelaçadas aos estudos da memória, enquanto fenômeno social. Através da realização de entrevistas semi estruturadas, foram coletadas informações que contribuíram para a compreensão da complexidade das questões que envolvem o campo brasileiro e a educação escolar de sua população.

PALAVRAS CHAVE: Escola Rural, Escolarização, História Oral. 


\section{ABSTRACT}

The theme of this research is the rural school and the problem of access and education of childrens from Atibaia, State of Sao Paulo. The study period is from 1964, when there was the military coup, to 1985, marked by the beginning of Brazilian democracy.

The study focused on rural schools and their integrating and socialing role in the education of workers and migrants families located in two rural districts of Atibaia, Portão and Água Espraiada neighborhoods.

To understand this process, the oral history methodology was chosen, and memory studies as a social phenomenon. By carrying out semi-structured interviews, information was collected that contributed to the understanding of the complexity of the issues surrounding the Brazilian countryside and the education of its population.

KEYWORDS: Rural School, Schooling, Oral History. 


\section{Introdução}

Este estudo surgiu da necessidade de compreender a educação praticada nas escolas rurais de Atibaia e especificamente nas escolas do Bairro do Portão e da Água Espraiada, numa ótica diferente de algumas pesquisas que se centram nas questões pedagógicas ou administrativas e que não levam em conta o estudante e suas especificidades de origem social e cultural, somadas à condição de morador da zona rural.

O objetivo dessa dissertação é compreender as experiências e a construção do conhecimento nas e sobre as escolas rurais, atentando para as diferenças entre história oficial e memória social, esta última implicando a questão das diferenças culturais no período de 1964 a 1985.

A periodização desta pesquisa situa-se no contexto das transformações sociais ocorridas no Brasil e no Estado de São Paulo, após o golpe militar de 1964 até o final da ditadura e início da chamada Nova República (1985). Realizou-se um recorte, tanto do ponto de vista temporal como também espacial - a educação rural no município de Atibaia, no emaranhado processo histórico da escolarização que se desenvolveu no Brasil durante o período.

Acredita-se que uma possível contribuição desta pesquisa é ajudar no mapeamento de experiências vividas por ex-alunos das escolas rurais que não foram registradas em documentos escritos. Considerando que a educação escolar dominante é burocrática e legalista, faz-se necessário aprender com a população que frequentou a escola rural e com ela elaborar um novo conhecimento sobre a educação rural, conforme apontou Whitaker (2002).

Este trabalho nasceu do longo convívio com as populações rurais, sua riqueza cultural, seu modo de viver e relacionar-se com o meio ambiente. Estas dimensões têm sido profundamente alteradas à medida que avançaram as relações capitalistas no campo em nosso país, portanto um objetivo implícito na pesquisa é buscar as conexões entre escola rural, sociabilidade, práticas culturais, meio ambiente e memória.

Comecei a dar aulas na periferia de São Paulo, na Vila Brasilândia em pleno governo Maluf (1978-79), vivi a real situação do ensino público: não havia água, não 
havia merenda e nas salas de aulas as lousas danificadas impediam que fizéssemos anotações, mesmo que levássemos giz. Numa classe de quinta série com 54 crianças eu tentava dar aulas. Levava uma caixa de livros, cadernos e algum material escolar. Contava histórias do país, da cidade de São Paulo e do passado. Procurava ajudar os alunos a imaginar como deveria ser a vida em outras épocas. Eles se interessavam e gostavam também de narrar suas próprias vidas e as de suas famílias. Contavam histórias que ouviam dos pais e avós, cuja maioria havia vivido em regiões rurais.

Mais tarde, no ano de 1983, fui dar aulas em uma escola rural em Atibaia, época em que desenvolvi o interesse pelo conhecimento mais profundo da realidade educacional no meio rural em um passado recente. $O$ contato com as crianças que viviam no mundo rural somou-se à minha própria experiência como aluna de uma escola que já não mais existe. Foi fechada como centenas de outras, em decorrência das sucessivas reformas educacionais e das transformações decorrentes do modelo de desenvolvimento econômico do país, sobretudo a urbanização. Esses fatos evidenciaram a necessidade de registrar essa história, antes que de todo desaparecesse.

Com pouca experiência como professora de alunado muito diferente daquele com o qual havia trabalhado na capital, tive dificuldade em adaptar-me à escola rural, o que me levou a resgatar as memórias de infância e do meu processo inicial de escolarização. Depois de cometer muitos erros e fazer exigências que as crianças e suas famílias não tinham como cumprir, comecei a ver em cada uma delas a menina que fui e também os meus antigos companheiros de escola rural. Tive consciência da seletividade da escola e compreendi que teria um papel a desempenhar para não contribuir para o fracasso de tantas crianças.

Foi um tempo de muitos estudos e reflexões para entender o funcionamento da escola e melhorar a prática em sala de aula. Vasculhando armários encontrei uma publicação da Secretaria de Estado da Educação de São Paulo do ano de 1983. Era uma pesquisa feita pela Coordenadoria de Estudos e Normas Pedagógicas (CENP) e Fundação de Estudos Agrários Luiz de Queiroz, intitulada Escolarização no Meio Rural - Condições socioeconômicas e pedagógicas do seu desenvolvimento, organizada pela Professora Maria Ignez Guerra Molina. 
Este documento apresenta importante estudo sobre a situação do Ensino do então 1‥ Grau na zona rural no estado de São Paulo. O trabalho é constituído de duas partes. A primeira, teórica, enfatiza a problemática que envolve a escola rural, focaliza a crise da escola e as modificações que ocorreram no setor agrícola do estado de São Paulo. A segunda parte, que contém a análise dos dados empíricos selecionados nas Diretorias Regionais de Ensino de todo o Estado de São Paulo, oferece um panorama geral dos tipos de escolas existentes e em funcionamento durante os dois anos da pesquisa, 1980 e 1981, a saber: Escolas de Emergência, Escolas Isoladas, Escolas Agrupadas e Escolas Estaduais de 1ํ. Grau.

Tal pesquisa foi importante para mapear a situação das escolas. Embora não contemplasse nenhuma análise dos problemas das escolas rurais, ao menos mostrava que o governo tinha algum interesse no assunto. Importante salientar que o estudo citado foi feito durante o governo de Franco Montoro, momento muito significativo para a educação paulista. Nós, educadores, estávamos mobilizados e esperançosos, lutando fortemente em prol da escola pública. O tema da resistência contra a ditadura e as bandeiras levantadas no contexto da luta pela redemocratização do país e pelo ensino público e gratuito para todos, será tratado no próximo capítulo desta dissertação no sentido de contextualizar historicamente a pesquisa.

Evento muito significativo e que provocou novo ânimo no debate sobre a escola rural foi o Fórum de Educação do Estado de São Paulo Sobre a Escola Pública Rural, ocorrido em 1984. A partir das ideias que circularam no evento, tais como funcionamento das escolas rurais, repetência, evasão escolar, formação de professores, características físicas e pedagógicas das escolas, situação do alunado e da comunidade, financiamento e gestão, entre outros, surgiram ações e políticas públicas para a educação rural.

De posse dessas informações e de outras leituras, cresceu em mim a motivação para me aprofundar nos estudos sobre educação rural. Soma-se a esses fatores a prática como professora, diretora, e, posteriormente, supervisora por cinco anos das escolas rurais do município de Atibaia, Vargem e Nazaré Paulista, que me permitiu acompanhar e vivenciar as tentativas de reformas da educação rural. 
Em 1986, ingressei como professora efetiva de História mediante aprovação em concurso, na escola "Professora Zilah Barreto Pacitti", onde antes já lecionava como ACT (Admitida em Caráter Temporário). Localizada no centro de um bairro que ainda guarda traços do seu passado rural, embora apresente características do processo de urbanização acelerada que caracteriza a região, principalmente após os anos de 1980, a escola recebia alunos egressos de escolas rurais isoladas, como eram denominadas na época.

Esses meninos e meninas tinham dificuldades de adaptação ao regime seriado da segunda etapa do ensino de primeiro grau (hoje Ciclo II do ensino fundamental), que consistia em professores e livros didáticos específicos para cada matéria ou série. Haviam estudado em classes multisseriadas, com um único professor para ministrar todas as matérias, em escolas distantes de suas residências, e que funcionavam de forma precária.

A partir de 1991 passei a exercer o cargo de assistente de direção e, no ano seguinte, assumi a direção, confiante na influência que o diretor teria no processo de melhoria do funcionamento da escola, no projeto pedagógico e, sobretudo, na aprendizagem dos alunos.

Em 1994, participei de um seminário promovido pela Fundação para o Desenvolvimento da Educação, da Secretaria Estadual de Educação do Estado de São Paulo. Esse seminário era parte das ações do Programa de Aperfeiçoamento de Recursos Humanos da Educação, cujo objetivo era a elevação da qualidade das escolas públicas. Nessa ocasião entrei em contato com reflexões teóricas sobre as diferentes faces da violência, bem como da violação dos direitos à educação assegurados pela Constituição Federal e pelo Estatuto da Criança e Adolescente. Foi fundamental à época, para aumentar minhas inquietações, o texto Escola, violência e trabalho infantil no Brasil (Whitaker, 1994). Ao lê-lo e relê-lo por inúmeras vezes, tive a sensação de ter encontrado o fio da intrincada meada teórica e prática em que me encontrava para pensar a escola rural.

As memórias da autora, aqui apresentadas, buscam resgatar sua trajetória enquanto agente da educação rural em diversos papéis: como aluna, na infância; professora; diretora; supervisora; e, mais recentemente, secretária da educação do município de Atibaia. Os fatos se entrelaçam e mostram como nessa jornada a educação rural constituiu os modos de interpretação social, o pensar histórico e o 
engajamento profissional da pesquisadora no campo da educação. As vivências teórica e prática conduziram ao tema e ao problema da pesquisa para os quais se pretende trazer alguma luz.

O primeiro capítulo esclarece os procedimentos teórico- metodológicos adotados, apresentando o problema da pesquisa e suas justificativas. Ainda neste capítulo definiram-se os conceitos de fundo e os conceitos âncoras que permeiam a discussão proposta neste estudo, tais como cultura, violência simbólica, habitus, trajetória, opressão, libertação, educação rural e o recente debate acerca da educação do campo. Além disso apresenta-se uma pesquisa bibliográfica sobre à educação rural, restrita à Universidade de São Paulo. Escolhemos trabalhar com autores que fazem uma análise crítica do sistema educacional, do ponto de vista dos interesses dos trabalhadores, porém sem cair em armadilhas ortodoxas ou esquemáticas de análise bem como autores que nos fizessem avançar na compreensão do sistema educacional e do processo de escolarização de crianças e jovens que vivem na zona rural.

O segundo capítulo discorre acerca do quadro histórico-social da educação rural no Brasil após 1964. Foi dividido em três partes, pois houve necessidade de se fazer um recuo temporal para propiciar ao leitor melhor contextualização dos acontecimentos que antecederam o Golpe Militar, das transformações ocorridas durante a ditadura e o período posterior da democratização do país. Para tanto, é feita uma incursão no campo das transformações na legislação que amparou as reformas na política educacional do país e sobretudo, na educação rural no estado de São Paulo.

Os capítulos três e quatro tratam do objeto e dos sujeitos do estudo, respectivamente. Assim, o capítulo três é dedicado à história do lugar, o município de Atibaia, desde sua fundação no século XVI, a formação dos bairros rurais onde foram instaladas as escolas escolhidas para o estudo até as transformações ocorridas com a urbanização. Foi dada ênfase ao cotidiano social, político e econômico do município e também à importância que representou a educação para os moradores de Atibaia.

No capítulo quatro, abordamos a formação histórica dos Bairros, situando também a história das escolas, foram analisadas fontes secundárias, tais como o livro de registros e fontes primárias, nucleares nesta pesquisa. Essas foram criadas com base nos depoimentos colhidos nas entrevistas que foram realizadas com ex- 
estudantes das escolas públicas rurais, resultando um texto permeado pela análise das falas no contexto das mudanças ocorridas na política educacional.

Por fim são apontadas as contradições que se expressam entre o discurso oficial e o que ocorreu na prática para o desenvolvimento das escolas rurais. Enfatizou-se também a instalação da burocracia e do controle sobre as escolas, o processo de escolarização e a trajetória de vida dos ex-estudantes. 


\section{CAPÍTULO 1. A relação entre uma história de vida e escolhas profissionais e existenciais. Procedimentos teórico-metodológicos}

$\mathrm{Na}$ década de 1980 havia, entre os responsáveis pela política educacional e dos órgãos da administração do sistema e mesmo entre boa parte dos educadores, o entendimento de que o fracasso escolar era decorrente de fatores externos ao funcionamento da escola. O debate então em voga versava acerca de qual escola oferecer às crianças e jovens das camadas pobres, que viviam na periferia das cidades.

Assim, programas como o da merenda escolar, de aquisição de material didático, manutenção das escolas, transporte de estudantes entre outros, tornaramse cada vez mais centrais na administração da educação. Essa política compensatória, ao lado da mobilização em torno do aumento do número de vagas, da garantia de acesso a todos e de uma escola democrática que servisse aos interesses da classe trabalhadora, entre outras, passaram a fazer parte da agenda de reivindicações da população e dos sindicatos dos educadores, em fase de reconstrução.

Em paralelo ao movimento popular em defesa da escola pública, o debate teórico, levado a cabo na universidade e nos cursos de formação oferecidos pelo governo do Estado de São Paulo, tinha como referência autores como Paulo Freire, Louis Althusser, Pierre Bourdieu e Jean Claude Passeron, que deixaram marcas em toda uma geração de educadores.

Esse campo teórico articulado com o enfrentamento das contradições da prática no cotidiano da escola pública rural fez surgir questionamentos que resultaram na elaboração do projeto de pesquisa que foi apresentado no processo seletivo para o curso de mestrado. Deu-se início a uma trajetória de pesquisa, na qual se buscou aliar a prática ao conhecimento teórico proporcionado pela academia.

Definido o objeto de estudo - a escola rural no Estado de São Paulo surgiram questões mais amplas para a compreensão da totalidade do problema da escolarização das crianças e jovens na zona rural, tais como: 1) a aceleração do 
processo de urbanização, o êxodo rural e o declínio do sistema tradicional de produção no quadro das transformações capitalistas no Brasil, principalmente após os anos 60; 2) as contradições que envolvem a prática escolar em nosso país; 3) o papel da educação para um projeto de transformação social; 4) o evidente descompasso entre a escola e as necessidades dos estudantes, principalmente na zona rural e 5) a questão da diversidade cultural da população rural e as dificuldades enfrentadas ao frequentar a escola. Essa pesquisa não tem qualquer ambição de abarcar a complexidade envolvida em tais questões, mas é necessário tê-las como orientadoras no processo de síntese e de construção do conhecimento.

O trabalho de José de Souza Martins (1971), já apontava os limites dos estudos de sociologia da educação, que a despeito da sua importância, lograram focalizar temas como a estrutura e a função da escola, a situação do ensino, a ideologia do educador, o rendimento escolar, as funções inovadoras do ensino, a formação de mão-de-obra. Esses temas foram privilegiados pelos pesquisadores dado o contexto histórico e o desenvolvimentismo, que estimulou reflexões que procuraram situar os obstáculos às funções criadoras da escola.

Martins (1971), buscou então pesquisar os agentes da escolarização, analisando o teor das representações dos sujeitos da escolarização, não ao nível da instituição escolar, mas sim ao nível da situação socioeconômica. O autor entendia por sujeito não só os alunos, mas também as pessoas para as quais a escolarização é outra parte do seu próprio projeto de vida. Realizou entrevistas em três regiões do estado, sendo Alta Sorocabana, Baixa Mogiana e Alto Paraíba, escolhidas a partir da combinação de dados estatísticos sobre grau de utilização de tecnologia modernas na produção de matéria-prima para a indústria, tecnologia em transição e produto de exportação, tecnologia tradicional.

O resultado da pesquisa realizada por Martins (1971) mostrou a distinção entre a escolarização de nível primário no meio urbano e no meio rural. No primeiro caso, a escola é vista como um meio de ascensão social. Na zona rural, é mais um trabalho que se soma àquele do campo. Ainda que este estudo reproduza a lógica dualista, contrapondo o rural e o urbano, mostra as alternativas extremas que são reproduzidas para a criança, sob forma de opção sua e ou de sua família, a situação de classe, os limites sociais de sua mobilidade presente e futura, e o desenrolar da 
sua biografia. No meio rural, a concomitância da escolarização com o trabalho produtivo é imposta pelas condições de existência e reflexo das representações de um modo de vida.

A experiência nas escolas onde atuei reforça a ideia de escolarização como um trabalho em si mesmo e o valor da educação que, segundo a crença da população, somente a escola pode oferecer tal como apontou Brandão (1990). As crianças, jovens e suas famílias faziam um esforço muito grande para a preservação e melhoria das escolas, ajudavam no que podiam: pintura, consertos em geral, capina do mato, limpeza e outros serviços. No que se refere ao acompanhamento da vida escolar das crianças cuidavam para que não faltassem às aulas e respeitassem os professores. Mesmo as crianças retidas por vários anos na mesma série continuavam a frequentar a escola, embora permanecessem analfabetos ou com baixos níveis de aprendizagem, o que evidencia uma das contradições presentes na escola rural.

Cabe discutir, ainda, a vitimização das crianças e jovens de zero até 18 anos, principalmente, diante do despreparo estrutural e pedagógico ofertado pelas instituições que assumem, mal e de forma insuficiente, o papel que legalmente é do Estado, como afirma o Estatuto da Criança e do Adolescente, em seu Capítulo IV: "Art. 54. É dever de o Estado assegurar à criança e ao adolescente: (...) IV atendimento em creche e pré-escola às crianças de 0 a 6 anos de idade" (BRASIL, 1990, p. 36).

Há também que se analisar o déficit educacional vivenciado por toda uma geração: à medida que não se proporciona o acesso à educação infantil de qualidade, perde-se a oportunidade de que estas crianças ingressem mais preparadas no ensino fundamental. Assim, as crianças das camadas mais pobres da população, ao entrarem em níveis mais elevados da escolaridade, encontram dificuldades de toda ordem, sejam estas de aquisição dos códigos socialmente valorizados pela escola e professores, sejam da ordem de aprendizagem e assimilação de conteúdos valorizados no mundo do trabalho e na sociedade em geral.

Estudiosos dessas questões, principalmente psicólogos e pedagogos, têm se dedicado nas últimas décadas a estudos que tentam explicar as disparidades no 
desempenho escolar entre os integrantes de grupos sociais em termos de diferenças individuais, de personalidade, de rendimento intelectual, de habilidades perceptivomotoras ou de acordo com diferenças grupais, culturais, étnicas, etc. Isso gerou um corpo de conhecimentos identificado e disseminado nos meios escolares como a teoria da carência cultural.

Essa teoria começou a delinear-se nos Estados Unidos, no final da década de 50 e no começo da década de 60 , momento em que as minorias raciais norteamericanas começavam a denunciar que em um país que se dizia democrático e promotor da igualdade de oportunidades, essa igualdade, na verdade, não acontecia. (PATTO,1990). Esse movimento teve influência importante no Brasil, não só no âmbito acadêmico como também nos movimentos de mobilização social contra a ditadura militar, a favor da anistia, da volta dos exilados, movimento pró educação pública e gratuita, entre outros. No final da década de 1970 muitos professores retornaram de seus cursos de formação em universidades norteamericanas e disseminou-se aqui a teoria da carência cultural, que veio a se constituir em ideologia que ainda hoje está presente nas representações que alguns educadores fazem da criança e do jovem brasileiro.

É importante assinalar conforme Patto (1990), que esse foi o primeiro momento da explicação da questão da baixa aprendizagem e altos índices de abandono escolar nos meios populares: a criança pobre não aprendia porque era portadora de atraso no desenvolvimento psicomotor, perceptivo, lingüístico, cognitivo, emocional entre outros. Configura-se assim, no pensamento educacional, primeiro nos Estados Unidos e depois em todos os países que importaram esses conhecimentos, entre eles o Brasil, a concepção de que estamos diante de carentes ou deficientes culturais.

Na década de 1980, num segundo momento da produção de conhecimentos na área de aprendizagem das crianças pobres, os projetos de pesquisa foram focados na compreensão da diferença cultural. A criança pobre deixa de ser considerada carente ou deficiente e sim diferente da criança das classes médias e alta.

Neste patamar das pesquisas, as causas das dificuldades de aprendizagem e consequente abandono escolar foram buscadas no interior das escolas e no 
processo educativo, o que colocou em evidência a inadequação da política educacional, da legislação, sobretudo os efeitos da Lei 5692/71 (elaborada e posta em prática durante o governo dos militares), a precária situação do professorado, tanto em termos de formação acadêmica como também de valorização profissional, condições de trabalho e precariedade das escolas públicas, além das vicissitudes da tecno-burocracia que se instalou no sistema educacional.

O terceiro momento, ainda na década de 1980, da teoria da carência foi marcado pela pesquisa sobre as práticas escolares na produção do fracasso escolar das crianças e jovens pobres das escolas públicas, tendo como centro de análise a instituição escolar. Não se tratou, porém, de encontrar um novo culpado. Se antes este era a criança e sua família, nesse momento não se tratou de culpar o professor. Procurou-se compreender o espaço onde se desenvolvia o trabalho escolar: as condições de trabalho e de formação dos professores, a qualidade das relações na escola e na sala de aula, não só do ponto de vista pedagógico, mas também das relações sociais entre a escola e a comunidade.

A ideologia da carência servia como justificativa para o descaso com as escolas e a precariedade das condições de trabalho. Haveria uma falta de interesse das famílias e dos próprios estudantes que levariam ao fracasso escolar manifesto pelos índices de repetência e evasão escolar. Conforme apontou Freitas (2005), em que pesem os dados estatísticos do sistema educacional, podemos desconfiar que a própria estrutura da escola produziu o fracasso e que o aluno pobre, desnutrido e que não aprende teria sido uma invenção da sociedade moderna e capitalista.

Essas crianças e jovens pobres eram portadores de carências diversas que passaram a ter rubricas nos orçamentos e planos governamentais de intervenção nas camadas mais pobres da população. Nesse campo ideológico, a escola era apresentada como uma instituição reformadora da sociedade que visava corrigir os desvios. No entanto, produziu-se o oposto: um massivo subdesenvolvimento e empobrecimento e também uma incalculável exploração e opressão que são reflexos de um sistema educacional que, no limite, atua fora da realidade social do país, em constante transformação. (FREITAS, 2005, p. 21).

Chegando ao final destas memórias, marcadas por uma inquietação que me acompanha até hoje, retorno às perguntas iniciais, num novo contexto histórico, em 
que a ideologia reformadora da sociedade através da educação e da escola foi atropelada por diferentes e novos problemas surgidos com o avanço do capitalismo neoliberal e a resistência popular às suas investidas.

Surgem novas ideologias e novos sujeitos, organizados ou não nos movimentos sociais, e com eles novas perguntas. O que fica desse memorial, percurso intelectual e prática na educação é que embora, de forma preliminar, podemos dizer que a ideologia reformadora da escola cumpriu o seu papel histórico, atrelando a educação às demandas de desenvolvimento econômico capitalista do país, mas nem sempre funcionando como um instrumento de emancipação da classe trabalhadora.

\subsection{0 problema da pesquisa}

A forma como a educação foi conduzida no Brasil ao longo da história, nos trouxe a um ponto em que a relação entre escola, vida prática e projeto de país se apresenta ainda com muitas distorções, precariedades e injustiças. A partir dos anos 1950, o modelo econômico adotado com vistas à industrialização gerou demandas para a educação que não foram sanadas pela falta de um planejamento adequado, indispensável para cumprir o dever de bem educar a população. Isso gerou uma crise de identidade na educação praticada em nossas escolas, que foi se agravando ao longo dos anos.

Ao analisar a evolução do ensino desde o período colonial até a década de 1970, Romanelli (1984) identifica os determinantes econômicos e sociais que configuraram a educação escolar no Brasil: uma educação destinada à formação da elite para o exercício do poder e completo menosprezo pela escolarização básica da maioria pobre. Da leitura desta autora, podemos deduzir que a organização e modernização da estrutura de ensino e a busca de uma melhor eficiência do sistema estão diretamente ligadas às necessidades do modelo econômico, articuladas com as estruturas do poder político e sua composição de forças, cujos grupos hegemônicos têm atuação e responsabilidade direta na organização formal do sistema de ensino. Essa organização se dá, historicamente, de forma altamente 
centralizada, revelando os estreitos limites do poder político local e mais ainda os limites de atuação da população como um todo e dos educadores de forma geral.

No que tange à educação rural, em artigo publicado na revista Educação e Pesquisa, Damasceno e Beserra (2004), com o objetivo de esboçar o "estado da arte" neste campo de investigação, mapeiam e discutem o conhecimento produzido nas décadas de 80 e 90, na Universidade de São Paulo. A pesquisa bibliográfica foi feita pelos autores no banco de resumos de dissertações e teses da ANPED, nos periódicos acadêmicos nacionais e regionais, como a Revista Educação e Pesquisa da Faculdade de Educação da USP, além dos principais livros enfocando a temática da educação rural publicados no período.

Os resultados são sintomáticos e comprovam a marginalidade do estudo do tema: de um total de 8.226 pesquisas feitas no período, apenas $(1,2 \%)$, se dedicaram ao estudo da educação rural. No quadro da produção científica por instituição, a pesquisa aponta que na USP não foi efetuada nenhuma dissertação e apenas cinco teses de doutorado sobre a temática, durante as duas décadas estudadas (DAMASCENO e BESERRA, p.76-84, 2004).

As autoras apontam que, dentro da relativa escassez que caracteriza os estudos no campo da Educação Rural, há certa abundância de estudos que mostram a precariedade das condições físicas e intelectuais das escolas rurais. Elas propõem que seja criado um programa de ação afirmativa para esta área de estudos e a necessidade de que as agências fomentadoras, bem como o Ministério da Educação, abram concursos ou programas específicos sobre a Educação Rural, com incentivo especial aos estudantes e pesquisadores que escolhessem enfrentar tal temática. Propõem, ainda que sejam feitos estudos mais abrangentes, que incluam dados quantitativos e qualitativos, e, considerando a extrema diversidade do campo brasileiro, estudos etnográficos que ofereçam elementos para uma ação educacional mais eficaz do Estado e dos movimentos sociais. (DAMASCENO e BESERRA, p.76-84, 2004).

$\mathrm{Na}$ pesquisa aqui realizada, o processo educacional buscará ser compreendido a partir do ponto de vista daqueles que receberam a educação rural que Ihes foi oferecida. Assume-se que "a evolução do sistema educacional, a expansão do ensino e os rumos que esta tomou podem ser compreendidos a partir 
da realidade concreta criada pela nossa herança cultural, evolução econômica e estruturação do poder político" (ROMANELLI, 1984, p. 19).

Não se trata aqui de adotar um esquema teórico ortodoxo ou rígido, mas sim apoiar de forma metodológica os conceitos que fundamentam esta pesquisa, conforme nos ensinou Paulo Freire:

(...)fala-se da crise da escola como se ela existisse desgarrada do contexto histórico, social, econômico, político, da sociedade concreta onde atua (...). Enquanto categoria abstrata, instituição em si, portadora de uma natureza imutável da qual se diga é boa, é má, a escola não existe. Enquanto espaço social em que a educação formal, que não é toda a educação, se dá, a escola não é, a escola está sendo historicamente. A compreensão do seu estar sendo, porém, não pode ser lograda fora da compreensão de algo mais abrangente que ela - a sociedade mesma na qual se acha (FREIRE, p.21, 1983).

Ao definir o problema da escolarização da população rural como objeto, concordo com Demartini (1979),que defende que essa linha de estudo seja considerada como um item a parte na problematização da educação geral no Brasil. Esta autora nos alertou para o fato de que não se trata de dar tratamento privilegiado à educação escolar rural pelas possíveis diferenças em relação ao meio urbano, mas sim pela forma como administradores e planejadores da política educacional geral, ou mesmo sociólogos, têm considerado a questão, ou seja, como um aspecto secundário com relação aos debates dos problemas educacionais.

O tratamento marginal dado ao tema da educação rural demonstra a ideologia que sustenta a subordinação do meio rural e da educação de sua população em relação ao meio urbano e à educação oferecida à população das cidades, como se essa fosse de melhor qualidade que aquela oferecida nas escolas rurais. (DEMARTINI, 1979, p.10).

Demartini (1979) apontou que o posicionamento de alguns pesquisadores e planejadores, ao abordarem o problema de forma equivocada e sem o necessário questionamento teórico, leva, muitas vezes, ao fechamento de escolas rurais, que atendem parcela considerável da população brasileira. Seus estudantes são transferidos para escolas urbanas, causando grandes transtornos como por exemplo, no processo de aprendizagem das crianças e jovens e também na vida das famílias que vivem no meio rural, se configurando como mais um motivo para a migração para as cidades. 


\subsection{Procedimentos teórico- metodológicos}

Existem diferentes modos de entender a realidade, como também há diferentes posições metodológicas que explicitam a construção do objeto de estudo. Ao apresentar a metodologia que compõe a pesquisa, incluem-se as concepções teóricas e o conjunto de técnicas definidas para alcançar respostas ao objeto de estudo proposto. É a metodologia que explicita as opções teóricas fundamentais, que expõe as implicações do caminho escolhido para compreender determinada realidade e o sujeito em relação com ela. (MINAYO,1994, p. 22).

A pesquisa qualitativa ocupa espaço privilegiado nos estudos sociais, na medida em que possibilita a produção de um novo tipo de conhecimento. A investigação das relações sociais estabelecidas por seres humanos - que possuem uma historicidade, crenças e valores - é o campo de atuação da pesquisa social. Por isso, nesta abordagem, todos os sujeitos participantes, seja investigador e investigado, influenciam na construção do conhecimento. Minayo (2010, p. 12) pontua que:o objeto de estudo das ciências sociais é histórico. Isto significa que cada sociedade humana existe e se constrói num determinado espaço e se organiza de forma particular e diferente de outras. Por sua vez, todas as que vivenciam a mesma época histórica tem alguns traços comuns, dado o fato de que vivemos num mundo marcado pelo influxo das comunicações. Igualmente, as sociedades vivem o presente marcado por seu passado e é com tais determinações que constroem seu futuro, numa dialética constante entre o que está dado e o que será fruto de seu protagonismo.

A pesquisa social atende às exigências da complexidade do contexto educacional, que requer a utilização de um método capaz de contemplar as novas demandas educativas.

Dentre as técnicas qualitativas, Whitaker e Veloso (2005), observam que cresce no mundo todo, o interesse pela oralidade e pela memória individual como fontes inesgotáveis de dados que nos auxiliam na compreensão da história e do indivíduo enquanto sujeito histórico-social. Assim, recorreu-se à metodologia da história oral e dos estudos da memória, pois este procedimento, além de dar voz aos estudantes, poderá ajudar a encontrar respostas para algumas questões pendentes nas pesquisas sobre educação rural. Para tanto, não trataremos de pesquisar sobre, mas sim pesquisar com os ex-estudantes, a fim de resgatar suas experiências 
educacionais e percepções sobre o viver em região rural, nas franjas do rural-urbano em determinada época, como compreende Whitaker (1984).

Buscou-se romper com uma ótica de estudo que contribuiu para a desqualificação do modo de vida da população pobre em geral, e rural em particular.

O modelo educacional vigente em nosso país, desde remotos tempos, tem servido mais para a subordinação ao modo de vida capitalista do que para uma socialização que respeite as diferenças sem transformá-las em justificativas da desigualdade.

\subsubsection{Método e trabalho de campo.}

Para as finalidades desta pesquisa optou-se por uma pesquisa de campo baseada nas técnicas da História Oral, entrelaçadas ao estudo da memória, enquanto fenômeno social, tal como a tratou Accioly e Silva (1995), inspirada nas teorias de Maurice Halbwachs e Jacques Le Goff.

Accioly e Silva (1995) aponta que, entre os diferentes métodos da História Oral, as histórias de vida, as biografias, os depoimentos pessoais e as entrevistas têm sido novamente utilizados nas Ciências Sociais e que dentre eles, a entrevista é a forma mais antiga de coleta de dados orais.

No caso dos depoimentos pessoais, ao pesquisador interessam apenas os acontecimentos da vida do narrador que se ligam ao tema e ao período estudados. A entrevista, mesmo longa e aberta, (sem questionário), pode se esgotar num só encontro, ao contrário das histórias de vida. Na verdade, dada a não compartimentação da memória humana, os depoimentos pessoais podem extravasar o momento estudado. Por isto criamos um termo que dá a idéia de uma continuidade, ainda que limitada, aos depoimentos pessoais: depoimentos ressonantes. Este termo também nos remete à inseparabilidade entre projeto e memória como atributos essenciais da condição humana. (ACCIOLY e SILVA, 1995, p. 7).

A memória, por ser considerada um atributo da condição humana, representa o direito de a pessoa ter um passado, conhecer sua história e seu enraizamento. A seletividade da memória decorre igualmente das situações presentes, das transformações e escolhas possíveis operadas no decorrer dos trajetos pessoais: "Não há evocação sem uma inteligência do presente. Um homem não sabe o que ele é se não for capaz de sair das determinações atuais". (BOSI, 1979, p.39). 
Para este estudo, trato da memória nas várias perspectivas trazidas por Accioly e Silva (1995), e autores nos quais ela se ampara. A memória é constituída nas relações sociais, fruto da socialização através da primeira das instituições sociais que é a linguagem. Ao lado disso, tomamos a memória coletiva não apenas como uma conquista, mas como "um instrumento e um objeto de poder". (LE GOFF; 1992).

Os dados foram levantados por meio de entrevistas junto à ex-alunos da escola, tema deste estudo. A técnica da entrevista foi considerada mais reveladora que dados secundários, tais como os obtidos nos livros de registro das ocorrências nas escolas rurais e os relatórios de visita da direção e supervisão, pois pelo que se pode notar, são feitos para formalizar o funcionamento da escola e atender as necessidades da burocracia e do planejamento estatal, não refletindo os aspectos socioculturais inerentes à realidade escolar e social.

Considerou-se que a entrevista em história oral não deve limitar-se apenas aos objetivos da pesquisa e estar a serviço do entrevistador. $O$ foco deve ser 0 entrevistado, e ele ou ela deve fazer mais do que falar ao responder as perguntas ocasionais do entrevistador, que deve esclarecer que não se busca respostas do tipo sim e não, mas posicionamentos pessoais, julgamentos e explicações sobre as experiências vividas.

Conforme Queiroz (1991), uma das técnicas mais fascinantes da pesquisa sociológica são os depoimentos pessoais. A autora afirma que a formulação prévia das questões é uma das regras mais importantes na coleta de informações e que estas orientarão as fases seguintes da pesquisa. Assim quanto maior a familiaridade do pesquisador com o grupo em análise, maior a facilidade para a formulação da questão.

A conduta do pesquisador, sobretudo quando ele fizer parte do grupo deve ser ética, cabendo a ele fazer uma análise pessoal por meio de um depoimento honesto, em que sejam expostas sua própria opinião e experiências, como também as opiniões e experiências das outras pessoas. O melhor conhecimento de si mesmo dá maior objetividade para a pesquisa em vista e, o depoimento do próprio pesquisador enriquecerá o acervo dos dados sobre o problema que estuda. (QUEIROZ, 1991).

Lüdke e André (1986), na mesma direção, atentam para o caráter de interação que permeia a entrevista e a atmosfera de influência recíproca entre quem 
pergunta e quem responde. Especialmente nas entrevistas não totalmente estruturadas, o entrevistado discorre sobre o tema proposto com base nas informações que ele detém e que no fundo é a razão de ser da entrevista. Assim, o tipo de entrevista mais adequado para o trabalho de pesquisa em educação é a entrevista menos estruturada, que possibilita ao informante maior liberdade e flexibilidade para fornecer as informações que se quer buscar. (LÜDKE e ANDRÉ, 1986).

Nesse ambiente metodológico é que foram feitas as entrevistas. Foram entrevistados ex-alunos da extinta Escola do Bairro da Água Espraiada e da Escola Estadual Professora Zilah Barreto Pacitti, situadas no município de Atibaia, estado de São Paulo. A seleção dos entrevistados foi feita com os critérios idade, data do ingresso na escola e nível de escolaridade alcançado. Tendo como referência os objetivos desta pesquisa, foi elaborado um roteiro para a coleta dos depoimentos e não um questionário com perguntas fechadas. Este procedimento foi escolhido por possibilitar ao informante maior liberdade e flexibilidade para fornecer as informações que se quer buscar.

O roteiro foi elaborado para apreender especificamente as relações entre a escola e os segmentos da população pobre, buscando saber que tipo de escola foi oferecida a essa população e quais as lembranças mais marcantes no percurso escolar que fizeram. O recurso utilizado foi a gravação das falas dos entrevistados e a transcrição das entrevistas. Houve preocupação em deixar as pessoas livres e bem à vontade para lembrarem-se do seu passado de estudante, por isso, neste momento inicial, os entrevistados foram consultados a respeito da revelação de suas identidades e das informações prestadas, com o que concordaram.

Para começar a pesquisa de campo e testar o instrumento de coleta de dados, escolhi de forma proposital duas pessoas de idade aproximada, que frequentaram a mesma escola na mesma época, e depois em época diferente como é o caso de Luiza que concluiu o ensino fundamental no Tele curso, em período bem recente. As duas entrevistadas vivenciaram as mudanças ocorridas nos bairros, provocadas pelo processo acelerado de urbanização e também as mudanças ocorridas na escola nesse período, pródigo em mudanças na legislação.

Foi elaborado o seguinte roteiro para a realização das entrevistas:

- Nome, idade e ano de nascimento do entrevistado; 
- Como era constituída a família (quantos irmãos, posição na família; ocupação dos pais e demais familiares);

- Nome da escola onde estudou;

- Ano de ingresso na escola;

- Descrição da escola e da sala de aula;

- De quais materiais escolares dispunham;

- Como era a alimentação na escola;

- Como era o transporte de casa até a escola;

- Como foi o percurso escolar (repetência, até que ano/série estudou, quando saiu da escola e por que)

- Qual a contribuição do conhecimento adquirido na escola para a vida subsequente.

O procedimento a ser desenvolvido nesta pesquisa situa-se, ainda que não exclusivamente, dentro desse referencial metodológico. Será verificada também, à luz do conceito de ideologia, a articulação existente entre as questões que atravessam o processo de escolarização e de exclusão social.

Foi a partir desta ótica que se optou por perguntas abertas, o que possibilitou aos ex-estudantes o reavivamento de suas memórias e a construção de narrativas que se revelaram material fundamental para o desenvolvimento desta dissertação e para a construção de uma visão histórica do processo de escolarização dessas pessoas. Essa perspectiva rompe com o universo simbólico do sempre igual e homogêneo que tem cumprido o papel de apagar o sujeito em sua singularidade e ignorar a diversidade sociocultural.

\subsubsection{A estratégia de análise}

Foi feito um levantamento do número de escolas rurais existentes no município de Atibaia, desde as primeiras escolas surgidas no meio rural, por volta de 1945, passando pelas sucessivas reformas administrativas que culminaram recentemente com o fechamento de diversas unidades. Estes dados estatísticos constituirão um quadro mais geral em suas grandes linhas, por ser importante também neste trabalho denunciar o fechamento de escolas, porém o conteúdo significativo das questões será captado através da análise de dados qualitativos devidamente sistematizados. Tudo isto dentro de um quadro histórico dividido em 
períodos que correspondem grosso modo, as modificações na estrutura da sociedade rural, coincidindo (conforme pudemos verificar) com diferentes perspectivas na maneira de se encarar o sistema escolar em sua articulação, mais ou menos clara com os interesses políticos e econômicos hegemônicos no perído estudado.

O período de 1960-1985 foi marcado pelo nacional desenvolvimentismo, pelo avanço das classes populares e pelo extremo retrocesso político, social e educacional marcado pelo golpe civil militar de 1964. Buscou-se explicar as ocorrências educacionais, a partir da Lei 5692/71, as reformas dos militares e a repercussão no campo e consequentemente, na escola rural, evidenciando os processos de lutas e os movimentos de resistência que se desenharam, principalmente no final dos anos de 1970 e início dos anos 1980.

Para ilustrar os impactos destas transformações e evidenciar a importância da memória e a diversidade cultural existentes nas escolas rurais de Atibaia-SP, pretende-se sistematizar conhecimentos a partir da História Oral. Os depoimentos colhidos foram analisados evidenciando as mudanças e riquezas nas trajetórias dos sujeitos. Revelaram também o papel socializador da escola incluindo a resistência cultural dos sujeitos às múltiplas formas de dominação e alteração no seu modo de vida. Carlos Rodrigues Brandão, (2002), lembra a necessidade de compreender o que significa para as crianças do meio rural, o ato de estudar. a experiência cultural de estudar.

A análise dos depoimentos foi feita tendo como âncora os conceitos de trajetória e habitus, criados por Bourdieu (1975, 2003) e retomados por Trigo (1998) e Montagner (2007). Para esse autor toda trajetória social deve ser compreendida como uma maneira singular de percorrer o espaço social, onde se exprime as disposições do habitus, definido por ele como a aptidão que tem os agentes de se orientarem espontaneamente no espaço social e a reagir de modo mais ou menos adaptado aos acontecimentos e situações, lembrando que o agente ou grupo social ocupam sucessivamente uma série de posições, em um espaço submetido a transformações incessantes. (Montagner, 2007).

Trigo (1998), por sua vez explica que a vivência das mesmas condições objetivas organiza no indivíduo um sistema de disposições duráveis que tende a reproduzir as estruturas geradoras. Para a autora, o habitus é um sistema de estruturas estruturantes, ou seja, um princípio gerador de práticas e representações 
formado no indivíduo pela interiorização dos determinantes sociais. À medida que se repetem, as experiências pontuais e concretas acumulam-se e estruturam-se em disposições gerais. Assim, agentes de um mesmo segmento social, vivendo as mesmas condições de vida, tendem a incorporar as mesmas disposições que, ao se interiorizarem, transformam-se em verdadeiros traços de personalidade, ou seja, em uma segunda natureza, profunda e durável.

É esse conjunto de disposições, o habitus, que sistematiza todas as formas de agir, pensar e perceber dos agentes. Nesse sentido o habitus é um sistema de disposições abrangente que pode ser aplicado às práticas nos mais variados campos sociais, dando-Ihes unidade. Logo, para a compreensão do habitus de uma pessoa é preciso compreendê-la em sua família, na escola, com seus amigos e colegas e nos mais diferentes lugares por onde convive e sobretudo, as expectativas em relação à vida, em suma sua trajetória social. (TRIGO, 1998).

Para Trigo (1998), as posições ocupadas pelos agentes no interior dos campos, trazem implícito o sentido de trajetória. Para que se entendam os comportamentos dos agentes em um determinado campo, é preciso que se conheça a trajetória que percorreram até a ocupação de uma certa posição em um dado momento.

Assim, nesta pesquisa foi de fundamental importância buscar nas entrevistas realizadas, relatos que não se restringissem à trajetória educacional de cada entrevistado, mas também captar as projeções da complexidade vivida nas dimensões do simbólico.

Optou-se por delimitar alguns conceitos que contribuíram ao longo da pesquisa para a análise das narrativas e que é necessário esclarecer, como: cultura, violência simbólica, opressão e libertação, bem como trazer alguns aportes do debate teórico-conceitual da Educação do Campo e da Educação Rural.

A cultura para Bruno (2004) é compreendida em dupla dimensão: a cultura como acesso ao social, isto é, como produto e como produtora da vida em comum e como meio e consequência do viver junto, com desdobramento da sociabilidade e do ser político das sociedades humanas. É nesta dimensão que transcorre o processo no qual as sociedades definem como as diferenças haverão de ser vividas, praticadas e institucionalizadas. A autora aponta que a vida humana, e, portanto, 0 comportamento humano, transcorre na inter-relação entre três esferas distintas: a da natureza, a das instituições e a simbólica. A cultura é o elemento que expressa esta 
interação, em situações e tempos históricos dados. Para os fins desta pesquisa, adotaremos esta concepção de cultura por sua fecundidade na análise das narrativa aqui recolhidas.

$\mathrm{Na}$ sociedade de classes, a cultura tem um caráter multifacetado e fragmentário onde, apenas de forma tangencial, os excluídos participam dos benefícios da modernização. Soma-se a isso, a desvalorização dos conteúdos e práticas das suas subculturas, face à manipulação que sofre a própria cultura dita legítima, degradada em forma de indústria cultural e imposta como universalmente válida. Nesse processo ideológico, há que serem ressaltados os mecanismos de resistência daqueles que sofrem a dominação. (WHITAKER, 1984, p. 12).

Certeau (1998), ao analisar a vida cotidiana, defende que é um erro acreditar que o consumo das idéias, valores e produtos pelas pessoas é uma prática exclusivamente passiva, uniforme, limitada pelo conformismo, às imposições do mercado e dos poderes sociais, que estabelecem a estratégia de funcionamento da sociedade. Para esse autor, na prática, os "sujeitos anônimos" desenvolvem microresistências ou táticas articuladas nos detalhes do cotidiano, promovendo apropriações e ressignificações imprevisíveis, incontroláveis, modificadoras das pretensões previstas na origem, no planejamento, na idealização do funcionamento da sociedade. (CERTEAU, 1998).

Bourdieu e Passeron (1975) partem do princípio de que a cultura, ou o sistema simbólico, é arbitrária, uma vez que não se assenta numa realidade dada como natural. O sistema simbólico de uma cultura é uma construção social e sua manutenção é fundamental para a perpetuação de uma determinada sociedade. Os autores argumentam que a violência é simbólica precisamente porque é desconhecida como violência. Os agentes sociais se envolvem e aceitam um conjunto de pressupostos fundamentais sem reflexão, simplesmente porque acreditam que isso é natural. Assim, a cultura dominante consegue impor-se à cultura dominada de forma dissimulada. O dominado não se opõe ao seu opressor, já que não se percebe como vítima deste processo: ao contrário, o oprimido considera a situação natural e inevitável.

A violência simbólica pode ser exercida por diferentes instituições da sociedade: o Estado, a mídia, a escola, a família, etc. A Educação, no entanto, está no centro desta discussão. Ela poderia, pelo menos teoricamente, ser um agente transformador ao evidenciar as relações entre dominantes e dominados e prover 
uma reflexão crítica libertadora. No entanto, reproduz e legitima o poder simbólico (e real) da classe dominante. Nas palavras de Bourdieu:

Os intelectuais estão sem dúvida entre os mais mal situados para tomar consciência da violência simbólica (particularmente aquela exercida pelo sistema escolar) porque eles próprios por ela passaram com muito mais intensidade que a média das pessoas e porque continuam a contribuir para o seu exercício. (Bourdieu, 1975, p. 145);

Os educadores, ao não reconhecerem a violência simbólica, negligenciam as desigualdades sociais, econômicas e culturais de seus alunos. A escola e o ensino são vistos como homogêneos e, obrigatoriamente, como iguais para todos. Essa convicção nega a heterogeneidade do grupo ou a singularidade de cada ser, estabelecendo--se um padrão a ser seguido por todos (Hidalgo, 2014).

Há que se considerar que o processo de escolarização se dá no seio de conflitos de base ideológica, sendo necessário neste estudo ter por horizonte as formas de dominação e resistência da população às diferentes formas de violência engendradas, no caso da escola rural, pelo Estado enquanto representante do poder dominante.

Paulo Freire (1977) em a Pedagogia do Oprimido, defende que apenas o oprimido ou dominado é capaz de se libertar da opressão. Jamais essa libertação ocorrerá pelas mãos dos que exploram e violentam em razão de seu poder. Mesmo aqueles que se julgam "generosos" frente aos oprimidos têm necessidade da permanência da injustiça, pois essa falsa generosidade se alimenta da morte, do desalento e da miséria. Oprimidos, para Freire, são os esfarrapados do mundo, os condenados da terra, os demitidos da vida. Só com a libertação é que os oprimidos serão capazes de fazer a transformação necessária.

Há uma autoridade pedagógica que, na concepção de Freire, reproduz os modos de existência de opressão e exploração impregnados nos chamados conteúdos curriculares. A pedagogia do oprimido tem como objetivo levar o professor à reflexão crítica de sua práxis. Considera que tal práxis só é possível pelo diálogo, isto é, quando a ação e a reflexão sobre a ação são realizadas por todos os envolvidos e quando todos, em colaboração, buscam reconstruir o mundo e transformá-lo em um contexto de convivência solidária.

A pedagogia que liberta o oprimido é aquela que se baseia na prática humanizadora permeada por uma relação dialógica entre educador e educando, que 
se encontram numa tarefa em que ambos são sujeitos na transformação da realidade. Cabe a ambos desvendá-la, criticá-la e recriá-la.

O debate entre os conceitos de educação rural e educação do campo está ligado ao contexto do atual estágio em que se encontra a sociedade brasileira, em suas diversas faces: econômica; política e, sobretudo, no ressurgimento e fortalecimento dos movimentos sociais, principalmente 0 movimento social organizado no campo.

O conceito de educação do campo surge, conforme Arroyo et alii (2004, p.11) de um outro olhar sobre o campo e de diversas reflexões e indagações sobre a educação em geral no Brasil. Questões sobre a relação campo-cidade num projeto de desenvolvimento, calcado no direito à educação, na democratização e na participação da sociedade e o direito à inclusão social, apontam a urgência de uma nova compreensão da função social e cultural da escola.

Estas questões, entre outras de grande relevância, tais como a necessidade de definições sobre qual escola, qual pedagogia e qual currículo, animaram os debates da I Conferência Nacional "Por Uma Educação Básica no Campo", realizada em Goiás, no ano de 1998, promovida pela CNBB (Conferência Nacional dos Bispos do Brasil) - MST (Movimento dos Trabalhadores Rurais Sem Terra) UNICEF (Fundo das Nações Unidas para a Infância) - UNESCO (Organização das Nações Unidas para a Educação, Ciência e Cultura) e UnB (Universidade de Brasília). O documento final resultou na aprovação das Diretrizes Operacionais para a Educação do Campo - Parecer no. 36/2001, da Câmara de Educação Básica do Conselho Nacional de Educação.

Em 2002, foi realizado o Seminário Nacional "Por uma educação do Campo", em Brasília. O grupo que organizou o seminário - Articulação Nacional Por Uma Educação do Campo: Declaração de 2002 -propôs ações para o governo do Partido dos Trabalhadores, recém-eleito. Essa movimentação de educadores e militantes resultou em medidas que transformaram, pelo menos em parte, a estrutura da administração da educação no governo central.

O Ministério da Educação passou, a partir de 2007, a contar com uma secretaria para cuidar de assuntos específicos, relativos à diversidade como é o caso da educação do campo; foi criada a Secretaria de Educação Continuada, Alfabetização, Diversidade e Inclusão, composta por várias diretorias, entre elas a Diretoria de Políticas de Educação do Campo, Indígena e para as Relações Étnico- 
Raciais que por sua vez conta com uma Coordenação Geral de Políticas de Educação do Campo.

Essas medidas de ordem política possibilitaram a legitimação por parte do Estado da especificidade da educação das populações que não vivem nas cidades e a colocação do tema da educação do campo ou educação rural na agenda de debates e a formulação de políticas públicas para a educação do campo, que serão objeto de análise mais adiante.

Para Ribeiro (2013), a educação do campo propõe-se à superação da educação rural. Questões importantes são colocadas pela autora para situar a atual condição daquilo que se pensa da educação no campo atualmente, no tocante à política educacional em andamento.

Souza (2008) defende que há, no debate acadêmico, uma diferença primordial entre educação do campo e educação rural. Esta última estaria atrelada ao papel do Estado e suas preocupações com o atraso educacional que permeava o meio rural no início do século XX, no Brasil. Nessa concepção, o homem do campo era exemplo de atraso e a política educacional se organizava em conformidade com os interesses capitalistas. À parte algumas experiências, dentre elas as desenvolvidas por Paulo Freire, havia um predomínio de uma educação que objetivava educar os sujeitos rústicos do campo, "treinar e educar" os sujeitos "rústicos" do ambiente rural. A educação do campo, ao contrário, questiona esse paradigma da educação rural e propõe um novo paradigma que questiona, em essência, os interesses da classe dominante e as contradições do modo de produção capitalista. A autora conclui que:

A concepção de educação rural expressa a ideologia governamental do início do século $X X$ e a preocupação com o ensino técnico no meio rural, considerado como lugar de atraso. Já a educação do campo expressa a ideologia e força dos movimentos sociais do campo, na busca por uma educação pública que valorize a identidade e a cultura dos povos do campo, numa perspectiva de formação humana e de desenvolvimento local sustentável. (SOUZA, 2008)

Porém, Souza (2008) reconhece que a distinção conceitual não diminuiu a precariedade das escolas públicas. Muitas passaram por um processo de nucleação que levou ao fechamento de escolas e fortalecimento de escolas localizadas numa área central, entre bairros ou vilas rurais, prejudicando alunos que passaram a percorrer uma distância maior entre a moradia e a escola. A mesma precariedade 
ocorre na prática pedagógica, em que há poucos professores com formação superior para atuar no magistério, e na infraestrutura de bibliotecas e acesso a materiais didáticos.

O que fica do esforço em empreendermos esta conceituação, ainda que de forma provisória, é que a atual política educacional voltada para a população que não vive na cidade está atrelada, como no passado, ao modelo de desenvolvimento em curso, e que, independente da denominação ou conceito que venha a se estabelecer, os rumos da política educacional em questão dependerão da correlação de forças entre as classes sociais e a configuração do poder político no atual estágio do capitalismo. Um bonito trecho de Carlos Rodrigues Brandão nos conduz a uma reflexão sobre a escola rural:

(...) deixo como cenário a própria escola e convoco à cena o mundo rural de meninos e meninas, de pais e filhos, de pequenos trabalhadores rurais estudantes. ...as similitudes e diferenças entre eles, suas idéias sobre o "trabalho de saber" e o valor da educação que, segundo crêem, só a escola pode oferecer. (BRANDÃO, 1990, p.5).

Finalizamos o capítulo com mais uma fala poética de Brandão (1990), que nos lembra que todos os dias nascem crianças; todos os anos crianças são matriculadas nas escolas; caso haja; jovens procuram estudar em escolas, quaisquer que sejam elas, desde que Ihes sejam dadas condições mínimas de freqüentá-las e acompanhá-las. 


\section{Capítulo 2 - Quadro histórico social do Brasil: as transformações ocorridas} nos anos 1960, as reformas dos militares e a repercussão no campo e na escola rural. As lutas e movimentos de resistência.

O presente capítulo está divido em três partes e tem como objetivo contribuir para a compreensão do contexto social, econômico e político do Brasil, no período da Ditadura Militar, bem como verificar as implicações para a educação rural no que se refere à intensificação do processo de urbanização ocorrido a partir dos de 1930, com a configuração do Estado Nacional brasileiro chegando à década de 1980, focalizando as reformas educacionais e analisando-as a fim de fazer aproximações entre o que foi formulado pelo Estado e as ocorrências na realidade das escolas rurais.

\subsection{Antecedentes históricos do Golpe Militar de 1964: a formação da burguesia e do Estado Nacional Brasileira.}

A década de 1950 foi o segundo momento de irrupção do capitalismo monopolista no Brasil como realidade histórica. É nesse período que a economia brasileira passa a concorrer, não só para intensificar o crescimento do capitalismo monopolista no exterior, mas é incorporada a esse crescimento, tornando-se a partir daí um dos seus pólos dinâmicos na periferia (ACCIOLY e SILVA, 1995).

Para melhor compreender a complexidade desse período é necessária uma retrospectiva que permita acompanhar o processo histórico brasileiro, em suas linhas estruturais, no período compreendido entre as duas Guerras Mundiais, época crucial para a história contemporânea de nosso país, primeiro grande momento de incorporação do Brasil ao capital monopolista (ACCIOLY e SILVA,1995).

Segundo Florestan Fernandes (1975), as quatro décadas que se seguiram ao final da Primeira Guerra Mundial constituem o período central de maturação histórica da burguesia brasileira, já que para ele a formação dessa burguesia é muito anterior. Para Fernandes:

A burguesia surge a partir do rompimento do estatuto colonial, ligando-se à criação do Estado Nacional e às suas conseqüências sócioeconômicas sendo a grande lavoura a primeira esfera na qual ocorre "a reelaboração dos móveis capitalistas de ação econômica". (FERNANDES,1975, p. 27) 
O autor explica que embora a sociedade global e a organização interna da grande lavoura não se tenham alterado de modo imediato, as potencialidades capitalistas do latifúndio monocultor foram crescendo, especialmente nas regiões que conseguiram vigor econômico através do café, como foi o caso do Estado de São Paulo. Desse modo, parte significativa das potencialidades capitalistas da grande lavoura foram canalizadas para o crescimento econômico interno, o que permitiu a concentração de forças para a fundação de um Estado nacional, bem como a intensificação do desenvolvimento urbano e a expansão de novas formas de atividades econômicas, exigidas pelos dois processos. Ainda para o autor, este processo foi lento e convulso, de transição para a sociedade nacional e consolidação do capitalismo no Brasil. (FERNANDES, 1975).

O fato histórico marcante nesse período é:

o amplo e profundo processo de socialização do poder econômico, social e
político, pelo qual as classes sociais burguesas se unificam, a partir de sua
situação material de interesses, de seu estilo de vida e de sua concepção
de mundo. O predomínio dos interesses agrário-comerciais, de início, pôs
certos obstáculos a esse processo. No entanto, a Revolução de 30 indica
que ele já se havia aprofundado e difundido seriamente, muito antes que os
interesses industriais e financeiros lograssem a predominância relativa que
iriam alcançar com o Estado Novo e, especialmente, durante e após a
Segunda Guerra Mundial. (FERNANDES, 1975, p. 311)

Segundo Fernandes (1975), a integração do campo burguês, ou capitalista, em escala nacional, congregando-se numa comunidade política unificada, foi um processo difícil e complicado, não devido ao elemento oligárquico em si mesmo, mas porque era necessário arrancar o ethos burguês do cosmos patrimonialista em que ele fora inserido, graças a quase quatro séculos de tradição escravista e de um tosco capitalismo comercial.

Era necessário também, que as classes burguesas fizessem um esforço de revisão e redefinição de ideologias e utopias, assimiladas da experiência democrático-burguesa européia e norte-americana, da época da emancipação nacional em diante; e que conseguissem compreender qual é a própria realidade, em termos dos papéis e das tarefas históricas que poderiam desempenhar, como e enquanto burguesia de uma sociedade de classes subdesenvolvida e dependente na era do capitalismo monopolista e do imperialismo total. Para governar seu mundo, continua Fernandes, as classes capitalistas deviam iniciar por conhecê-lo melhor e por introduzir a racionalidade burguesa na compreensão de seus papéis históricos sob o capitalismo dependente (FERNANDES, 1975). 
Entender o desenvolvimento do capitalismo no Brasil, nas bases apontadas por Fernandes (1975), que nos indica a formação do Estado e da estrutura de classes que viria a se reproduzir durante o século $X X$, é fundamental para que possamos analisar em que medida esse processo determinou a influência da burguesia industrial brasileira que a partir de então passa a representar poder político do Brasil.

Neste sentido, concordando com Accioly e Silva (1995), o Estado que se configura pós 1930 é literalmente um Estado autocrático e oligárquico na medida em que se resguarda legalmente apresentando estruturas e funções democráticas que representam os interesses da classe dominante. Cabe ao Estado prover as condições necessárias para a acumulação do capital.

lanni (1986) por sua vez, nos explica que a Revolução de 30 criou as condições para o desenvolvimento do Estado burguês, entendido como um sistema que engloba instituições políticas e econômicas, bem como padrões e valores sociais e culturais do tipo propriamente burguês. Portanto, a Revolução de 30:

\begin{abstract}
representa uma ruptura política, econômica, social e cultural com o Estado oligárquico vigente nas décadas anteriores. Embora a cultura brasileira, ainda permanecesse impregnada das heranças dos valores e padrões da sociedade escravocrata, da predominância dos estilos de mando, liderança e organização do tipo oligárquico, os grupos políticos que chegaram ao poder, diante da inadequação das superestruturas político-administrativas então em vigor, passaram a modificar os órgãos governamentais e a inovar na esfera da política econômico-financeira.(IANNI,1986, p. 30).
\end{abstract}

Embora ainda estivesse ligado aos interesses dos cafeicultores, nos anos de 1930-45, o governo ditatorial de Getúlio Vargas teve condições de planejar e efetivar ações que provocaram a reformulação dos ideais e padrões do tipo capitalista. Nesse período, foram criadas estruturas administrativas para executar as medidas planejadas: o Ministério do Trabalho, Indústria e Comércio, Conselhos para todos os ramos da produção, e, no que tange à educação foi criado o Ministério da Educação e o Serviço Nacional de Aprendizagem Industrial (SENAI) (IANNI, 1986).

Essa organização do Estado brasileiro foi o suporte para o desenvolvimento econômico, social e político do Brasil, simbolizado na industrialização acelerada, que por sua vez, provocou uma sequência de rompimentos políticos e econômicos internos e externos, que ocorreram, grosso modo entre a Revolução de 1930 e o Golpe de Estado de 1964.Em suma pode-se dizer que as reformas efetivadas no Estado favoreceram o fortalecimento do capitalismo no Brasil, ancorado desde então 
na centralização estatal, exigindo de forma cíclica períodos de autoritarismo extremo.

\subsubsection{As realizações do Estado e da Sociedade no campo da educação: a organização do ensino (1930-1964).}

Devemos considerar o processo histórico da escola rural a partir de 1910/20, momento em que a sociedade brasileira "despertou para a educação rural por ocasião do forte movimento migratório interno, quando um grande número de trabalhadores rurais deixou o campo em busca das áreas onde se iniciava um processo de industrialização mais amplo" (LEITE, 2002, p. 28).

Contudo, segundo Feng e Ferrante (2007), não houve uma efetiva adequação da escola para a realidade rural, pois não se levou em consideração que a "educação é ampla, multifacetada, variável de conformidade com o 'espaço' humano racional em que é possível aflorar. Por isso existem tipos e formas educacionais diferentes, entre elas - a educação rural".

O debate sobre a educação rural ressurge em iniciativas concretas, diante também de um quadro de intensificação das migrações agravadas pela queda mundial dos produtos agrícolas, decorrente da crise de 1929, como é o caso do café. São exemplos destas iniciativas as missões rurais pelo interior, com uma postura assistencialista, atendendo as populações marginais às linhas férreas, além da realização do 1ํㅡㄹ Congresso Nacional de Ensino Regional, em 1935, quando se propuseram os cursos de formação para o magistério da zona rural. Como nos afirma Maia (1982):

O movimento ruralista que envolve políticos e educadores é muito mais do
que uma tomada de consciência sobre os problemas da educação rural. O
que realmente o define é sua face político-ideológica que permanece oculta
pela questão educacional. Comprometido com a manutenção do "status
quo", contribui para uma percepção enviesada da contradição cidade como
algo "natural", concorrendo consequentemente para sua perpetuação. Ao
que parece, a grande "missão" do professor rural seria a de demonstrar as
"excelências" da vida no campo, convencendo homem a permanecer
marginalizado dos benefícios da civilização urbana. (MAIA, 1982, p.28).

Maia (1982) destaca ainda a criação, em 1937, da Sociedade Brasileira de Educação Rural, que tinha por objetivos a expansão do ensino e a preservação da arte e folclore rurais. Esta iniciativa explicita o papel da educação enquanto 
instrumento de propagação ideológica: alfabetizar sem descuidar dos princípios de disciplina e civismo. Houve uma inegável ampliação da rede escolar no Brasil, mas em relação à área rural, os padrões de qualidade continuaram precários, com falta de qualificação dos professores, quase todos leigos, na precariedade das instalações escolares, na falta de materiais e equipamentos que resultaram nos altos índices de evasão e repetência. Somado ao caráter estrutural e ideológico da escola, destacamos a necessidade de as crianças abandonarem os estudos em decorrência da necessidade de sua mão de obra e complementação da renda familiar. Para a autora:

Esses fatores que dizem respeito às condições específicas de organização e funcionamento da escola rural não atuam isoladamente. Interagem com os determinantes econômico-sociais da estrutura agrária que não podem ser minimizados quando se apontam alternativas para o problema. (MAIA, 1982, p.28).

Esse quadro de precariedade da educação rural que se repete na zona urbana e demonstra a situação de precariedade da educação no Brasil pós-1930, período em que esteve fortemente vinculada ao desenvolvimento econômico. Conforme nos aponta Romanelli (1984:127), apesar do progresso alcançado, a educação distanciou-se muito em relação ao desenvolvimento. É fato que houve uma expansão quantitativa, no entanto insuficiente porque foi contida pela inelasticidade da oferta, pelo baixo rendimento do sistema escolar e por seu acentuado aspecto de discriminação social. Essas deficiências estruturais que vinham na contramão das necessidades produtivas aumentaram ainda mais a defasagem entre educação e desenvolvimento no Brasil. A manutenção e o aprofundamento dessa defasagem, a partir de então, vincular-se-ão às contradições políticas causadas pela luta entre os vários grupos das camadas dominantes na estrutura de poder. Essa vinculação se expressa pela organização do ensino que esses grupos conseguiram impor à sociedade, através da legislação educacional.

Nas décadas subseqüentes à Revolução de 1930, as características mais gerais no campo da educação, podem ser expressas por dois traços fundamentais, centralização e autoritarismo, que de forma contraditória conviveram com um dos mais fecundos momentos da elaboração do pensamento pedagógico brasileiro: As reformas Francisco Campos (1931-1932); o Manifesto dos Pioneiros da Educação Nova (1932) e as reformas Gustavo Capanema (1942-1946). (VIEIRA e FARIAS, 2003). 
Para Saviani (1997), essas medidas deixavam evidente a intenção da implantação de um Sistema Nacional de Educação. A própria Constituição de 1934 colocava a exigência de se fixarem diretrizes da educação nacional e a elaboração de um plano nacional de educação, evidências essas expressas pelas Leis Orgânicas do Ensino, configuradas nas reformas implementadas por Gustavo Capanema, então ministro da educação.

É importante aqui fazer uma breve incursão nos chamados "Tempos de Capanema", período em que a educação pública, tal como a conhecemos hoje, era precária, conforme Schwartzman et. al. (2000).

Ainda segundo Schwartzman et. al. (2000), a trajetória de Capanema, ministro por onze anos nos tempos autoritários do Estado Novo, se estende para os anos de abertura política pós-45. O ex-ministro participa da tentativa de dar continuidade à política educacional iniciada no primeiro governo Vargas: foi eleito deputado federal por Minas Gerais em todas as legislaturas a partir de 1946, pelo Partido Social Democrático e na ditadura militar pós-1964, foi eleito senador, pela Aliança Renovadora Nacional (ARENA), em 1971.

Desta forma, Capanema sempre esteve presente nos momentos importantes das disputas no campo da educação. Como ministro ou como parlamentar representou a corrente estatal, vencedora, na implementação de um sistema educacional centralizado e autoritário, voltado para a formação técnico-profissional. Este sistema, ao longo das décadas vem sendo legitimado e ao mesmo tempo corrompido pelo próprio Estado que o forjou, pois na prática, nunca chegou a desempenhar de forma plena o que seria sua tarefa mais desafiadora: a educação pública nacional para todos.

Assim, a aprovação de sucessivas leis e reformas não representou avanços significativos no campo da educação. Desde que esta se tornou um problema do Estado Nacional, quer autoritário ou democrático, a sociedade como um todo não logrou usufruir dos seus esperados benefícios, dado que avanços e retrocessos marcam o processo de instalação de um sistema nacional de educação.

No segundo governo Vargas, em que pesem os discursos e os propalados compromissos com a educação, tanto o ensino primário quanto o médio mostraram um frágil avanço. $O$ mérito que se pode atribuir ao governo nesse período, no que se refere à educação no Brasil, foi o de incrementar os gastos públicos globais com o ensino, já que este não sofreu nenhuma modificação significativa. Tal incremento 
concentrou-se especialmente nos ensino médio e superior, em detrimento do ensino primário. Trata-se, porém, de mérito relativo, pois os gastos federais com a educação caíram no governo getulista e a diminuição do processo de exclusão no ensino brasileiro foi mínima. (ACCIOLY e SILVA, 1995, p. 77).

O período que se abre após 1945, embora assinale a definitiva emergência do setor industrial como área mais dinâmica da economia brasileira, marca também a eclosão das contradições camufladas sobre o período anterior, em que a industrialização se beneficiará de conjunturas internas e externas favoráveis, como o aumento da renda gerado pelas exportações agrícolas e pela expansão das empresas privadas sobre a proteção do Estado, concentrada em poder de uma pequena parcela da população urbana. (XAVIER, 1990, p.41).

Aqui, destaca-se o processo de crescimento urbano-industrial em uma sociedade marcada pelo caráter agroexportador. Neste sentido, o campo começa a ser visto como local de atraso e os investimentos públicos concentram-se no meio urbano. No caso da educação, os avanços preconizados referem-se quase que exclusivamente ao ensino secundário e superior urbano, ficando o ensino primário, mais uma vez, em segundo plano.

O próprio Getúlio Vargas, em 1952, dizia que, em certos Estados brasileiros, cerca de $75 \%$ da população em idade escolar não tinha vagas para estudar. $\mathrm{Na}$ zona rural, onde em 1952 estavam perto de $60 \%$ das crianças brasileiras, só $38 \%$ delas estavam matriculadas no curso primário (ACCIOLY e SILVA, 1995).

O presidente dizia que este quadro provinha, em parte, da falta de prédios escolares adequados e de professores habilitados. Das 28.302 escolas primárias, apenas 4.297 eram públicas, devendo-se lembrar que somente $70 \%$ daquelas escolas haviam sido construídas para fins educativos. Vargas dispunha-se a buscar solução para os problemas do ensino primário, sobretudo na zona rural, por meio de convênios com os estados, visando a ampliação da rede escolar. (ACCIOLY E SILVA, 1995).

No breve governo de Café Filho (1954-1955), com a preocupação de fomentar a formação de mão de obra para a indústria, pretendia-se criar novas escolas, principalmente na zona rural e preparar melhor os professores. Quanto ao ensino médio, projetava-se fornecer uma educação integral à juventude, defendia-se a ampliação da rede escolar e prometia-se a assistência direta do governo federal às escolas, professores e alunos. $O$ ensino superior também era contemplado com 
promessas: o governo desejava consolidar as instituições universitárias já existentes e disciplinar os auxílios a elas. Do mesmo modo, não se descuidou de outras atividades educativas, como por exemplo a Campanha Nacional de Educação de Adultos, prevendo a instalação de 15.300 novos cursos em seu prosseguimento (ACCIOLY e SILVA, 1995).

No período seguinte, no governo Kubitschek, a estratégia de expansão assumiu caráter radicalmente diferente no que diz respeito ao padrão de acumulação, com a mesma correlação de forças do período anterior, o novo governo deu uma guinada radical alterando o padrão de acumulação e redefinindo o papel do Estado e as suas relações com a sociedade. Esses fatores provocaram a emergência precoce no Brasil do capitalismo monopolista de estado. (XAVIER, 1990).

Mais adiante, essa questão será aprofundada e verificar-se á como o capitalismo monopolista no Brasil se interligará com as reformas educacionais na década de 1970, e os efeitos da Lei 5.692/71 no ensino primário na zona rural, tema desta pesquisa.

$\mathrm{Na}$ administração de Juscelino Kubitschek, a política econômica sempre esteve acima da política social, o Programa de Metas, privilegiou quase unicamente alguns aspectos da economia brasileira, pois os 30 setores tidos como prioritários para os investimentos eram o setor de energia, transporte, alimentação e indústria de base. Na meta 30 do seu Programa ele deu ínfima relevância ao que chamou de social, quando aludiu à formação de pessoal técnico. Mais uma vez o entusiasmo ficou restrito às palavras, afinal o social integrava o universo ideológico, presidido pela noção de grandeza nacional e o desenvolvimento pautado no bem estar do povo. (VIEIRA, 2015,p.136).

O ideário juscelinista a respeito da educação pode ser observado em suas “Mensagens ao Congresso Nacional”. Em 1956, logo no início de seu governo, ele afirmava que iria "assistir todos os tipos de escolas necessárias à formação do homem". Indicando que sua administração teria duas orientações nesse sentido: a descentralização administrativa e a flexibilidade dos currículos. (ACCIOLY E SILVA, 1995).

Para além da preocupação pedagógica e administrativa, o objetivo central do governo permanecia refletindo os interesses da burguesia industrial e da elite agrária que mantinham forte influência junto ao Estado. Outro aspecto da política 
educacional de Juscelino era a insistência na necessidade de uma educação técnico-profissional, em todos os níveis de ensino. Apontava como muito útil a preparação de técnicos de nível médio que seriam destinados a trabalhar na indústria, no comércio, na agricultura e até no ensino primário. O governo, com essas medidas, procurava conter a enorme quantidade de candidatos às universidades, reservando para os estudos "propriamente intelectuais", aqueles que tivessem tal vocação e encaminhando para os cursos profissionalizantes os demais estudantes. (ACCIOLY e SILVA, 1995).

Na década de 1950 são criadas a Campanha Nacional de Educação Rural (CNER) e do Serviço Social Rural (SSR). Ambas desenvolvidas para um ensino técnico que se limitava a repetir as fórmulas tradicionais de dominação, uma vez que não usou em seu programa os verdadeiros mecanismos da problemática rural. Apesar de todas as tentativas aplicadas pela CNER para a fixação do homem no campo, o êxodo rural foi provocado por interesses subjacentes ao processo de modernização agrícola. As raízes do êxodo rural são profundas, e nos induzem a pensar que a educação rural deu suporte ou se prestou a ser uma roupagem institucional ao processo expropriador do homem do campo.

Data de 1957, um interessante estudo do INEP, chamado "Inquérito sobre Trabalho e Escolarização de Menores na Agricultura". Este estudo atingiu 140 municípios das regiões agrícolas mais produtivas do país, apontando que:

"o menor constitui parte integrante da força de trabalho da família e esta é uma das razões perturbadoras da sua freqüência escolar (...) o pauperismo das populações, má distribuição das escolas, desestímulo do professor face aos vencimentos exíguos, mobilidade das populações, em especial dos mais pobres, sem terras próprias, coincidência do ano agrícola com o ano letivo.". (MAIA, 1982, p.29).

A contradição da política educacional de Juscelino pode ser observada em seus discursos sobre as altas taxas de analfabetismo na população brasileira. Ao mesmo tempo em que propalava que este problema era a raiz do atraso no Brasil, os investimentos públicos existentes eram prioritariamente destinados à formação de mão de obra qualificada para as empresas. Outra contradição é a insistência na alteração da Lei de Diretrizes e Bases da Educação, que tramitava no Congresso Nacional, sem tocar em questões cruciais, como a produção de material didático e as condições de vida, de trabalho e de remuneração dos professores. Conforme (ACCIOLY e SILVA, 1995): 
Dois momentos marcaram a tramitação do projeto da Lei de Diretrizes e Bases da Educação: o primeiro representou o confronto entre a tendência centralizadora (inspirada na Carta Outorgada do Estado Novo) e a tendência federativa-descentralizadora (trazida na Constituição de 1946). O segundo momento começou com o substitutivo do deputado Carlos Lacerda, este, concentrava seus ataques ao que chamava de monopólio estatal da educação, defendia ardorosamente também o ensino privado, ao lado da Igreja Católica e outros grupos confessionais. Em defesa do seu substitutivo Lacerda apelava para "o direito primordial da família de promover a educação e acompanhá-la de perto, a liberdade de ensino, o perigo de um retorno de ditaduras do tipo Estado Novo". (ACCIOLY e SILVA, 1995, p. 85)

A oposição a Lacerda foi feita com a intensificação da Campanha em Defesa da Escola Pública. Fernando de Azevedo lança em julho de 1959 o "Manifesto dos Educadores - mais uma vez convocados", ressaltando o valor da educação e da escola públicas.

Outro forte oponente às proposições de Carlos Lacerda foi Florestan Fernandes, rebatendo em 1960 a posição do primeiro com base na liberdade de ensino e descentralização e denunciando o privilégio dado pelo substitutivo Lacerda às escolas privadas. Florestan defendia que era preciso primeiramente garantir a qualidade e eficácia da escola pública, pois somente ela teria condições de receber qualquer pessoa, oriunda de qualquer camada social, sem nenhum tipo de segregação econômica, ideológica, racial ou religiosa. (Vieira, 2015, p.152).

É necessário explicitar a confusão no financiamento e no emprego dos recursos destinados à educação no Brasil na era Kubitschek. Segundo Vieira,

além das verbas utilizadas pelo Ministério da Educação e Cultura, havia também uma infinidade de cursos mantidos pela União, espalhados em vários ministérios: Ministério da Guerra, Ministério da Marinha, Ministério da Aeronáutica, Ministério das Relações Exteriores, Ministério da Agricultura, Ministério do Trabalho e Previdência Social, Ministério da Justiça, Ministério da Saúde, Ministério da Fazenda, no Instituto Brasileiro de Geografia e Estatística (IBGE), no Departamento de Administração do Serviço Público (DASP), na Polícia Militar do Estado da Guanabara, na Superintendência do Plano de Valorização da Amazônia, na Comissão do Vale do São Francisco, na Fundação Getúlio Vargas e no Instituto Brasileiro de Administração Municipal. Portanto custeando múltiplas atividades educacionais fora do âmbito do Ministério da Educação e Cultura, o governo federal promovia também periodicamente cursos na Petrobrás, no Banco do Brasil, na Superintendência da Moeda e do Crédito (SUMOC), na Companhia Vale do Rio Doce, na Legião Brasileira de Assistência (LBA), no Serviço Nacional da Indústria (SENAI). Ante tão confessada prodigalidade, causou desconfiança a alegação oficial da falta de recursos para a educação. (VIEIRA , 2015, p. 147).

Fernando de Azevedo continuou a combater a LDB mesmo depois de sua aprovação pelo Congresso Nacional. Alertava que o projeto aprovado instalaria a 
desordem e o desperdício nas escolas particulares, alargando o caminho, já aberto, à mercantilização do ensino privado. Azevedo antevia, o esbanjamento do dinheiro público e em decorrência a ruína do ensino público. (ACCIOLY e SILVA, 1995, p.88).

No mesmo sentido, Florestan Fernandes, durante a Campanha em Defesa da Escola Pública, (que brotara, segundo ele, da indignação provocada pela LDB), acreditava que, ao esclarecer as prioridades da Campanha, a população brasileira seria convencida da importância de preservar a escola pública. Florestan considerava necessário garantir a "qualidade e eficácia do ensino", por meio da escola pública. "A Campanha em Defesa da Escola Pública pretendia livrar o governo dos "interesses particularistas na esfera da educação", e acima de tudo levar opinião pública a inquietar-se com as questões educacionais do país, "independentemente de seu saber e prestígio". (VIEIRA 2015, p.150).

Os resultados incipientes da política de Kubitschek podem ser verificados nos dados da educação ao final de seu governo, em 1960. A situação não se alterara muito, dos alunos matriculados no primeiro ano do curso primário, aproximadamente $23 \%$ chegavam ao quarto ano. O rigor da exclusão se acentuava nas demais etapas: dos ingressantes no primeiro ano em 1954, apenas 3,5\% alcançavam e concluíam o ensino médio. No quesito formação profissional dos docentes, o quadro era desalentador, $48 \%$ dos professores não tinham formação adequada. (ACCIOLY e SILVA, 1995, p.84).

O período dos governos de Jânio Quadros e Jango Goulart mostrou aumento nas despesas públicas com a educação. Jânio dizia-se favorável à LDB e considerava o analfabetismo o principal problema educacional a ser combatido em sua gestão. Do governo Jango ficaram as experiências célebres de educação popular: com a crescente mobilização das massas, foi possível a criação do Plano Nacional de Alfabetização, cujas experiências mais relevantes foram o Movimento de Educação de Base (MEB), os Centros Populares de Cultura da UNE (CPCs.) e o Movimento de Cultura Popular (MCP) (ACCIOLY e SILVA, 1995, p. 90-91)

Saviani (1997), ao analisar esta questão nos aponta os limites da primeira Lei de Diretrizes e Bases, a Lei 4024/61. Iniciada em 1947, logo após a promulgação da constituição Federal de 1946, a LDB seria em tese, o caminho para realizar o preceito constitucional que definia a educação como direito de todos e o ensino primário como obrigatório para todos e gratuito nas escolas públicas. 
No entanto, depois de tramitar por treze anos, a LDB que fora aprovada em 1961, não correspondia às expectativas da sociedade, pois fora fruto da conciliação entre os diferentes grupos instalados no poder e seus respectivos interesses, sendo predominante a disputa entre ensino privado e ensino público, saindo vitoriosos os interesses privatistas. Por outro lado, o texto da própria lei já apontava para a isenção de responsabilidade do cumprimento da obrigatoriedade do ensino público, tanto por parte da família, que poderia justificar pelo "comprovado estado de pobreza" ou da parte do Estado, que poderia alegar "a insuficiência de escolas". (SAVIANI, 1997, p.6).

Em suma, o panorama da educação brasileira nos governos de Jânio e Jango preservou a tradição originária dos governos anteriores. Sem transformar na essência a Educação no Brasil, e até mesmo mantendo determinadas deformações e numerosos enganos no domínio do ensino, à administração juscelinista restou o empenho em incrementar levemente os gastos federais com as atividades de educação e pesquisa. (VIEIRA, 2015, p. 145).

E conforme Xavier (1990):

A escola brasileira dos anos 30 aos anos 60 acomodou-se
progressivamente à ordem econômico-social capitalista finalmente
constituída. A ambigüidade das interpretações históricas quanto à
adequação da escola brasileira às exigências da sociedade deve-se acima
de tudo à confusão entre a sociedade idealizada e a sociedade real,
tomadas como referencia para a análise. (XAVIER, 1990, p.160).

Faz-se necessário observar os avanços do breve governo de João Goulart, com características mais democráticas, que permitiram projetos na área da educação, principalmente o projeto revolucionário de alfabetização proposto e desenvolvido sob a liderança de Paulo Freire. Este projeto foi abortado a partir de 1964, com a instalação da ditadura militar.

\subsubsection{O período pós 1964 e as reformas dos militares.}

As limitações dos governos populistas desde o $2^{\circ}$ Governo de Getúlio até João Goulart, não foram superadas pelo Estado autoritário que se instalou em 1964, com sua lei de reforma do ensino superior e a nova lei de estruturação do ensino fundamental e secundário: Lei 5.540/68 e Lei 5692/71, respectivamente. A Lei 
5692/71 é fundamental para compreensão dos impactos da política educacional nas escolas, e consequentemente, nas escolas rurais objeto desta pesquisa.

Durante a década de 1960 a demanda pela escolaridade aumentou de forma significativa, impulsionada pela industrialização e urbanização. A crise da educação brasileira atingiu seu ápice, agravada pela ação da política educacional adotada após 1964.

Em um primeiro momento, a política dos militares, foi na direção de atender as exigências quantitativas da demanda social da educação. No entanto, sua ação vai ser ineficiente com o aumento da crise econômica. O governo, para conter a crise e, segundo sua ideologia, adota então uma política de contenção, que provoca o agravamento da crise no sistema educacional. Este a partir daí, já não respondia às exigências do sistema econômico, nem às demandas da educação.

Neste mesmo período, surge o Programa de Extensão Rural no Brasil, que de forma romântica acena com a possibilidade de transformar o rurícola brasileiro em um farmer norte americano do pós-guerra. Baseado em características de um ensino informal, o trabalho extensionista se apresentou como diferenciado e até incompatível face ao molde centralizado curricular do ensino escolar vigente. (LEITE, 1999).

Sua base de ação era a empresa familiar e o importante era persuadir cada um dos componentes familiares a usarem os recursos técnicos de produção para conseguirem maior produtividade e consequente bem-estar social. Assim, de forma paralela ao sistema de ensino formal, a extensão passou a utilizar o espaço físico escolar e lançou um projeto que priorizava "o desenvolvimento para uma vivência comunitária" constituindo-se em novas orientações previamente preparadas, descartando assim a dinâmica pedagógica dos professores rurais, considerando toda a metodologia até então desenvolvida como ultrapassada e sem objetivo imediato.

O Programa de Extensão Rural foi criticado por Paulo Freire (1983). Exilado no Chile, escreveu o livro Extensão ou Comunicação em que explicita o caráter superficial e autoritário do programa imposto aos camponeses. O autor aponta que a capacitação técnica não pode ser focalizada numa perspectiva humanista e científica, a não ser dentro do contexto de uma realidade cultural total.As atitudes dos camponeses com relação a fenômenos como o plantio, a colheita, a erosão, o 
reflorestamento, têm a ver com suas atitudes frente à natureza; com as idéias expressas na sua religiosidade, seus valores, etc. Como estrutura, esta totalidade cultural não pode ser afetada em nenhuma das partes sem que haja um reflexo automático nas demais.

O autor assinala que a capacitação técnica não pode acontecer sem que o agrônomo educador conheça a visão de mundo do camponês e sem confrontá-la em sua totalidade, assim o agrônomo-educador não pode efetuar mudança de atitudes dos camponeses em relação a qualquer aspecto sem conhecer o campo cultural onde atuará.

Paulo Freire (1983), nos mostra como o conceito de "extensão" engloba ações que transformam o camponês em "coisa", objeto de planos de desenvolvimento que o negam como ser da trans-formação do mundo. O mesmo conceito substitui a educação do camponês pela propaganda que vem de um mundo cultural alheio, não lhe permitindo ser mais que isso e pretendendo fazer dele um depósito que receba mecanicamente aquilo que o homem "superior" (o técnico) acha que o camponês deve aceitar para ser"moderno", da mesma forma que o homem "superior" é moderno.

Tonini (1975) ao pesquisar o impacto do programa de extensão rural no Rio Grande do Sul, concluiu que os grupos estudados não apresentaram diferenças estatisticamente significativas no conhecimento de práticas agropecuárias por influência do Programa de Extensão Rural. Tinha razão Paulo Freire.

Conforme Cunha e Góes (1985), os resultados do Censo Demográfico de 1970, no governo do General Médici, foram mais eloquentes que a fala do general presidente: "a economia vai bem, mas o povo vai mal". Por certo, não era a economia dos pequenos empresários, afogados pela competição das grandes empresas monopolistas e pelos juros escorchantes.

Os economistas do governo buscaram então, explicações fora do campo econômico, e, mais uma vez a educação foi apontada como causa da má distribuição de renda e responsável pela pobreza e desigualdade social no país. Para os defensores da política econômica da ditadura (da submissão ao imperialismo ao arrocho salarial), as diferenças de escolaridade é que determinavam as diferenças de rendimentos entre as pessoas. A ditadura usou e abusou dos meios de comunicação de massas para incutir na população essa crença no papel 
milagroso da educação. Para o governo e seus burocratas, a distribuição de renda mais igualitária viria, de forma automática como resultado de ampla distribuição de oportunidades educacionais para todos.

Exemplo dessa política educacional distributivista foi o Movimento Brasileiro de Alfabetização (MOBRAL), que se propunha a reduzir o analfabetismo da população em 10\%; o Projeto Minerva que era uma rede de ensino supletivo, via rádio e a televisão com novelas educativas. Recursos financeiros não faltaram para essas iniciativas, a Loteria Esportiva e os incentivos fiscais foram boas fontes de receita. No entanto, o fracasso dessa política foi estrondoso.

A política educacional da ditadura teve, novamente, como proposta central o ensino profissionalizante, representando um retrocesso em relação ao período anterior, especialmente no que se refere à articulação e resistência de diversos setores da sociedade, como estudantes, professores e intelectuais.

Os militares trataram de multiplicar os ginásios orientados para o trabalho (GOT) e tornar o $2^{\circ}$. Ciclo do ensino de $2^{\circ}$. Grau compulsoriamente profissional. Foram construídos cerca de 600 ginásios, espalhados pelo Brasil, o currículo foi alterado e disciplinas como Artes Industriais ou técnicas agrícolas (dependendo da região) eram oferecidas nas quintas e sextas séries. Nas duas últimas séries, aumentava-se a carga horária destinada às disciplinas vocacionais, os alunos poderiam optar por artes industriais, técnicas agrícolas, técnicas comerciais, educação para o lar ou aprofundamento de estudos gerais. Essas disciplinas vocacionais teriam o objetivo de continuar a sondagem vocacional, de modo mais profundo, de forma a facilitar a escolha de cursos profissionalizantes ou gerais, no então chamado $2^{\circ}$. Grau, aqueles que não prosseguissem os estudos já teriam uma iniciação profissional, facilitando o treinamento numa ocupação específica, já em serviço. (CUNHA e GÓES, 1985).

Na prática, o que ocorreu foi um desastre que poderia ser previsto, não fosse o autoritarismo dos militares e do Conselho Federal de Educação, conforme afirmam Cunha e Góis (1985). Acabaram-se os cursos clássico e científico, as célebres escolas técnicas e as escolas normais, famosas por formarem excelentes professores para atuarem no ensino primário.

Contrariando as pessoas que conheciam a fundo o mundo da produção, o governo encaminhou ao Congresso um projeto de lei (que veio a resultar na Lei 
5692/71). Sancionada a lei pelo general-presidente Médici, com a assinatura de seu ministro da educação, o coronel Jarbas Passarinho, passou-se à sua implantação.

As reformas introduzidas após a promulgação da Lei 5692/71 tinham como objetivo, entre outros, conter a demanda por ensino superior, através da formação de quadros técnicos de nível médio, trazendo assim muitas inovações em relação à organização prevista pela LDB de 1961.

Pela nova Lei 5692/71, os cursos primário e ginasial foram substituídos pelo ensino de $1^{\circ}$ Grau, destinado à formação da criança e do adolescente, com oito anos de duração e obrigatório dos sete aos catorze anos. O ensino médio passa a chamar-se ensino de $2^{\circ}$ Grau, destinando-se à formação integral do jovem, com três ou quatro anos de duração. Essas medidas podem ser sintetizadas em dois princípios: continuidade e terminalidade. A continuidade, manifesta-se no ensino de 1․ Grau de oito anos que na prática eliminou o exame de admissão, bem como na composição e estruturação do currículo composto por um núcleo comum obrigatório, a ser cumprido em âmbito nacional e a continuidade e terminalidade no $2^{\circ}$. Grau que previa também a formação profissional do jovem (ROMANELLI, 1984).

Se analisada dentro da especificidade do capitalismo na década de 1970 no Brasil, pode-se perceber que a Lei 5692/71 não trouxe de fato, novidades transformadoras. A partir de seus objetivos, gerais e de caráter conservador liberal, a lei em questão, acentuou as divergências sócio-políticas existentes na escolarização dos brasileiros e consagrou o elitismo que sempre esteve presente no processo escolar nacional, e prestou-se ainda ao cumprimento dos acordos feitos entre o Ministério da Educação e a Agency for International Development (AID) para assistência técnica e cooperação financeira, os chamados Acordos MEC-USAID, que entre outros, tinha como objetivo a eficiência e eficácia educacional, a ampliação curricular da escola brasileira, com vistas ao desenvolvimento do sistema produtivo, do qual a formação profissional da juventude fazia parte (LEITE, 1999).

A profissionalização universal e compulsória, no dizer de Cunha e Góes, (1985), foi duramente criticada em todos os setores. Além do desmantelamento do ensino médio e profissionalizante, os altos custos dos cursos, afastaram os empresários do ensino, os estudantes a encaravam como perda de tempo - nem profissionalizava, nem os preparava para o vestibular. Este fator levou ao aumento no número de "cursinhos preparatórios" e a expansão das escolas privadas de $2^{\circ}$ Grau. Do ponto de vista dos administradores da educação, a implantação do projeto 
que previa a profissionalização era praticamente impossível, mesmo se houvessem recursos suficientes faltavam professores e estrutura nas escolas.

Vale dizer que nessa época, para suprir a falta de professores especialistas para dar conta da grande variedade de disciplinas técnicas, que visavam a profissionalização do jovem e sobretudo a terminalidade do $2^{\circ}$.Grau, foram recrutados inúmeros profissionais de todas as áreas. Assim, advogados, contadores, engenheiros, médicos, dentistas entre outros, foram autorizados a dar aulas nas escolas públicas e privadas, formando um contingente de professores, sem a formação adequada, contratados em caráter temporário e precário. Essa situação teve impacto no ensino superior, acelerando o crescimento exponencial das faculdades privadas noturnas e de fins de semana, com a criação das licenciaturas curtas que visavam dar uma formação rápida para todos que pretendessem ingressar no magistério.

No que se refere ao currículo, tanto em nível de 1․․ Grau como também de 2ํ․ Grau, as disciplinas de Educação Moral e Cívica, Organização Social e Política Brasileira tornaram-se obrigatórias, História e Geografia foram substituídas por Estudos Sociais, e Artes por Educação Artística deixando evidente o controle ideológico da juventude, a quem fora subtraído o acesso ao conhecimento e à crítica. Todo o currículo escolar passou a ser controlado com a edição dos Guias Curriculares (Verdão), essa imposição de programas levou à expansão do mercado de livros didáticos descartáveis, cuja adoção era praticamente obrigatória em todas as escolas de nível básico.

Isso se configurou não apenas como controle curricular mas também como desestruturação da educação básica e superior. Em 1969, a publicação do Decreto 547, foi mais um ataque vigoroso na formação dos professores. Este decreto autorizou a implantação nas faculdades particulares de cursos de formação intermediárias, com duração de um ano e meio, para quem tivesse qualquer formação superior e no máximo de três anos para aqueles que tivessem concluído o

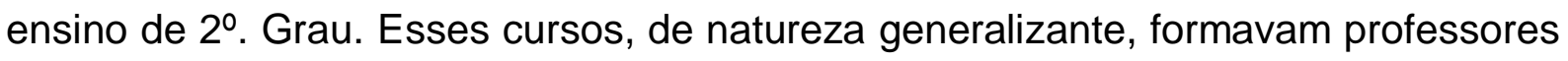
polivalentes de ciências humanas.

As críticas e resistências ao projeto dos militares ganharam força quando o "milagre econômico" arrefeceu, em 1973. Previa-se uma política econômica que dividiria profundamente as classes dominantes, bem como a própria base militar da ditadura. O governo não teve outra saída a não ser a "distensão". Essa situação 
teve reflexos na educação, o então ministro da educação Ney Braga deu a ordem para que o Conselho Nacional de Educação "reinterpretasse" a Lei 5.692/71. Nessa nova forma, o ensino profissionalizante de $2^{\circ}$. Grau passava a visar, para a maior parte dos alunos a educação geral.

As resistências continuaram com a pressão do movimento dos professores, dos empresários do ensino, dos estudantes e dos técnicos em educação. Em decorrência o Ministério da Educação, em associação com algumas universidades, promoveu estudos para modificação da Lei 5.692/71. Já não havia clima político para alteração de leis por um mero parecer do Conselho Federal de Educação. Encaminhado para o Congresso, foi aprovada a "reforma da reforma", a Lei 7.044/82 (CUNHA e GÓES, 1985).

Fracassada a política de profissionalização universal e compulsória, nada foi posto no lugar. O ensino público de $2^{\circ}$ Grau foi desorganizado e sua qualidade foi deteriorada. A função de conter o acesso ao ensino superior, que a ditadura esperava, não se concretizou e aumentaram-se as barreiras dos exames vestibulares, conforme estudado por Whitaker (1981).

Assim, um dos fatores de que depende o sucesso na atuação do Estado na implementação de suas Leis é a organização da produção e suas decorrências na vida social. Tinha razão Otaíza Romanelli ao afirmar, em seu indispensável trabalho publicado em 1978, ainda durante a ditadura:

\begin{abstract}
nenhuma lei é capaz, por si só, de provocar mudanças profundas e nem tampouco de retardar, também por si só, o ritmo do progresso de uma dada sociedade, por mais retrógrada que seja, porque sua aplicação depende de uma série de fatores. Em primeiro lugar, a eficácia de uma lei está subordinada à sua situação no corpo geral das reformas levados a efeito, paralelamente a outros setores da vida social, e, o que é mais importante, sua eficácia decorre de sua integração e de suas relações com todo esse corpo. (ROMANELLI, 1984, p. 179)
\end{abstract}

\title{
2.3. A educação rural no contexto das reformas pós-1964 no estado de São Paulo.
}

Diante do quadro apresentado no item anterior acerca das reformas na legislação, nos atentaremos neste momento à realidade das escolas rurais durante a ditadura militar, especialmente no estado de São Paulo.

Para Leite (2002), durante os anos de governo militar, a educação no campo enfrenta diversos problemas, dentre os quais se destacam o elevado índice de 
analfabetismo, sobretudo nas faixas etárias acima de 25 anos; a baixa remuneração e qualificação dos professores, com predominância de leigos responsáveis por classes, na sua maioria, multisseriadas; o elevado índice de exclusão e repetência; o crescente processo de municipalização da rede de ensino fundamental, que responde pela quase totalidade das matrículas nas séries iniciais das escolas rurais, sem que sejam viabilizadas as condições estruturais e pedagógicas.

O modelo de educação rural que esteve ligado aos projetos de modernização do campo brasileiro, levou a escola rural a uma imitação do processo urbano, constituiu um processo de descaracterização da sociedade camponesa, que mostra um formato escolar no qual há total desinteresse do Estado em promover uma política educacional adequada ao universo do campo.

Whitaker (1992) mostra que vinculado a este desinteresse do Estado existe uma ideologia predominante que alega que a falta de educação rural é causada pela não valorização da população rural, que coloca seus filhos precocemente no mundo do trabalho ao invés de pô-los na escola. Essa ideologia confunde as consequências com as causas dos fenômenos sociais e projeta na vítima a culpa pelos seus infortúnios.

No Brasil, o pós II Guerra Mundial despontou em uma crescente industrialização que se alastrou até o campo e acelerou a urbanização do país, neste processo ocorreu a migração da população rural para a zona urbana e do fluxo populacional do nordeste para o sudeste. Às desigualdades regionais somavam-se a anulação dos direitos civis e da cidadania, com a população sofrendo as ações repressoras do regime Militar.

O que se tem no Brasil de hoje, é um sistema caracterizado por elevado coeficiente de diferenciação e especialização funcional, circunstância facilmente observável, quando se atenta para a existência de cidades de porte considerável, e ao mesmo tempo destituídas de qualquer base industrial. Esta constatação tem implicações no campo da educação, conforme se verá. E se a dinâmica do processo urbano é gerada por impulsos oriundos da industrialização, é válido que se concentre a analise das relações entre urbanização acelerada e problemas educacionais, no Estado mais urbanizado e mais industrializado do país. (WHITAKER, 1979-p.46). 
Um dos mais notáveis fenômenos relacionados com a urbanização acelerada da América Latina é o crescimento da demanda por educação. Entre outros motivos isto ocorre porque na cidade, a educação escolarizada é agente de estratificação ocupacional, mais do que no campo. Importante perceber que a associação entre ocupação e escolaridade parece mais intensa nos países do 3o. Mundo do que naqueles que se desenvolveram antes (WHITAKER, 1979).

Segundo a autora, da demanda por educação, resultam duas consequencias : a primeira refere-se aos grupos que têm maior expressão política, que manipulam o atendimento escolar e este tem um crescimento que tende a atender às demandas por níveis mais altos de escolarização do que abarcar a totalidade da população nos níveis primários da escolaridade. A segunda consequência diz respeito às populacões urbanas as quais desenvolvem estratégias que forçam a reformulação das políticas educacionais. (WHITAKER, p.53, 1979).

Nesse contexto foi conferida aos Estados a responsabilidade de manutenção, organização e funcionamento do ensino primário e médio, bem como a garantia da obrigatoriedade escolar para crianças com idade de sete anos. Assim, foi deixado a cargo das municipalidades a estruturação da escola fundamental na zona rural. Contudo, as prefeituras municipais do interior são desprovidas de recursos humanos e financeiros, deixando as escolas rurais sem condições de continuidade funcional, culminando em um processo de deterioração da escola rural e submissão aos interesses urbanos.

Na década de 1970, em plena Ditadura Militar, a descentralização do ensino foi sempre apresentada como portadora de um conjunto de vantagens, nem sempre totalmente verdadeiras. Ela seria propiciadora de uma ação de política educacional menos burocratizada, permitiria maior flexibilidade nas mudanças curriculares e possibilitaria uma gestão mais democrática das escolas. Neste sentido a maior proximidade da população em relação ao poder público municipal pode fomentar oportunidades de uma gestão mais democrática, mas também de uma gestão subordinada às oligarquias locais.

Na Lei 5692/71 foi definida a vinculação à educação dos recursos do Fundo de Participação dos municípios, além de ter sido aplicado um reforço às estruturas técnicas e administrativas municipais para atuar na educação. No entanto, no estado de São Paulo o processo de descentralização ocorreu de forma gradual, sendo que 
no período da Ditadura Militar, não houve a municipalização com a mesma intensidade que nos outros estados da federação, principalmente o nordeste. No caso paulista, tal descentralização acentuou-se na década de 1990, no contexto do neoliberalismo globalizado dos governos Mário Covas e subseqüentes.

Feng e Ferrante (2006), citando Machado (2000) afirma que só na década de 1980, a escola pública rural vai passar por um processo de reforma, no Estado de São Paulo. Esta reforma, constituiu-se no agrupamento de escolas isoladas da zona rural em unidades maiores, eliminando-se as classes multisseriadas e obrigando os municípios a fornecerem transporte para as crianças das escolas que haviam sido fechadas.

Segundo Maia (1986), as escolas rurais encarregadas do ensino primário são praticamente mantidas apenas pelos poderes públicos, através das redes estaduais e municipais de ensino. Na década de 1970, com a extensão da escolaridade básica obrigatória de quatro para oito séries (Lei 5692/71), observou-se tendência das redes estaduais a concentrarem-se no ensino público urbano, tendo crescido a participação do ensino municipal nas áreas rurais. Ainda segundo a autora, na década de 1980 no estado de São Paulo:

Nas áreas rurais, diferentemente do conjunto do país, a administração estadual não só é a principal, como quase exclusiva mantenedora de escolas de primeiro grau no estado. (...). Em 1983, o estado mantinha 11.657 escolas rurais que correspondiam a mais de $95 \%$ da oferta de ensino na área rural. Estes estabelecimentos abrigavam um total de 281.447 alunos, representando em torno de $10 \%$ das matrículas da rede estadual de ensino. (MAIA, 1986, p.12).

Romanelli (1984), ao discorrer sobre a história da educação brasileira aponta a impossibilidade da aplicação das reformas no ensino, sobretudo aquelas propostas pela Lei $5.692 / 71$, face ao isolamento quase total das famílias e das escolas do campo.

Leite (1999) sobre a educação rural ao abordar a questão da lei 5.692/71 afirma que:

teoricamente a legislação abriu espaço para se repensar a educação rural, ao enfatizar que o ensino deve ater-se às peculiaridades regionais e locais, porém essa abertura ficou restrita ao próprio meio e sem contar com recursos materiais e humanos satisfatórios. Isso porque a lei, elaborada fora da realidade sócio-cultural do campesinato brasileiro, não incorporou as exigência do processo escolar rural em suas orientações fundamentais, nem mesmo cogitou possíveis direcionamentos para uma política 
educacional destinada, exclusivamente, aos grupos campesinos. (LEITE, 1999, p.48)

Ao final da década de 1970, no contexto da abertura política e refletindo os movimentos pela melhoria da escola pública e a pressão vinda do campo, novamente o governo passa a dar atenção à educação rural, que se torna mais uma vez prioritária, no dizer de Maia (1999). O Ministério da Educação elabora o documento intitulado "Educação para o meio rural - ensino de 1‥Grau - Política e Diretrizes de Ação (1975-1979), e segundo o documento citado por Maia (1999):

O governo está voltado para a promoção de profundas transformações no meio rural brasileiro, tendo como objetivo último e fundamental o bem-estar do homem rural brasileiro, mediante a ampliação das oportunidades de renda do trabalhador, a extensão dos benefícios da previdência social." O Plano Setorial de Educação e Cultura (1975-1979), com base nessas afirmações, então propunha-se a expandir a escolarização na zona rural pelo menos nas quatro séries fundamentais e melhorar o nível de ensino reduzindo a evasão e a repetência (BRASIL apud MAIA, 1999, p.29).

Cumpre dizer, no entanto, que a Lei 5.692/71 determinava a obrigatoriedade do ensino de 1 - Grau de oito anos o que coloca a questão: no meio rural a escolarização obrigatória retrocederia novamente aos quatro anos previstos na LDB de 1961 ?

É oportuno dizer que novamente o Estado impunha suas metas, desrespeitando a legislação e se desresponsabilizando pela situação precária da educação do campo. Conforme o documento citado por Maia (1999) indica e propõe:

(...) embora se tenha a consciência de que a chuva e a colheita solicitam mão-de-obra das crianças, estabelecemos o mesmo calendário escolar tanto para a zona urbana quanto para a zona rural;os professores que amiúde têm apenas uma formação urbana — quando a têm — ou seguem padrões urbanos; os materiais de ensino-aprendizagem são escassos devido não apenas à falta de recursos financeiros como também à dificuldade de acesso aos locais onde poderiam ser adquiridos.

Para superar tais dificuldades, recomenda-se que: a escola não pode negar o mundo rural, onde o trabalho constitui um valor, e o trabalho infantil, além de ser uma necessidade, é um valor social; o ensino ministrado na zona rural tem que ser apropriado a essa realidade; a escola da zona rural deve ser uma agência de mudança. (MAIA, 1999, p.29)

O documento, em que pese a importância dada à situação da educação rural, coloca os problemas conhecidos não só pelo poder público, mas também pela população usuária das escolas. Fica em aberto outra questão: a quem caberia a responsabilidade para resolvê-los? Podemos chegar a uma conclusão, ainda que 
provisória, de que formular leis e elaborar planos, sem tocar em questões estruturais, como o trabalho infantil, acesso ao trabalho e renda, formação de professores, acesso a materiais, entre outras questões de cunho político e econômico, não é suficiente para romper com a ideologia de que o mundo rural é um lugar atrasado, cada vez mais despovoado e que suas escolas não necessitam de investimentos para a superação da situação crônica de abandono.

Importante ressaltar que a partir da década de 1980 também é visível uma série de transformações no panorama da educação rural e na luta pela reforma agrária. Marcada fortemente por lutas e movimentos sociais como a do MST (Movimento dos Trabalhadores Rurais Sem Terra) e mobilizações em torno do processo Constituinte de 1988. Nos movimentos sociais existe a preocupação com um ensino rural que se adapte às características do meio rural. Os movimentos políticos no campo educacional brasileiro, como a Articulação Nacional por uma Educação do Campo, as reivindicações do movimento sindical dos trabalhadores rurais e o envolvimento dos mais diversos setores, deram força e vigor às idéias que garantiram a aprovação pela Câmara de Educação Básica daquele colegiado, somente em 2002, das Diretrizes Operacionais para a Educação Básica nas Escolas do Campo (Resolução CNE/CER n.t 1, de 3 de abril de 2002), uma reivindicação histórica dos povos do campo, significando um primeiro passo no sentido de resgatar uma dívida com este setor. 


\section{Capítulo 3. História oficial de Atibaia e a memória social: 0 que os depoimentos nos contam.}

Atibaia é um município do estado de São Paulo que apresenta algumas peculiaridades. Localiza-se a aproximadamente $60 \mathrm{~km}$ de duas grandes metrópoles - São Paulo, a capital do estado e Campinas, em cuja região administrativa Atibaia se insere.

A cidade é privilegiada pelo clima de montanha, tem status de Estância Climática e em decorrência desse fator, é proibida no município a instalação de indústrias poluentes, o que propicia ainda nos dias de hoje intensa atividade econômica rural, baseada no cultivo de flores e produtos hortifrutigranjeiros que se realiza em pequenas propriedades.

A cidade é antiga, foi fundada por bandeirantes do século XVII, pois era passagem obrigatória para a rota das minas de ouro em Minas Gerais. Desenvolveuse predominantemente em atividades agrícolas, sendo que somente no final do século XIX e início do século XX iniciou-se o processo de urbanização. (CONTI, 2001, p.16).

O antigo povoado, cuja fundação teria se dado no ano de 1653, foi resultado da doação de terras pelo antigo sistema de sesmarias, a primeira doação data de 1638. Note-se que a posse jurídica da terra não significou a ocupação efetiva. A sociedade que se formou vivia modestamente, se dedicando à agricultura e criação de animais para consumo, não se enquadrando nos interesses mais absorventes do comércio exportador do Brasil Colônia. Esta povoação demorou um século para tornar-se vila, pois somente em 1770 foi criada a Primeira Câmara.

uma história do cotidiano sem brilho e sem glórias, História que se registra porque é acontecimento, mas não empolga e não tem senão pequena repercussão no conjunto da história geral do país (Leite, 1966, p.1).

A região acompanhava a pobreza que caracterizou a Capitania de São Paulo no Século XVII e primórdios do Século XVIII. Neste século, intensifica-se a posse jurídica da terra ao mesmo tempo em que acontecia a posse efetiva. A região 
localizada nas vias de acesso à região das minas, passa a ser produtora de gêneros também para o comércio, abastecendo a sede da capitania.

Importante observar que os donos das terras poucas vezes cultivavam o solo ou nele colocavam escravos ou colonos para cuidarem da agricultura. A terra tinha pouco valor e faltava mão-de-obra. Por exemplo, o dono de uma fortuna estimada em 4.068\$360 (quatro contos, sessenta e oito mil, trezentos e sessenta réis), considerado homem rico nessa época, possuía sete escravos no valor de $290 \$ 000$ (duzentos e noventa mil réis), comparado ao preço de utensílios, roupas e ferramentas a terra pouco valia. (LEITE, 1966, p.11).

Muita terra e poucos homens, estes valiam muito porque a posse da terra dependia do seu trabalho. O negro escravo era caríssimo para os padrões da região. Assim em 1655 chegaram os índios Guarulhos, liderados pelo Padre Mateus Nunes Siqueira, provenientes da Aldeia Nossa Senhora da Conceição de Guarulhos. Esses indígenas, livres juridicamente, obedeciam a um regime servil, com a plantação de cana de açúcar, a instalação de alambiques, cultivo do milho, feijão, mandioca e outros tubérculos, marcaram a posse efetiva da terra.

Em 1680, foi erguida a 1‥Capela, em homenagem a São João Batista, por Jerônimo de Camargo, que por tradição é considerado o fundador de Atibaia. Este pertencia ao clã Camargo, de procedência espanhola, estava envolvido nos conflitos resultantes da retomada de Portugal, em 1640 do domínio espanhol. Assim Jerônimo de Camargo chega à região, abandonando a Câmara Paulistana e a Vila de São Paulo. (LEITE, 1966).

O texto acima sobre a história de Atibaia, resultou da consulta feita à dissertação de mestrado de Beatriz W. Cerqueira Leite, defendida em 1969 no Departamento de História da FFLCH da Universidade de São Paulo. A história de Atibaia foi narrada também pelo historiador atibaiano João Batista Conti, em três volumes, organizados pela Divisão de Memória Municipal da Secretaria de Educação e Cultura.

A obra de Conti (2001) foi resultado do estudo acurado de fontes documentais, que tratam da história da Vila de São Paulo, mais tarde Província de São Paulo e na observação curiosa dos acontecimentos políticos do Brasil de seus 
reflexos na sociedade atibaiana. Este autor dedicou-se à preservação da memória de Atibaia colecionando peças e documentos importantes que permitiram a fundação do Museu Municipal de Atibaia que leva seu nome. Historiador e cronista, narra a história de Atibaia, articulando-a aos acontecimentos marcantes da história de São Paulo e do país, com destaque aos "grandes vultos" da história de Atibaia, mas também narrando os aspectos culturais da sociedade caipira que aqui se formou.

Esta obra é composta por três volumes, dois dedicados à chamada história oficial, escrita conforme a tradição historiográfica do Séc. XIX. Com evidente ufanismo, conta as belezas naturais de Atibaia e de seu povo, com base em documentos escritos, tais como atas das sessões da Câmara Municipal, certidões dos cartórios, documentos eclesiásticos da Igreja Católica, jornais locais, poemas e crônicas deixados por frequentadores da cidade turística, entre eles os conhecidos, Guilherme de Almeida, Mário de Andrade, Martins Fontes e Menotti Del Picchia.

O terceiro volume, intitulado Atibaia Folclórica publicado em 2001 pela Secretaria de Educação e Cultura é a compilação de três volumes originais, datilografados, datados de 1950 e que fazem parte do acervo do Museu Municipal. Este excerto do texto de João Batista Conti, resume o teor da sua obra:

Esta é a história de uma cidade que, nascida no período das bandeiras, teve seu passado de luta dentro dos destinos da pátria, aparecendo nos grandes fatos da nossa história, jamais negando a sua origem bandeirante. (CONTI, 2001,p.11).

A esta citação soma-se a carta de Mário de Andrade, enviada a João Batista Conti, publicada no Diário Popular de 21 de janeiro de 1938, a qual ilustra o espírito de preservação da cultura e o ufanismo por Atibaia:

A sua terra já me atraia muito pela beleza de suas paisagens e amabilidade do seu clima, porém agora a considero ainda muito mais, por ver que é uma legítima fonte das tradições do nosso Estado. Estas tradições devem orgulhar Atibaia, tanto como a perfeição do seu clima, porque se este nos conforta o corpo, nada melhor que as tradições para retemperar a saúde de nossa alma brasileira, todo dia adoecida pelos micróbios do rádio, do jazz, do tango e das guerras internacionais.(MARIO DE ANDRADE, 1938 apud CONTI (2002). 
Da obra de João Batista Conti, no que diz respeito aos fatos que marcaram a fundação da cidade há correspondência com a pesquisa de Beatriz W. Cerqueira Leite. As terras existentes no Século XVII nessa região, situadas entre as vias que levavam ao Sertão de Cataguases, era habitada por "índios ferocíssimos", denominada Atibaia e situada à margem de um rio caudaloso. Entre os exploradores do sertão de Atibaia, havia um potentado paulista de nome Jerônimo de Camargo, que havia sido juiz na Vila de São Paulo e mais tarde por questões políticas desapareceu da vila e embrenhou-se no sertão. A história de Jerônimo de Camargo e sua instalação nas terras de Atibaia, está relacionada com a luta entre os Pires e os Camargos que ocorreu entre 1640 até 1722, conforme contada por Pedro Calmon com base nos documentos da Nobiliarchia Paulistana.

Em 27 de junho de 1769 através de Portaria, o Morgado de Mateus, elevou a freguesia de Atibaia, à categoria de vila, nomeando os primeiros oficiais da câmara, cuja posse se realizou em 12 de março de 1770. "Com a nova organização Atibaia passou a ter uma vida mais tranquila. Com sua casa da câmara e cadeia pode tocar a vida e cuidar do seu desenvolvimento", segundo Conti (2002, p. 18).

Atibaia sempre esteve ligada aos grandes acontecimentos. As revoluções do Século XIX na Europa fizeram eco por aqui, entre elas a Revolução Liberal do Porto, em 1820, ocasião em que o povo declara seu apoio ao monarca português D. João VI. Em praça púbica, as companhias milicianas de infantaria e o povo, assim se manifestaram, conforme Conti

“Juro as bases constitucionais decretadas pelas Cortes Gerais
extraordinárias, constituídas em Lisboa. Juro obediência à sua
Majestade o Sr. Dom João VI, rei constitucional do Reino Unido de
Portugal do Brasil e Algarves, juro outrossim de vigiar pela exata e
pronta execução das leis existentes, de promover todo o bem desta
província em particular e da Nação em Geral, juro obediência ao
Governo, bem assim a Deus nosso Senhor(Atas da Câmara
Municipal de Atibaia - CONTI, 2002, p.20)

De forma contraditória, o movimento da Independência e o Grito do Ipiranga tiveram em Atibaia uma recepção também entusiasmada. A população reúne-se em praça pública, a 5 de outubro de 1822, levando cada pessoa uma flor verde, dentro de um ângulo em ouro, com a legenda "Independência ou Morte", pregada no braço esquerdo, e declaram que : "de vontade de todos estavam prontos a manter a liberdade, independência e a Sua Alteza o Príncipe Regente e o aclamaram a viva 
voz", a 7 de outubro reúnem-se novamente para estabelecerem os festejos que deveriam realizar-se no dia da aclamação do primeiro imperador, que foi aclamado por muitas vozes: " (CONTI, 2002).

De forma semelhante, por ocasião da 1a․ Assembléia Constituinte e promulgação da Carta Constitucional de 1824, a 12 de abril, na Igreja Matriz de Atibaia, em missa solene foi jurada a Constituição Liberal nestes termos: "Tudo em ação de graças por passar o Projeto de Constituição feito pelo Conselho de Estado, e mandado fazer pelo Senhor Dom Pedro I, Imperador Constitucional e perpétuo defensor deste Império do Brasil" (Conti, 2002).No segundo reinado, representantes da população de Atibaia enviaram mensagens de congratulações a Dom Pedro II, pelo casamento com Dona Tereza Cristina:

\begin{abstract}
"Atibaia, possuída do maior entusiasmo com o feliz consórcio de sua Majestade, reconhece de seu rigoroso dever congratular com tão grande motivo, pelo que vem por aos pés de sua Majestade os sinceros votos de amor, fidelidade e profundo respeito que tributa a Vossa Majestade e que não cessará de oferecer fervorosas orações ao supremo pela conservação da preciosíssima vida e glória de sua Majestade, e , pelos seus representantes, manifesta esses seu sentimento de lealdade e adesão." (CONTI,2002, p.21).
\end{abstract}

Em 22 de abril de 1864, Atibaia foi elevada à categoria de cidade. Em sessão solene na Câmara Municipal, vereadores e povo participam de cerimônias e declaram a posse da cidade com os dizeres: "Está inaugurada a cidade de São João Batista de Atibaia".

Atibaia contribuiu para as idéias abolicionistas na pessoa do célebre juiz municipal Dr.Antônio Bento de Souza e Castro, que mereceu a publicação de uma coletânea de textos que contam a sua história. Figura polêmica, reorganizou o partido conservador na cidade, abolicionista fez parte do grupo dos caifazes,foi responsabilizado pela libertação de escravos africanos depois da lei de 1831 e enfrentou tenaz perseguição dos poderosos liberais de Atibaia.

No movimento republicano Atibaia teve participação importante, teve representante no 1‥Congresso Republicano Provincial. Proclamada a República aconteceram passeatas pela cidade e a 21 de novembro a Câmara Municipal, com maioria de vereadores liberais reuniu-se para "proclamar a república no Brasil". Com 
a República iniciou-se uma série de melhoramentos locais, conforme Conti (2002, p.23). Surgiu o primeiro jornal, O Itapetinga, em 1890.

No decorrer do Século XX a agricultura cafeeira, predominante no século XIX, deu lugar à diversificação de culturas. Atualmente pode-se afirmar que predomina em Atibaia uma intensa atividade rural, o que explicaria em parte, a existência de um número expressivo de escolas rurais isoladas, a atividade econômica principal é a lida com a terra, seja no cultivo de hortaliças, frutas ou criação de animais de corte predominando as granjas de produção de ovos e aves para abate.

O cultivo de plantas e flores ornamentais também é muito importante, desenvolvendo-se um vasto campo de pesquisas para transformação genética de flores, sobretudo orquídeas e flores que são comercializadas em São Paulo e Campinas, bem como para exportação. Essa tradição agrícola é remanescente do período imigratório que aconteceu na região, ao final da segunda guerra mundial, com marcante presença de italianos e japoneses, que ainda hoje mantém o monopólio da posse da terra e produção: Os descendentes de italianos predominam no cultivo de frutas de mesa, tais como uvas, morangos e pêssegos e os descendentes de japoneses dominam a produção de flores, plantas ornamentais e morangos.

\subsection{A educação escolar em Atibaia-SP.}

A respeito da existência de escolas no município de Atibaia, os estudos realizados pelo atibaiano João Batista Conti (2001) apontam que o primeiro movimento de preocupação com a educação escolar surgiu em 1814 "quando a câmara municipal reclamava a falta de professor para a cadeira de latim que fora criada". Essa vaga foi preenchida em 1815 pelo Padre Manoel Batista de Sá Rangel, no mesmo ano foi nomeado Simão Barreto Félix como professor régio de primeiras letras. Em 1820 dois professores régios exerciam o magistério em Atibaia. Estes são os registros mais antigos sobre a existência de escolas em Atibaia na primeira metade do Século XIX. 
A 14 de julho de 1851 foi criada a primeira escola feminina local e foi nomeada para dirigi-la a professora Guilhermina de Toledo Ordonhez. O professor de primeiras letras era Francisco de Castro Moreira que foi substituído pelo Prof. Antonio de Toledo Ordonhez. Em 1865 foi implantado mais um colégio feminino dirigido por Madame Arpenans onde era ministrado o ensino de português, francês, música (canto e piano), desenho e prendas domésticas. Em 1873 eram professores públicos Francisco Compton D'elboux e Barbina de Toledo. No recenseamento de 1886, encomendado pelo governador da província, consta que em Atibaia, existiam seis escolas masculinas, com 132 alunos e duas femininas, com 52 alunas. (CONTI, 2001, p. 39).

Em 06 de abril de 1903 foram iniciadas as obras de construção do Grupo Escolar, com recursos obtidos através de uma lei denominada "Lei dos Fogões". O projeto de lei foi apresentado à Câmara Municipal, aprovado o projeto foi criado o imposto denominado "fogões", tratava-se de um recolhimento de $3 \$ 000$ réis sobre os fogões: "compreendendo-se o local em que se preparam ao lume os alimentos de cada domicílio". A redação da citada lei era a seguinte:

Parágrafo $1^{\circ}$. - Se em um mesmo domicílio residir mais de uma
família, utilizando-se do mesmo fogão,o imposto será cobrado
repetidamente na proporção do número de famílias domiciliadas;
Parágrafo $2^{\circ}$. - Compreende-se por domicílio para o efeito de
exiquibilidade do presente imposto, a casa em que habitualmente
residem os indivíduos;
Parágrafo $3^{\circ}$. - Nos prédios alugados ou arrendados o imposto será
pago pelo arrendatário ou locatário;
Parágrafo $4^{\circ}$. - O imposto sobre os fogões é extensivo ao município.
O produto de arrecadação será aplicado na construção de um prédio
para o Grupo Escolar desta cidade.

A obra foi concluída em 1904 e o prédio foi doado ao governo estadual em janeiro de 1905,por meio de escritura e as aulas iniciaram-se em fevereiro do mesmo ano. Foram anexadas as escolas de Atibaia no Grupo Escolar, denominado José Alvim, que então era presidente da Câmara Municipal e que havia apoiado a criação do imposto "fogões". Este tributo foi a forma encontrada para que os custos com a instalação do Grupo Escolar fosse arcado pelas famílias residentes no município de Atibaia. 
A mesma Câmara Municipal tornou obrigatório o ensino primário no município, através da lei municipal $n^{0} 100$, de 03 de novembro de 1906,como registra Joviano Silveira, no trabalho intitulado "O ensino obrigatório em Atibaia".

No final do século XIX e começo do século XX havia quatro escolas na zona urbana, dirigidas pelos professores Edmundo Malaquias de Almeida Lisboa, Eugênio Augusto de Toledo, Risoleta Ceslau de Moura e Maria da Glória Enrique Lisboa. Estas foram anexadas e formaram o Grupo Escolar José Alvim, conforme já apontado. Existiam, ainda, segundo Conti (2001, p.39), muitas outras escolas espalhadas pelo município, o que nos dá pistas sobre a existência de escolas rurais desde aquela época, embora não se tenha conseguido a documentação oficial que comprove tal existência.

Para entender ao menos em parte esta questão, buscou-se fazer uma relação entre a história da educação em Atibaia com os estudos realizados por Demartini (1988, p.72) sobre o funcionamento do sistema educacional no Estado de São Paulo na Primeira República. Na ausência de documentos oficiais sobre o tema, esta autora realizou pesquisa com base em depoimentos de ex professoras que atuaram no interior e no litoral do Estado, em sítios, fazendas e vilas à época dos grandes cafezais que predominavam na lavoura monocultora.

A pesquisa apontou que as escolas situadas em propriedades rurais pertenciam geralmente ao Estado, eram escolas isoladas todas consideradas rurais. A existência de escolas nas fazendas sempre dependia da vontade do dono das terras, do seu interesse político e dos grupos de poder em disputa. No caso, sempre levava a melhor o latifundiário que era também o chefe político local, pouco importando as normas do Código de Educação existente nessa época.

A regra geral era que para criar uma escola, havia a necessidade de solicitação ao governo estadual, por parte das autoridades escolares, de fazendeiros, sitiantes ou posseiros sempre que existisse no mínimo 40 crianças de ambos os sexos, em um raio de dois quilômetros. Esse pedido deveria ser acompanhado de documentos tais como censo, solicitação de prédios, pensão para professores, meios de transporte e tipos de unidades: escolas agrupadas, isoladas, mistas, femininas, masculinas, urbanas, distritais, rurais. Nem sempre o que pesava mais era a existência de crianças mas sim a vontade do fazendeiro em criar ou não uma escola em sua fazenda. Conforme depoimento colhido por Demartini (1988) 
as escolas sempre foram criadas pelos deputados e grande parte dessas escolas eram criadas porque os prefeitos solicitavam, e não pelas informações das autoridades escolares.... Sempre foi assim em outros tempos... porque o fazendeiro vai ao governo, vai à secretaria do governo e diz ao secretário: - eu quero que você coloque uma escola em tal lugar. O governo cria a escola ......antigamente, bastava o pedido do fazendeiro, do chefe político local para a escola ser criada..... antigamente se não existissem alunos, a escola era criada da mesma maneira. O professor que era nomeado prá lá não tinha jeito de manter a escola. Era obrigado.... chegava, abria a escola e não tinha matrícula mínima e tinha que ser removido prá outro lugar onde tivesse alunos. Quer dizer, o professor tinha que andar de lugar, em lugar, até se localizar, até ficar firme. (DEMARTINI, 1988, p.77)

Esse depoimento evidencia que os critérios para criação de escolas, se davam para atender a interesses pessoais dos fazendeiros em situações variadas, quer seja para atender pessoas da família e parentes do fazendeiro ou para que a filha formada pudesse lecionar. Assim, a existência ou não da escola ficava muito mais na dependência da política local, do que de uma política educacional propriamente dita. Havia também razões de ordem econômica visando a valorização da fazenda e a fixação dos colonos e dos camaradas, mão de obra fundamental para a lavoura e ainda os interesses políticos locais, quando a escola era elemento de disputa entre grupos políticos rivais.

Nas propriedades menores, os sítios, cujos proprietários fugiam aos padrões do poder local, sob domínio de latifundiários, a existência de crianças a serem escolarizadas e a obrigatoriedade da educação primária, levavam as próprias famílias a arcarem com os custos da montagem da escola, situação encontrada nesta pesquisa, nos bairros do Portão e da Água Espraiada.

No que se refere à criação de escolas rurais com a denominação, funcionamento e organização que permanece até nossos dias, temos notícia da instalação das primeiras, a partir da década de 1940, estas estavam localizadas em espaços improvisados e cedidos por particulares, donos de sítios ou fazendas.

Dados do censo 2010 indicam uma população de 126.603 habitantes, sendo que 11.374 vivem na zona rural, um total de 14 escolas rurais que atendem a educação infantil e ensino fundamental $1-\left(1^{\circ}\right.$ ao $5^{\circ}$ ano $)$, quatro escolas rurais que oferecem o ensino fundamental II (6ํㅜ ao 9ํano) e o Ensino Médio. 
Entre as escolas rurais, está a Escola Estadual Professora Zilah Barreto Pacitti, situada no Bairro do Portão, local desta pesquisa. Esta escola, passou por todas as transformações decorrentes das alterações legais ao longo do final da década de 1960, contidas na Lei 5692/71 até a edição da atual LDB (Lei 9394/96). A história desta escola foi objeto de pesquisa documental realizada no decorrer da elaboração desta dissertação, conforme apresentaremos no capítulo 4.

\subsection{A história dos bairros contada pelos moradores.}

Em 1993, ano em que Atibaia comemorava 348 anos, os estudantes da $6^{a}$ série do Ensino Fundamental da Escola Zilah Barreto Pacitti, questionavam porque não havia nada escrito sobre a história dos bairros onde residiam e por que eram obrigados a desfilar em Atibaia. Os adolescentes percebiam, mais que os professores e equipe da escola, que haviam muitas contradições entre a vida que levavam no bairro e a vida na cidade, onde só iam em ocasiões especiais.

Nessa época havia na escola, um grêmio estudantil, muito atuante e que não aceitava nenhum projeto que não fosse discutido por eles. Assim é que a equipe da escola se viu na obrigação de elaborar um projeto de pesquisa, que ficou sob a orientação do professor de história e da diretora, também historiadora.

O projeto ultrapassou os limites da escola, foi então feita uma edição especial do jornal local, incluindo o projeto dos estudantes nas comemorações do aniversário da cidade. Em 24 de junho, data do aniversário de Atibaia, os estudantes desfilaram com faixas contando a história do bairro do Portão e da Água Espraiada. Esses dois bairros foram escolhidos para a realização desta pesquisa pois até hoje apresentam as características apontadas por Antônio Cândido em seu clássico Os Parceiros do Rio Bonito.

(...) os bairros são um agrupamento mais ou menos denso de vizinhança, cujos limites se definem pela participação dos moradores nos festejos religiosos locais. Quer os mais amplos e organizados, geralmente com o apoio na capela consagrada a determinado santo; quer os menos formais, promovidos em caráter doméstico.(CÂNDIDO, 1997, p.71). 
A apreensão do cotidiano, a maneira como vivem e convivem as pessoas que não tiveram condições de influenciar diretamente a produção dos documentos oficiais é deixada de lado na produção do conhecimento histórico, de uma maneira geral. Assim, para construir a história do bairro do Portão e do bairro da Água Espraiada, locais das escolas estudadas nesta pesquisa, recorremos aos depoimentos de antigos moradores, que foram colhidos, registrados e fazem parte do acervo de memória do Bairro e da escola.

A história dos bairros relatada pelos moradores, quando confrontada com a história oficial de Atibaia registrada em livros, evidencia as contradições existentes entre o que é valorizado pela classe dominante e a cultura do povo.

As informações foram obtidas por meio de conversas com moradores mais antigos do bairro e anotadas em um caderno de campo. Chama atenção a preocupação dos narradores em buscar na memória a data precisa dos acontecimentos e das mudanças na economia do lugar que provocaram rupturas em seus modos de vida. Essas lembranças, relatadas por pessoas com pouco ou nenhuma escolarização, evidenciam que o trabalho é um dos eixos básicos de suas identidades, formada na labuta do cotidiano. É o trabalho que lhes pauta a trajetória e é por isso o princípio da ordem e da organização do cotidiano.

No bairro do Portão e no Bairro da Água Espraiada, até hoje pode-se verificar a presença marcante de caipiras, entendidos aqui como o grupo social ou a pessoa portadora dos traços da cultura caipira, tal como a tratou Antônio Cândido (1971).

É esse autor que permite o rompimento do estereótipo, que faz com que o caipira seja visto como uma pessoa isolada, que não sabe falar, sem higiene, analfabeto e morador de ranchos espalhados pelas roças. Assim a figura do caipira e o modo preconceituoso como ainda é visto, até os dias de hoje, serviu à ideologia que considera o campo lugar de atraso e ignorância enquanto a cidade seria o lugar de progresso onde residem as pessoas cultas e bem de vida.

Antônio Candido (1971) desvela essa ideologia e mostra que o isolamento do caipira é apenas aparente, a vida social das famílias que vivem no campo é intensa, seus habitantes têm como referência o bairro, onde se vive uma cultura que $o$ 
distingue dos demais grupos e onde se organizam as relações sociais com a vizinhança, estabelecendo laços com base na ajuda mútua.

Os caipiras são em sua origem, o resultado da miscigenação que ocorreu ao longo dos Séculos XVI, XVII e XVIII, sendo que no final do Século XVIII essa cultura já estava configurada com todas as suas características, constituindo o que Maria Isaura Pereira de Queiroz chama de civilização caipira - a forma mais antiga de civilização e cultura da classe rural brasileira, formada desde os primeiros tempos da colonização. (CAMPOS, 2003, p.101).

Foram encontrados traços da cultura caipira que ainda subsistem no modo de viver de parte dos moradores nos bairros que foram estudados nesta pesquisa, costumes antigos foram ressignificados, como é o caso dos mutirões.

A ajuda mútua foi, e ainda é, um valor que persiste entre a população caipira de Atibaia. O mutirão é um sistema de trabalho singular porque diferente do sistema de empreitada ou pagamento em dinheiro por dia trabalhado, é quase uma comemoração e termina sempre em festa, onde o dono da roça oferece comida e bebida aos participantes.

Se antigamente os moradores do bairro reuniam-se em mutirões para dar conta do plantio e colheita dos produtos agrícolas, conforme relatou um morador do Bairro da Água Espraiada, "meu pai plantava feijão, plantava arroz, milho, chegou a plantar batata, chegou a plantar mandioquinha, tudo para sobrevivência, ervilha, meu pai plantava, fazia mutirão para colher ervilha".

Com a perda da terra a partir dos anos de 1960 e impossibilitados de praticar a agricultura, atualmente os mutirões acontecem na construção ou ampliação das casas, quando o filho ou filha vai casar-se. O convite é feito pelo noivo ou pai do noivo ou noiva nas tarefas que exigem um grupo maior de pedreiros e serventes, como a construção dos alicerces ou na construção dos telhados ou lajes, visto que "fazer concreto para bater a laje da cobertura das casas exige muito esforço e trabalho braçal em equipe com extrema sintonia, sob o risco de se perder o material" conforme nos informou um morador do Bairro do Portão.

Quando o trabalho termina, os mutuários colocam uma bandeira de pano no ponto mais alto da construção, isto significa que o trabalho acabou e estão 
esperando a comida, a bebida e os festejos em comemoração. Os moradores que não participam ficam mal vistos perante os demais.

Entre as mulheres permanece o costume da pamonhada, que acontece na ocasião da colheita do milho, ainda verde. Reúnem-se os parentes ou vizinhos para a atividade coletiva, as crianças também são incluídas no trabalho mais leve, como tirar os estigmas (cabelos) das espigas de milho. A atividade demora praticamente $o$ dia todo, desde a colheita do milho no sítio ou chácara, acender o fogo se houver fogão à lenha, preparar o tacho onde serão cozidas as pamonhas, ralar o milho, o que demanda apenas força nos braços. Mas temperar e embrulhar pamonhas são trabalhos que exigem habilidades mais complexas.

O compadrio e apadrinhamento ainda são bastante valorizados nos dois bairros estudados, tanto para batizados como para casamentos. Os compadres passam a tratar-se por Senhor e Senhora mesmo entre amigos ou parentes e entre as obrigações está a proteção e cuidado com as crianças e aconselhamento dos casais afilhados. Nos batizados, os pais da criança oferecem um almoço para os padrinhos e no casamento os padrinhos ajudam com as despesas da festa ou até mesmo na preparação do enxoval, vestido da noiva ou terno do noivo.

Os moradores se unem também para a organização das festas religiosas dos bairros, como a do Santo Padroeiro, a via-sacra durante a quaresma, as vigílias na semana santa e as novenas e visitas aos presépios que fazem parte dos festejos do Natal e a Reza de São Gonçalo.Para a realização das festas é escolhido um festeiro que fica responsável por angariar fundos e organizar o evento. $O$ festeiro é escolhido pelo grupo, levando-se em conta a sua liderança na comunidade e experiência em organizar as festas.

Os depoimentos dos moradores mais antigos do Bairro do Portão e do Bairro da Água Espraiada permitem fazer um panorama da organização econômica e social predominante nesses bairros, os relatos são de assuntos variados porque foram colhidos de forma que as pessoas, já idosas, pudessem falar livremente de suas lembranças. Mostrar fotos, objetos e utensílios que haviam guardado do tempo em que não havia eletricidade e a água para uso doméstico era buscada em minas e bicas. As roupas eram lavadas em córregos e boa parte dos utensílios eram feitos de forma artesanal, objetos como peneiras, balaios e cestas são até hoje feitos por 
alguns moradores que ainda detém a técnica da cestaria, de origem indígena. As panelas eram feitas de barro, lamparinas eram feitas com latas usadas, havia panelas de ferro, moinhos para grãos e ferro de passar roupa à brasa.

O Bairro do Portão era praticamente auto-suficiente tanto do ponto de vista econômico como do ponto de vista social. Os relatos colhidos revelam uma atividade econômica e vida social intensas. Essa autonomia produzia um certo orgulho e nostalgia por parte dos moradores em não dependerem de quase nada para 0 abastecimento local. Os relatos feitos demonstram a autonomia dos bairros rurais em relação às cidades: "Nós plantávamos para comer e ainda sobrava muito para vender (...) Na década de 20 se transportava com tropas de burros os produtos da região. Esses produtos - feijão, batata, café e milho, eram comercializados na cidade", relatou o Sr. Ângelo Poloni,

No bairro não existe cemitério até os dias de hoje, sendo que os sepultamentos ainda são feitos na sede do município. Interessante observar que os velórios eram realizados nas casas e havia o costume de se colocar uma cruz na propriedade para cada um dos falecidos. Como afirma, Dona Geralda Poloni: "Os moradores iam à cidade apenas para enterrar seus mortos no cemitério, O cemitério era em Atibaia e nós fazíamos o transporte dos mortos em redes ou macas carregadas pelos parentes do morto."

O comércio local se resumia a existência de uma venda, onde compravam os produtos que não se conseguia extrair da terra. Dona Elisa Santana contou que: "Ângelo Poloni veio da Itália, teve a primeira venda, aberta em 1901, ele também foi quem comprou o primeiro carro, em 1927".

Também o relato do Sr. Aparecido Bizarri comprova a auto-suficiência do bairro do Portão, que produzia alimentos para vender em São Paulo. Nesta entrevista percebemos a necessidade de provocar as memórias.

- Plantava de tudo, para sustento da casa tudo, feijão, arroz, abóbora, batata doce, mandioca, mandioquinha, milho, café. Eu lembro uma época que na minha casa só comprava querosene e sal, só. O Café fazia com café que plantava, colhia, secava e socava no pilão para tirar a casca, depois torrava na panela mesmo e moía para fazer o pó de café, adoçava com garapa de cana., fervia a garapa e passava o café no coador de pano.

- Plantava cana também?

- Plantava cana também. 
Ele fazia a Garapa?

- Fazia garapa.

Você se lembra como era feito?

- Tinha um cilindro, um moedor daquele de mão, colocava a cana lá, e fazia a garapa, adoçava, fazia a rapadura, doce, de tudo que era fruta fazia o doce.

Seu pai vendia as coisas, ou não?

- Vendia, ele chegava a colher às vezes, um caminhão de batata.

Vendia para São Paulo?

- Isso, vendia para São Paulo.

- Quem levava, era o Chico Prado, que é pai do Baixinho, pai do Milton, e meu pai as vezes ia junto no caminhão. E aí ele ficava lá, às vezes um dia, dois, e na hora que vendia tudo ele pegava o dinheiro e vinha embora.

No Bairro da Água Espraiada a atividade principal também era a lavoura de cereais e legumes, cultivada em pequenas propriedades, para o consumo da família e venda dos excedentes, conforme nos relatou o Sr. Benedito Santana, conforme foi sendo interpelado:

O que vocês plantavam no sítio?

- O meu pai plantava, milho, feijão, tinha uns 150 pés de café, que era o café pra gente beber, não é? minha mãe que lidava com o café, até chegar ao café em pó.

Só para consumo?

- Só pra consumo, é...e também para vender, era o jeito de conseguir algum dinheiro...

Mas vocês vendiam?

- Vendia, ia tudo para São Paulo, pro mercado de São Paulo, na época devia ser...não sei se já tinha o Ceasa...

E vocês levavam ou quem que levava?

- Tinha uma pessoa, de Terra Preta, que carregava no caminhão e levava para São Paulo, e meu pai ia junto, para fazer os negócios dele lá. Mas quem carregava era um pessoal que morava em Terra Preta, faziam este transporte da mercadoria que $o$ meu pai produzia...

.....eu sei que meu pai fazia isso, ele, as vezes ele ia para São Paulo, ficava lá dois, três dias, quando ele acabava de vender a mercadoria ele voltava pro sítio, com o dinheiro né que ele arrecadava lá.

Dona Ditica reforça essas memórias e nos relatou que "As pessoas viviam da lavoura de café e batata de1930 a 1950. A fabricação de carvão era muito grande...".

“O Carvão apareceu em 1927 e acabou em 1956”, conta o Sr. Zelão Pomba, em 1950 foi proibida a derrubada das matas, E, em 1953 a estrada Fernão Dias foi aberta. 
Após 1888 vieram os imigrantes, a primeira família a chegar ao Bairro foi os Poloni, para trabalharem no café. Depois Angelo Poloni deixou o trabalho na fazenda e montou um armazém, comprou uma tropa de burros e começou a fazer o transporte de gêneros.

Na década de 30 o café foi acabando, o povo do bairro começou a viver da derrubada das matas para fazer carvão, em 1950 foram oficialmente proibidas as derrubadas e a população voltou a dedicar-se quase que exclusivamente a agricultura de gêneros variados para consumo e venda em feiras e mercados. Em 1953 começou a construção da rodovia Fernão Dias e muitos moradores do Bairro foram trabalhar na construção da estrada de rodagem.

O cotidiano das famílias caipiras também era marcado por fortes características culturais, expressas na forma como se divertiam e como entendiam as lendas: "Saci existi sim! E vinha jogar pedra na gente"; as danças " $A$ dança do catiró é uma das danças antigas"(Zelão Pomba); "o divertimento era feito em qualquer lugar: nas casas dos outros, com violão, sanfona, pandeiro e batida de colher" (Elisa Serafim Santana).Os divertimentos eram samba, quadrilhas, congadas, bandeira do Espírito Santo e Folia de Reis (Antonio Pereira). Segundo Aparecido Bizarri, eram os jovens quem promoviam os bailes: "em baile a gente só foi divertir mais ou menos quando tinha uns dezoito anos (...) a gente fazia os bailes na nossa casa, um dia na casa de um, outro dia na casa de outro (...) para a cidade eu comecei a ir já com uns vinte anos mais ou menos”.

A religiosidade também era um fator que agregava a comunidade, sendo que segundo os relatos, "o primeiro padre veio em mais ou menos 1930, e se chamava Francisco"(José Aparecido Santana);“Quando o primeiro avião passou no céu o povo pensou que era uma cruz como sinal de Deus" (Dona Veríssima); "Tinha uma igreja de Santa Cruz que era feita de palha. Em 1926 construíram a igreja de tijolo, no dia 02 de maio, sempre tinha festa” (Sr. José Santana) “Em sexta feira maior, à meia noite, as pessoas iam em procissão para Atibaia”. (Zelão Pomba).

Segundo Aparecido Bizarri: "Tinha muita [reza], muito rezador aqui, reza de São Gonçalo, Reza na casa das pessoas. O enterro e os velórios, também eram nas casas. Eu não cheguei a ir, mas minha mãe conta que tinha um monte de velório que levava daqui a Atibaia a pé.Quando chegava em abril, até agosto tinha quase 
toda semana, muitas rezas. Terço nas casas, no dia da colheita, sempre tinha um terço e depois todo mundo ajudava na colheita, principalmente quando era milho. Aí dava comida, a gente cantava"

Outros traços da cultura e das condições econômicas da época, são relembradas pelo modo de se vestir ou morar: "As roupas eram feitas pelas mães, de algodão ou saco" (Geraldina) "As casas eram de pau a pique e tábuas. As casas de ripas, o telhado era de canudos cobertos de sapé" (José Pereira Santana). "A casa não tinha luz, não tinha nada, o chão era de terra, fogão a lenha, não tinha banheiro, nada. Nem banheiro no mato tinha, um ia em um lugar, o outro ia no outro, disso eu lembro bem. Era muito simples mesmo né". (Aparecido Bizarri). "Os remédios eram feitos com ervas. Quando machucava o braço era enfaixado com taquara" (Luiz Rodrigues Dias).

A alimentação era diversificada e percebe-se também a relação de ajuda mutua entre os caipiras, como afirma Aparecido Bizarri: "Quando matava porco, a mesma coisa, fazia um prato de carne, levava pro vizinho e quando eles matavam eles traziam para a gente também. [Não tinha carne de gado], era mais porco e galinha mesmo (...) eu nem lembro de ter bife. Acho que até uns quinze anos eu nunca tinha comido bife. (...) Mas tinha, ovo, mandioca, ervilha, farinha de trigo, milho, virado. Tudo era plantado, cebolinha, cebola, batatinha."

A influência dos imigrantes italianos pode ser notada na alimentação: "era tudo no costume da Itália, tinha de tudo dentro de casa. O nhoque por exemplo, no começo meu pai que fazia o nhoque, minha mãe também sabe fazer mas ela aprendeu com meu pai. Que era um nhoque de batata doce, não de batatinha. Massas, pastel, pão, bolo, broa, tudo isso ele fazia, com mandioca, com fubá."

A partir de 1960, as atividades econômicas se diversificaram e áreas antes destinadas à lavoura de produtos variados, tornaram-se chácaras de recreio. Isso se deveu em parte pela facilidade de acesso entre o Bairro e o centro da cidade e da capital do Estado com a construção da rodovia Fernão Dias. A rodovia serviu como catalisadora do processo de expansão dos setores ligados à construção civil, notadamente as olarias. Tal expansão trouxe famílias oriundas do sul do estado de Minas Gerais, atraídas pela perspectiva de trabalho. 
Essas famílias constituíram um núcleo habitacional significativo a "Vila dos Mineiros". As famílias mineiras chegaram na década de 1970, conforme o relato de Josué Cosme:

"Nasci na cidade de Natércia, em Minas Gerais. Uma cidade bem pequena, de uns 3500 habitantes. Cheguei aqui com meus pais com três anos de idade, em 1970, se não me engano... Tenho um irmão mais velho, o Daniel, que também nasceu em Natércia, minha irmã Jesuana, a Zana e meu irmão Ismael, o Mael, já nasceram aqui no Bairro do Portão...

Meus avós, pais do meu pai já tinham vindo embora, a situação em Minas estava muito ruim... o lugar era muito pobre... todos trabalhavam na lavoura de café... aí o café entrou em decadência... meu pai era carreiro, tocava os bois do carro de boi... ficaram todos sem trabalho, chegamos a passar fome, então viemos para o Bairro do Portão, onde viviam meus avós, que trabalhavam no Alambique do Dr. Jacinto, no plantio e corte de cana... fomos morar com eles e meu pai arrumou trabalho no alambique também.

Depois o Seu Lazico cedeu uma casinha para a gente morar, acho que desde aquele tempo morar com sogra não dava certo... mudamos e minha mãe arrumou um emprego de cozinheira... aí as coisas começaram a melhorar, segundo ela conta.

Mais tarde, começou no Bairro um movimento grande de construção civil, com a construção de muitas obras no Clube da Montanha... meu pai começou trabalhar como servente de pedreiro e aprendeu a profissão de pedreiro e depois carpinteiro...A vida era muito simples, a gente comia o que plantava: chuchu, abóbora, mandioca, milho e farinha de milho, no Alambique havia também uma fábrica de farinha de milho, além da fábrica de pinga."

Na década de 80 começaram a chegar ao Bairro do Portão trabalhadores vindos do Estado do Ceará, vinham sem as suas famílias, ao contrário dos trabalhadores mineiros, conforme nos contou Aucinete, uma das pessoas que migrou, frequentou a escola e ainda reside no bairro.

“Nasci em Limoeiro do Norte, tenho 38 anos, vim de lá com 10 anos de idade, faz 28 anos que eu moro aqui no Bairro do Portão... 
Meu pai trabalhou aqui no Bairro durante muito tempo, e a minha mãe ficava lá, daí eles resolveram que iríamos ficar todos juntos, então resolveu trazer todo mundo pra cá. Veio eu, meu irmão mais velho, meu irmão mais novo, minha mãe e minha irmã que tinha três anos na época.... meu pai era marceneiro e carpinteiro e decidiu trabalhar aqui... porque lá não tinha condições de trabalho, era só mais na lavoura e tinha épocas do ano que não tinha como sustentar porque tinha muita seca também, e aqui tinha mais recursos, então ele vinha trabalhava, mandava dinheiro para a minha mãe, pra gente comprar as coisas pra gente... quem trouxe meu pai e os outros cearenses foi meu tio Idelfonso... da família do meu pai vieram quase todos os irmãos ... Assim... por cima acho que vieram umas 60 pessoas, só da nossa família... Primeiro veio meu tio Idelfonso, depois meu pai, mas meu pai já trabalhava naquela firma Camargo Correia em São Paulo, aí o meu tio traz um, depois traz outro, quando foi ver dentro do Bairro do Portão, já tinha outro bairro só de cearenses. Em Limoeiro do Norte da família só ficou um irmão do meu pai e meu avô."

Ao longo do período estudado os dois bairros rurais pesquisados configuraram-se como um lugar, aqui compreendido como uma construção social, fundamentada nas relações espaciais diretas, no cotidiano e na articulação entre a cooperação e o conflito. Para Moreira e Hespanhol (2007), compreender o lugar é considerá-lo em sua totalidade, ou seja, como um sistema de relações (subjetivoobjetivo, aparência-essência, mediato-imediato, real-simbólico), desse modo, é possível nos bairros rurais presenciar os pares dialéticos, o novo e o velho, o tradicional e o moderno, o exógeno e o endógeno, enfim, as mudanças e as permanências.

Ainda de acordo com Moreira e Hespanhol (2007), nos bairros rurais vão se impondo reajustes em todas as esferas da vida cotidiana, lazer, crenças, escola, poderes e sobretudo no trabalho. A perda da terra impõe ao trabalhador rural, o desenvolvimento de resistências, expressas na permanência de símbolos culturais como o mutirão, mas também Ihe são impostas as transformações decorrentes da perda da terra e a necessidade da escolarização para a adequação às novas formas de exploração do trabalho. 


\section{CAPÍTULO 4. A memória social: o que os depoimentos nos contam.}

O modelo econômico que se desenvolve durante a Ditadura Militar, intensificou a perda da posse da terra, liquidou os movimentos sociais e qualquer forma de organização política dos trabalhadores. Levados à fome e à miséria os camponeses não tiveram outra saída senão abandonar os bairros rurais indo para regiões periféricas onde houvessem condições mínimas de sobrevivência, através do assalariamento, e que possibilitassem o acesso à benefícios sociais, como a escola e a saúde.

Nesses locais, tão bem entendidos por Whitaker (2008) em que ocorre a fusão de um rural e de um urbano em desintegração, resulta um movimento dialético implicando desruralizaçao e ruralizaçao, desurbanizaçao e reurbanização, enfim um processo convulsivo marcado pela extrema perversidade do mercado. A educação escolar, mesmo fortemente ligada à ideologia autoritária e disciplinadora passa a ser vista como estratégia de não exclusão.

Em uma conjuntura em que o projeto de escolarização da população toma força, entre 1970 e 1980, a escola assume importância quase vital para a sobrevivência e inserção no mundo do trabalho e passa a funcionar como um mecanismo de resistência à exclusão social.

Enfim a luta pela sobrevivência torna-se uma luta política e desencadeia atitudes de resistência à dominação, como foi a luta pela instalação de escolas nos bairros do Portão e da Água Espraiada. Retomaremos aqui, a história das escolas, tanto narrada de acordo com as fontes oficiais, como também através dos relatos colhidos com os ex-estudantes.

Nesta pesquisa, realizada com ex-alunos de escolas rurais, pode-se apontar o surgimento da ação política no âmbito do cotidiano das famílias que lutavam pela instalação de escolas nos bairros rurais. A influência do político no âmbito do cotidiano evidencia as transformações ocorridas no funcionamento da sociedade como um todo.

Motivadas pela crescente predominância dos valores da sociedade industrial, as famílias rurais começaram a perceber que a existência da escola e a escolarização das crianças seriam indispensáveis para a sua sobrevivência, no mundo rural ou urbano, ambos em constante transformação. 
Isso ocorre porque nas famílias de maneira geral e no caso específico desta pesquisa, nas famílias rurais o trabalho teve desde sempre um papel estruturante na organização do modo de vida, daí a importância da aquisição dos códigos valorizados no mundo do trabalho, a leitura, a escrita, as operações matemáticas, exigências das novas colocações que estavam surgindo, principalmente no setor do comércio, tal como apontado por Martins (1971) e Brandão (1990).

O trabalho se configura como uma experiência comum à maioria das pessoas e é fator importante na constituição da identidade individual de cada um e da própria família, sendo fator essencial de colocação hierárquica na sociedade.Entre os trabalhadores o trabalho não só organiza a vida como também é fator preponderante de seu posicionamento na sociedade.

\subsection{A história da escola.}

Relatar a história de uma escola pública é sempre um desafio, principalmente em nosso país com pouca tradição em preservar a memória, de modo geral. Neste caso, foi um duplo desafio: ouvir as vozes daqueles que como eu vivenciaram a escolarização em uma escola rural e ao mesmo tempo intercalar as representações da pesquisadora com aquelas dos entrevistados; e, com esse envolvimento manter uma postura crítica ao vasculhar arquivos, ler documentos, selecioná-los e reviver o passado de professora e diretora da Escola Estadual Professora Zilah Barreto Pacitti.

Assim, para a construção deste relato histórico recorremos novamente às fontes documentais e às vozes dos ex-estudantes entrevistados durante a pesquisa de campo.

Começamos a pesquisa documental, tendo como referência os arquivos da escola. Foram consultados os livros de registro de matrícula, os livros de atas das visitas da inspeção/supervisão escolar, livros de registro de inventário material da escola e matérias de jornais locais sobre trabalhos realizados pelos alunos. A escola, embora não possua uma sala específica para arquivar os documentos, mantém uma funcionária que zela pelos livros e documentos antigos, pois muitas pessoas ainda procuram a secretaria da escola em busca de histórico escolar e declarações que comprovem a escolaridade. 
Recorrer à memória de ex-estudantes foi fundamental para escrever a história da escola e esclarecer alguns pontos controversos, como por exemplo a forma como a escola surgiu, conforme nos relatou Hilda Leite "lembro que quando a escola nasceu, ela nasceu no sítio da minha avó, Tereza Poloni, mulher do meu avô Ângelo Poloni, eles vieram da Itália, e enquanto ela era viva ainda, a escola funcionou (...) era o sítio ali, que agora é do Piracaia, aí quando o avô morreu, separou o terreno, dividiu (...) aquela parte da escola ficou para o Humberto Poloni, que era irmão dela.

O livro mais antigo que a escola guarda é um livro de Inventário, aberto em março de 1945, pelo Auxiliar de Inspeção Escolar de Atibaia. Conforme consta nos assentamentos, inicialmente era a escola era identificada como a Escola Mista do Sítio Ângelo Poloni, esta escolinha de sítio é que mais tarde se transformaria na escola pública, em funcionamento até hoje.

\section{Quadro1. Mobiliário e materiais pedagógicos da Escola Mista do Sítio}

\section{Angelo Poloni, em 1945.}

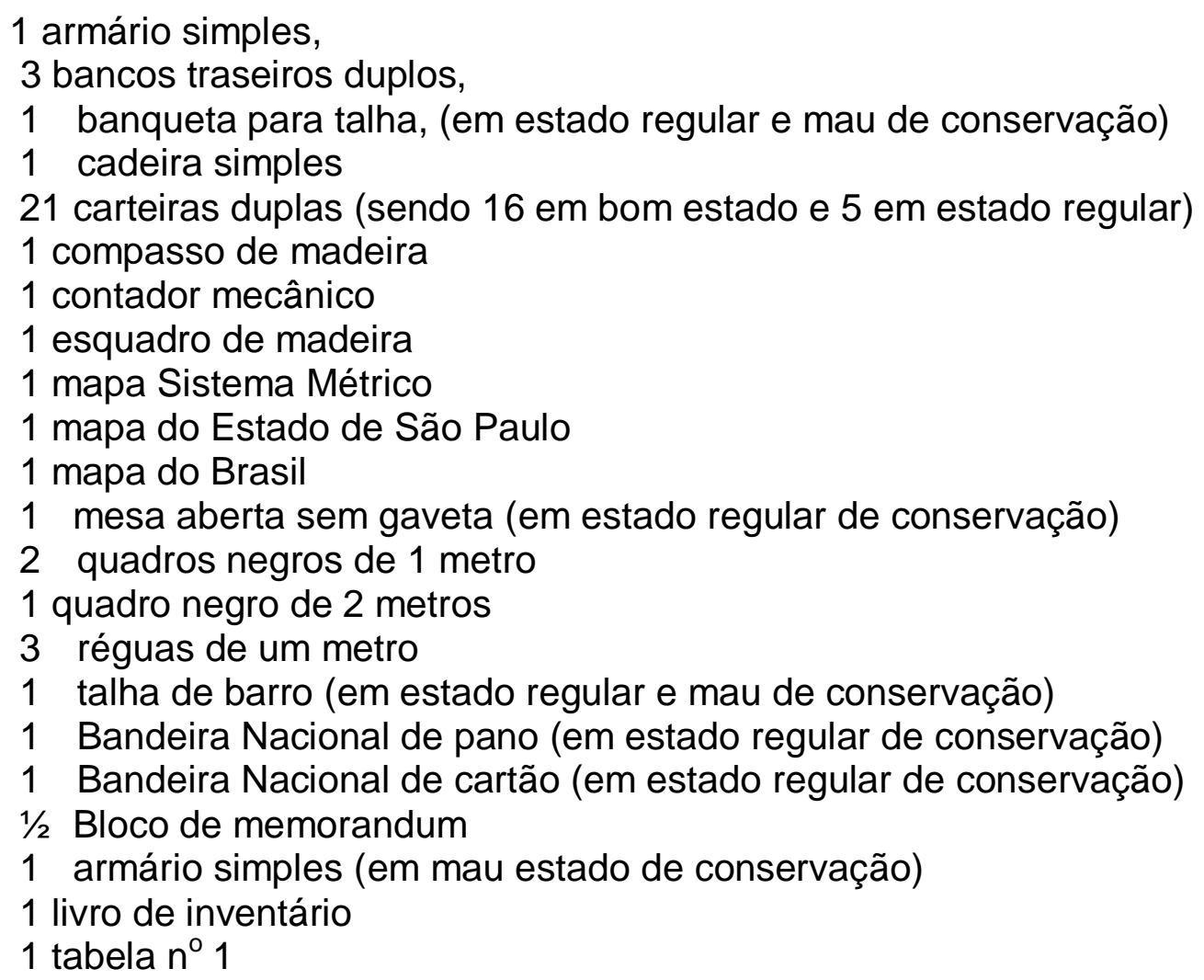

Fonte: Livro de Inventário (Org. pela autora).

Percebe-se na descrição dos materiais, que foram encaminhados pelo governo do estado por meio da delegacia de ensino de Bragança Paulista, que 
tratava-se provavelmente, pelo relato de estado de conservação do mobiliário, regular e mau, de materiais já utilizados. A escola rural era o lugar de descarte de materiais das escolas urbanas, conforme mostram os vestígios ainda presentes: carteiras antigas e armários reaproveitados e livros que ainda não foram descartados.

Em fevereiro de 1946 em nova visita à escola, o material existente era o mesmo, tendo sido dada baixa no armário que se encontrava "todo quebrado". Em abril de 1947, foi reposto um armário simples e novos materiais: Um livro de inventário, um livro de chamada, um livro de matrícula, dois livros de Termos de Visita.

Em julho do mesmo ano, acrescentou-se material didático destinado a professora e aos alunos: duas caixas de giz, 40 cadernos de cálculo, 35 cadernos de linguagem, 30 folhas de papel almaço, 24 lápis preto, uma lata de tinta vermelha e uma lata de tinta preta. No ano de 1948 o número de caderno de cálculo subiu para 40 e os de linguagem foram 60, 50 folhas de almaço e 36 lápis pretos.

A partir de 1948 ficou registrado apenas o mobiliário e matérias pedagógicos permanentes. Em 1954 muda-se o nome da Escola que passa a ser denominada Escola Mista do Bairro do Portão. Somente em 1962 foi dado baixa em um cadeira, um mapa sistema métrico decimal, mapa do Brasil, mapa do Estado de São Paulo, duas réguas de um metro e uma talha, encerrado o livro em fevereiro de 1962, pela Professora Oceania Oliveira. No ano de 1963, 1964, 1965 até 1966 nenhum material havia sido reposto. Nesse período a escola estava instalada em um imóvel cedido pelos herdeiros do sítio.

No ano de 1962 a escola foi transferida para outro sítio, mais distante. No livro Termo de Visita do período de 1962 a 1971, a ata de visita do Inspetor Escolar, lavrada em 17 de outubro de 1962 informa que:

"a professora declarou-me que a partir do próximo ano não pagará mais o aluguel da sala de aula, no valor de CR $\$ 600,00$ (seiscentos cruzeiros) mensais. Alegou que antes era gratuitamente, por pertencer a herdeiros e que o atual proprietário Sr. Humberto Poloni, vem, sucessivamente, solicitando aumento de aluguel, o que acha, que não é de sua obrigação, pagá-lo.

Sugeri entendimentos com os pais dos alunos e ao próprio proprietário para a solução deste problema, ora criado.

Procurei-o em sua residência e o mesmo não se achava lá. Solicitei, por intermédio da Senhora Professora, que o Sr. Humberto Poloni comparecesse em Atibaia, a fim de, conseguirmos da Prefeitura ou, 
por intermédio dos pais dos alunos e mesmo do Estado, se possível, o pagamento do citado aluguel.

"O proprietário do prédio onde funciona a escola já está ciente da atitude da professora, que o comunicou do seu firme propósito, no caso em apreço."

O ano letivo termina sem a solução do problema, a ata dos resultados dos exames finais, realizados em 27 de novembro, mostra que a escola funcionou normalmente a despeito do problema de instalação, dos 30 alunos matriculados, houve apenas um caso de repetência e nenhum aluno desistente.

No ano seguinte, 1963 o problema continuou:

Nos dias 28/2, 13 e 18/3, visitei o Bairro do Portão, onde havia grave problema com relação ao prédio da escola. O proprietário do referido imóvel, exigia o pagamento de $\mathrm{CR} \$ 2.000,00$ mensais, como aluguel, para entregada chave do prédio. Em companhia do Vigário de Atibaia, amigo do referido proprietário, visitei-o no dia 28/2. A intenção do proprietário era não mais alugar, porém conseguimos demovê-lo do propósito e estipular preço. Ficou assentado que o preço seria de CR $\$ 1.500,00$ mensais, porém, o referido locatário exigia contrato. Esta inspetoria, amparada em texto legal, não poderia permitir que a professora fosse sacrificada, tendo então o $\mathrm{n}$. Prefeito Municipal declarado que pagaria o aluguel. Em 13 de março em companhia do $n$. Prefeito Municipal aqui retornei e o impasse foi resolvido, ficando a Prefeitura Municipal compromissada a pagar 0 aluguel de $\mathrm{CR} \$ 1.500,00$ mensais.

No dia seguinte foi possível então o início das aulas e hoje, 18/3 já encontrei ambas as escolas funcionando regularmente.

Deve-se observar que até então, o governo estadual não se responsabilizava pelo prédio onde funcionava a escola, cabendo aos moradores ou à prefeitura arcar com os custos de aluguel do prédio ficando para o estado manter a professora e os poucos materiais conforme apresentado no Quadro 1. O problema do prédio escolar, havia apenas sido adiado e em 8 de agosto de 1963, na volta às aulas foi registrado que:

"Visitei hoje a E. Ms. Do Bairro do Portão, agora funcionando em outro prédio, distante $1.000 \mathrm{MS}$. do anterior. Não houve possibilidade de continuar naquele prédio que estava melhor localizado, porque o proprietário, alegando necessitá-lo exigiu que fosse desocupado. Graças a compreensão e boa vontade do Sr. Antonio da Cunha Leite, sitiante aqui residente, a escola passou a funcionar num prédio adaptado, localizado no sítio de sua posse.

$O$ referido senhor doou à Prefeitura um terreno defronte a esta escola, comprometendo-se o Sr. Prefeito Municipal a iniciar a construção de 2 salas de aula na próxima semana. 
Por ser $02^{\circ}$.dia de aula e talvez por ser distante $1.000 \mathrm{~ms}$ do anterior, hoje houve muitas faltas. "Dos 32 matriculados compareceram apenas 20 , dando a percentagem de $62,50 \%$ apenas $(\ldots) "$

Este assunto foi esclarecido por uma das entrevistadas Hilda da Cruz Leite, em seu depoimento nos informa que "a primeira escola foi ali, depois dividiu o terreno e o Humberto Poloni não quis mais a escola ali, daí meu pai doou duas casinhas que ele tinha no terreno dele, que era na rua que hoje leva seu nome, Rua Antonio da Cunha Leite, ai que a escola foi para lá e funcionou lá no terreno do meu pai, um tempo grande. Às vezes tinha até escola a noite, tinha meu primo Valdir, tinha vários que estudavam a noite. Eu lembro da professora que ia à noite, chamava Ele Nice Arantes. E a nossa professora desse período todo era a Oceania Oliveira, do meu primeiro ao quarto ano, foi a mesma professora... e ótima viu, muito boa professora."

O livro de registro da escola complementa a lembrança de Hilda, conforme pode-se verificar: "a direção da Escola Mista do Bairro do Portão, encontra-se a professora efetiva D. Oceania Oliveira, com 35 alunos de $2^{\circ}$. E 3․ Graus (19 meninas e 16 meninos)".

A Escola Noturna conforme verificou-se nos registros já existia desde 1951, sendo administrada pelo Grupo Escolar José Alvim, que oferecia os Cursos do Serviço de Educação de Adultos do Município de Atibaia. Em ata da segunda reunião pedagógica de 16 de julho de 1951, o Inspetor Escolar que presidia a reunião assim se manifestava:

O professor não deve desanimar quando notar que o progresso é lento, pois os alunos do primeiro ano são os mais desanimados que os do segundo ano. Só mesmo depois que o aluno começar a aprender alguma coisa é que vai despertando o interesse.

Esse período de desanimo passa logo que o aluno comece a aprender (...) na roça o desanimo é maior, portanto precisa que o professor insista mais. Os alunos tem mais vontade e tem competência para avaliar o que sabe e o que aprendeu.

Quando o professor der um problema para os alunos resolverem dever dar, de acordo com as necessidades dos alunos, um problema direto ao viver deles (cada um).

O programa de geografia e história é o que menos interessa aos alunos, portanto os professores não devem forçar, mas devem dar 0 programa em forma de questionário, de uma forma imperceptível... Os trabalhos de linguagem devem ser feitos em caderno separado, com ordem e capricho; assim os professores irão ministrando os princípios de ordem. 
Os alunos do primeiro ano fazem os exercícios de linguagem a lápis e os do segundo ano fazem a tinta,

Geralmente os alunos do curso de alfabetização de adulto, tem a mão dura e encontram dificuldade em escrever, e interessante então fazer um exercício de caligrafia muscular; pois esses exercícios fazem com que a mão tome o jeito de escrever...

Este documento deixa evidente o tipo de escola que era oferecida aos trabalhadores analfabetos. Explicita a violência simbólica e o controle ideológico ao decretar que na roça o desânimo é maior", "o programa de história e geografia é o que menos interessa", "assim os professores irão ministrando os princípios de ordem" e finalmente, que os adultos, trabalhadores "tem a mão dura". Assim, para os trabalhadores da roça aprender os rudimentos da escrita e algumas operações matemáticas era o suficiente, afastando-os das possibilidades de leitura de mundo e formação crítica da sociedade.

O livro de visitas nos mostra que em 1964, ano do Golpe Militar, a escola foi visitada quatro vezes, em fevereiro, agosto e novembro pelo Inspetor Escolar e em outubro de 1964 recebeu a visita do Delegado de Ensino, o que evidencia um controle maior por parte do estado após o golpe militar de abril. Eis como essas visitas foram registradas:

"Visitada nesta data. Os trabalhos escolares seguem seu ritmo normal. Dos 35 alunos matriculados $(22+13)$ estavam presentes $18+12$; porcentagem $85,7 \%$. O prédio adaptado oferece conforto razoável. “

O "conforto razoável" constatado pelo delegado de ensino é contestado por alguns ex-estudantes entrevistados: "Era uma casinha simples, de taipa, de barro, tinha umas carteiras de madeira. Uma janelinha de madeira, uma portinha bem velha, uma calçadinha de pedra e um degrau para entrar, tinha a lousa".(Aparecido Bizarri).

Naquele ano de 1964, o resultado dos exames finais ficaram muito abaixo dos anos anteriores, dos 35 alunos matriculados e presentes no exame apenas 22 foram promovidos. Não existe relato para justificar o mau desempenho da escola, a professora era a mesma Oceania, e também a examinadora, fica a pergunta: havia começado o controle do estado autoritário? 
Pode-se dizer que nas duas décadas anteriores, a escola rural gozava de uma relativa autonomia, a inspeção se dava apenas no controle das matrículas, frequência e aproveitamento final do alunos. Isso se deve provavelmente ao pouco interesse da administração pelo currículo escolar desenvolvido nas escolas rurais, o que contava realmente era se as escolas tinham o número adequado de alunos e se valia a pena manter a professora e o mobiliário, conforme demonstram os registros.

Nos anos seguintes, o número de alunos aumentou. Em 1965, a escola contava com 40 alunos, 31 do segundo ano e nove do terceiro ano, conforme a ata de visita lavrada em 18 de março de 1965. De maneira contraditória e de difícil compreensão, o Inspetor Escolar muda seu parecer sobre as condições da escola: A sala de aula é pequena e os 40 alunos estão mal acomodados. A
prefeitura municipal planeja construir no corrente ano, um prédio com
quatro salas de aula, prevendo assim para futuro, um grupo escolar,
pois existe no Bairro três escolas superlotadas sendo de se prever
para o próximo ano o mínimo exigido para criação de grupo escolar,
isto é, 160 alunos.

Cabe ressaltar que as três escolas, em verdade eram três salas mistas. Havia também a escola do Bairro da Água Espraiada, em condições precárias e com o agravante de oferecer o ensino somente até o terceiro ano, conforme relato: " $A$ escolinha era uma casinha, tinha uma cozinha, uma sala, não me lembro se tinha quarto porque a gente era molecada (...) Sim, era de tijolo, telha comum né (...) eu fiz primeiro, segundo e terceiro ano, nessa casinha atrás da lgreja da Água Espraiada, que está lá a lgreja até hoje, que é um patrimônio da Água Espraiada esta Igreja. Quando eu terminei o terceiro ano, eu tinha que fazer o quarto ano, aí aqui não tinha... como que tinha que fazer? Está bom, estudar lá no Bairro do Portão, que dá $6 \mathrm{~km}$. Aí eu tive que descer a pé até lá todo dia, cinco e meia da manhã saia de casa andando, pra fazer o quarto ano no bairro do Portão que também era numa casinha, não tinha o prédio que tem hoje, e era uma casinha parecida com a casinha que nós tínhamos aqui".(Benedito Santana)

Em visita feita pelo inspetor em setembro aparece no livro de registro, pela primeira vez referência a um plano de trabalho, "O Plano de Educação Rural", que vinha sendo desenvolvido pela professora. Este plano de trabalho não foi encontrado nos arquivos da escola, mas o que fica mais uma vez em pauta é a 
presença de indícios de maior controle e o início da tecnoburocratização na escola rural, pois o planejamento é uma das estratégias de dominação cultural, uma forma de poder aplicado às escolas, aos seus profissionais e estudantes.

Em 1966 finalmente o estado assume legalmente a existência da Escola, que foi "criada" por Ato de 25, publicado em 26/11/1966, nos termos do Artigo 182 do Decreto 17.698, de 26/11/1947. Foi inaugurado o prédio próprio da escola no mês de março de 1967, construído pela prefeitura do município, em terreno doado por um morador. A partir de então o controle burocrático e as formas de violência simbólica se intensificam.

Em 1971 as escolas isoladas foram transformadas em escolas agrupadas, com cinco classes comuns e não mais multisseriadas e um diretor, responsável pela administração da escola. O livro de atas das reuniões pedagógicas mostram, a partir de então, que o controle sobre os professores e os alunos tornava-se mais intenso. O currículo escolar passa a ter aulas de religião católica e de civismo, fato narrado também pelos entrevistados: "E o Walter Barca era um professor muito severo, a gente marchava todos os sábados na frente da escola e cantava o hino nacional." (Benedito Santana). "Mas o diretor da escola, Seu Josias era um verdadeiro carrasco. Também a Dona Luci era muito autoritária, não podíamos fazer nada (...) Era a época da ditadura e a gente tinha que fazer um chapeuzinho de papel, pôr na cabeça e marchar em frente e ao redor da escola”. (Josué Cosme Fernandes).

Em 1976 foi construído um novo prédio, e no ano seguinte a escola recebeu nova denominação, através da Resolução SE 131/77, foi transformada em Escola Estadual de Primeiro Grau do Bairro do Portão e passou a atender alunos a partir da quinta série, o prédio anterior (prédio velho) continuou com as classes de primeira até a quarta série.

Conforme relato dos ex-estudantes, a continuidade do ensino de primeiro grau acontecia até então apenas em uma escola urbana: “É, quando mudou o prédio...Demorou para mudar viu, porque daí eu já não estudava mais lá. Eu já estudava no Ginásio Major, do estado, eu ia para Atibaia. Tinha na época a admissão né. A gente estudava muito mais, daí 4 anos de ginásio e 3 de segundo grau né. A gente ia de ônibus de linha, quando estava muito lotado a gente corria o risco de não chegar na escola."(Hilda Cruz Leite) 
Outra alternativa era a escola privada: "O colégio era particular (...) e eu pagava 56 cruzeiros pra escola e mais o ônibus para ir. Instituto Educacional Gertrudes Pires Alvim que era do professor João Pereira Dias, o prof. João! Eu lembro até hoje daquela época, lembro dele, lembro da mulher dele que trabalhava na secretaria, e aí eu fiz até metade da oitava série, aí por motivo de trocar de emprego eu saí e parei de estudar. Eu fiquei parado até hoje, e não sou formado em nada". (Benedito Santana).

Por meio da Lei 1.591/78 a escola passa a ser denominada EEPG Profa. Zilah Barreto Pacitti, atendia alunos até a $8^{a}$. Série e administrava quatro escolas isoladas, instaladas em bairros rurais vizinhos, a escola do Bairro da Água Espraiada, a Escola Isolada da Fazenda Palmeiras, a Escola Isolada do Bairro da Lagoa e Escola Isolada do Bairro dos Pintos.

Outro fato marcante na história da escola aconteceu já no final dos anos de 1980, quando a população passou a reivindicar a instalação do Ensino de Segundo Grau, o que ocorreu em 1992, após intensa mobilização da população do bairro do Portão. A instalação do então ensino de $2^{\circ}$. Grau constituiu um paradoxo pois naquele momento a ordem que vinha "de cima"era fechar as escolas rurais e transferir os estudantes para escolas urbanas, política que se intensificou ao longo da década de 1990 com o processo de municipalização no Estado de São Paulo.

\subsection{As trajetórias dos ex-estudantes das escolas rurais do Bairro da Água Espraiada e do Bairro do Portão.}

Neste momento, pretende-se captar e analisar as memórias dos exestudantes sobre a escola, focalizando em suas narrativas o processo de escolarização tanto no que diz respeito ao ensino-aprendizagem, como também suas percepções sobre as condições da escola, os professores, os colegas e os conteúdos mais significativos que marcaram suas experiências escolares.

Foi levado em consideração, conforme recomenda Portelli (1991), o contexto em que aconteceram as entrevistas, porque esse pode influenciar o processo de criação de fontes por meio da coleta de depoimentos. Segundo o autor, no momento da "entre-vista" ocorrem trocas e visões mútuas, onde entrevistado e entrevistador 
agem juntos, se reconhecem entre si como sujeitos e tentam construir essa igualdade sobre suas diferenças, trabalhando juntos.

Fazendo uma leitura geral das entrevistas, optou-se por num primeiro momento, apresentar por meio de um texto editado uma breve biografia dos entrevistados e o contexto em que aconteceram as entrevistas.

\section{Quadro 2. Ex-alunos entrevistados.}

\begin{tabular}{|l|c|l|l|l|}
\hline Nome & Nascimento & Local & Ingresso & Profissão atual \\
\hline Aparecido Bizarri & 1953 & Atibaia & 1960 & Construtor \\
\hline Benedito Santana & 1954 & Atibaia & 1961 & Comerciante \\
\hline Hilda da Cruz Leite & $\begin{array}{c}\text { Não } \\
\text { Informado }\end{array}$ & Atibaia & Aos 7 anos & $\begin{array}{l}\text { Administradora } \\
\text { de Empresas }\end{array}$ \\
\hline Luiza Santana & 1960 & Atibaia & 1967 & Balconista \\
\hline Sueli Fátima Rodrigues & 1960 & Guarulhos & 1968 & Nutricionista \\
\hline Sueli Matuoka & 1965 & Atibaia & 1973 & Comerciante \\
\hline Josué Cosme Fernandes & 1967 & $\begin{array}{l}\text { Natércia- } \\
\text { MG }\end{array}$ & 1981 & $\begin{array}{l}\text { Gestor público } \\
\text { (RH). }\end{array}$ \\
\hline Aucinete Oliveira Costa & 1977 & $\begin{array}{l}\text { Limoeiro do } \\
\text { Norte-CE. }\end{array}$ & 1984 & Balconista \\
\hline
\end{tabular}

Fonte: Entrevistas, organizado pela autora.

As entrevistas feitas com Luiza e Sueli Matuoka, foram realizadas no local de trabalho. Sueli Matuoka é descendente de japoneses e tem um comércio que funciona na propriedade da família, que anteriormente ocupava-se com o cultivo da terra. No que restou do patrimônio herdado foi instalada uma pequena empresa familiar, uma parte do comércio destina-se à venda de produtos agropecuários, mudas de hortaliças, árvores frutíferas, plantas ornamentais e todo tipo de equipamentos para sítios e chácaras, além de produtos para cuidados com animais domésticos, que podem variar desde gado bovino, equinos até cães e gatos.

A outra parte do comércio oferece utensílios domésticos, presentes e banca de jornal. Sueli Matuoka é casada com um descendente de japoneses, sua empresa agregou a família do marido e parentes com formação técnica em agropecuária, estes dão assistência em sítios e chácaras da região. O casal tem três filhos, o mais velho estuda engenharia na USP, a filha formou-se na FATEC São Paulo e 
atualmente faz estágio nos EUA. O caçula faz cursinho pré-vestibular em São Paulo. Sueli Matuoka tem 50 anos.

Luiza é casada, tem duas filhas e uma neta que vive com ela. Trabalha como balconista no comércio de Sueli Matuoka, seu marido é tapeceiro, as filhas terminaram o ensino médio e trabalham no comércio no centro de Atibaia. Luiza queria que as filhas fizessem uma faculdade, porque ela mesma não teve condições de fazer, conseguiu terminar o ensino médio, graças ao esforço que fez para frequentar o tele curso na escola do bairro, fato de que se orgulha e tem saudades, principalmente das amizades que fez. Além do trabalho fora, Luiza faz todo o trabalho da casa e ainda ajuda uma das filhas a cuidar da neta. Se fosse mais nova e tivesse tempo gostaria de voltar aos estudos.

A entrevista com Sueli Rodrigues aconteceu no salão do restaurante onde é proprietária, em uma tarde tranqüila quando o trabalho havia encerrado. Sueli Rodrigues nasceu em Guarulhos e veio para o Bairro do Portão com oito anos, frequentou a escola do bairro, trabalha desde os oito anos de idade. Estudou até o quarto ano, depois foi trabalhar como empregada doméstica e mais tarde em uma empresa de processamento de legumes e frutas localizada num bairro da periferia da cidade. Casou-se com um rapaz do bairro, que não deixou que ela continuasse os estudos, teve quatro filhas. Voltou a estudar na escola do bairro aos 48 anos, idade em que conforme nos contou foi a idade da libertação, havia perdido o medo. Fez o curso supletivo para terminar o primeiro e o segundo grau. Mais tarde fez um cursinho pré-vestibular comunitário e entrou para o curso de Nutrição em Bragança Paulista. Na época da entrevista era proprietária de um dos melhores restaurantes do município de Atibaia, frequentado por funcionários graduados e por turistas nos finais de semana. Orgulha-se da sua trajetória, de menina pobre, que passou até fome e que conseguiu criar as filhas, formá-las e cursar a faculdade de nutrição e ser dona do próprio negócio. Mas quer vender o restaurante, mudar de vida e ser feliz.

Hilda foi entrevistada na sua sala de trabalho, é um ambiente bem tranqüilo e aconchegante. Hilda contou que é solteira, nasceu no Bairro do Portão, é descendente de italianos e brasileiros de Atibaia. A mãe de Hilda pertence à família tradicional do bairro e o pai era filho de brasileiro casado com italiana. Hilda atualmente trabalha como administradora em uma empresa que fabrica tapetes 
arraiolos no Bairro do Portão. Os tapetes são comercializados na loja existente no próprio bairro, fundamentalmente para turistas. Parte da produção é exportada.

Hilda não revelou a idade, atualmente mora na cidade de Atibaia. Estudou na escola do bairro, quando ainda funcionava no sítio da avó, a escola viria depois a funcionar no próprio sítio do pai, onde moravam. Quando inaugurou o prédio próprio das escolas agrupadas já estava estudando na cidade, fez o curso de admissão e fez o curso ginasial na Escola Major e depois o curso de magistério em uma escola particular.

Ao mesmo tempo em que fazia a segunda etapa do primeiro grau, fez o curso de corte e costura e modista na cidade, com a mãe da TizucaYamasaki (cineasta famosa). Trabalhou muito tempo como costureira e modista, mais tarde com o crescimento da escola do bairro, e ser uma das únicas com formação adequada foi trabalhar na secretaria da escola e também como professora substituta.

Hilda é muito reservada, pensa para falar, mesmo assim deu uma longa entrevista, com muitos dados importantes para entender a evolução da educação escolar no bairro e o cotidiano das crianças e jovens. Neta de avó italiana e avô brasileiro tinha uma condição de vida melhor em relação às demais crianças. Os pais eram alfabetizados, a mãe ocupava-se com as tarefas domésticas, mas sempre tinha alguém para ajudar a cuidar da casa e das crianças, que eram muitas. $O$ pai tocava o sítio juntamente com parceiros e era comerciante.

Aucinete tem 38 anos, nasceu em Limoeiro do Norte,- CE, veio para o Bairro do Portão com dez anos, estudou até a 3ª. Série em Limoeiro do Norte e depois na Escola do Bairro do Portão, até terminar o Ensino Médio. O pai trabalhava em São Paulo, na construção civil e mandava dinheiro para a família que ficou no Ceará, anos depois ele foi buscar a família e chegaram no Bairro, onde Aucinete reside até hoje. Contou que na cidade onde nasceu, não havia trabalho para o pai, carpinteiro e marceneiro e que ele veio para São Paulo com um tio que o trouxe para o Bairro do Portão para trabalhar na sua profissão. Esse tio trouxe praticamente a família toda para o bairro, cerca de 60 pessoas, todos os adultos, homens e mulheres conseguiram trabalho e até hoje residem bairro, em um lugar que é conhecido como Vila Ceará. Os pais decidiram voltar para o estado do Ceará. Aucinete está casada e tem dois filhos. Trabalha como balconista na padaria do Bairro, quer voltar a estudar 
assim que a filha caçula crescer mais um pouquinho. A entrevista foi feita em sua casa, após a chegada do trabalho.

Benedito Santana, 62 anos, nasceu no Bairro da Água Espraiada, onde reside até hoje. Atualmente trabalha como lenheiro, planta, cultiva e colhe eucaliptos que comercializa em pizzarias de São Paulo e Santos. É muito falante e bem humorado. A entrevista foi feita na casa dele, foi a mais longa e cheia de detalhes,era um domingo e ele nos recebeu para um almoço. Enquanto o almoço era preparado, nos sentamos à mesa da cozinha para a entrevista.Dito da Venda como é conhecido, estudou no bairro da Água Espraiada até a terceira série, depois para fazer a quarta série ia a pé para o Bairro do Portão.

Benedito conta que sempre foi um dos melhores alunos da classe, embora tivesse começado a trabalhar aos 8 ou 9 anos, ajudando o pai na roça. Quando terminou a quarta série foi trabalhar como empregado em um alambique do Bairro do Portão, queria prosseguir os estudos e a família não tinha como custear. Voltou a estudar com 15 anos, em uma escola particular que ele mesmo pagava, estudava à noite e trabalhava o dia todo. Não conseguiu estudar além da 7ạ. Série. Foi trabalhar em um armazém e depois tornou-se proprietário do estabelecimento. Seu pequeno negócio faliu com a chegada dos supermercados, a partir de então trabalha com lenha. Disse-me assim: Sou feliz, mas poderia ser um contador ou advogado, tinha inteligência para isso.

A entrevista com Bizarri foi realizada em minha casa, conforme ele solicitou por achar mais apropriado. Aparecido Bizarri tem 63 anos, nasceu no bairro do Portão, o pai era descendente de italianos e a mãe é brasileira. Tem um escritório de construção civil, com telefone secretária e um funcionário. É construtor, estudou na escola do Bairro até a quarta série. É autodidata, começou trabalhando na roça com o pai, mais tarde com a decadência do setor agrícola, foi trabalhar como servente de pedreiro e aprendeu a profissão. Atualmente trabalha em grandes construções, principalmente com arquitetura à base de pedras. Construiu mansões em praias do litoral, em fazendas e edifícios em São Paulo. Recebeu há alguns anos uma Comenda do Ministério da Cultura, pelo trabalho realizado na preservação da arquitetura tradicional caipira. Foi casado, teve quatro filhas, todas fizeram o curso superior. Disse que o estudo fez muita falta, porque não pode assinar plantas das construções que faz, e muito engenheiro formado não sabe o que ele sabe. Gostaria de ser arquiteto. 
Josué tem 42 anos, é mineiro de Natércia, cidadezinha do sul de Minas Gerais com 3.500 habitantes, chegou no Bairro do Portão aos três anos de idade, em 1970. O pai veio para trabalhar na construção civil. Entrou na escola com sete anos de idade e estudou na Escola do Bairro até o terceiro ano do Ensino Médio. Começou a trabalhar com dez anos, como catador de bolinhas de tênis em um Clube de Campo. Adorava a escola, mais que do estudar até... Repetiu a sétima série, participou do Grêmio Estudantil e do Movimento da Juventude Católica no bairro, lidera até hoje um Grupo de Teatro - O Teatro do Portão, antes o Grupo chamava-se Sal da Terra, depois como jovens de outras religiões queriam participar mudaram o nome para Teatro do Portão, formado por atores premiados, do próprio bairro.A escola foi muito importante para a socialização, foi nela que aprendeu sobre política, é filiado ao PC do B, prestou concurso e é servidor público municipal, com incentivo da chefia na prefeitura, fez faculdade de Gestão Pública, é casado com uma colega do tempo da escola, tem um filho. A entrevista foi feita na casa de Josué e sua mulher, que nos recebeu para fazer a entrevista. Esta foi realizada com tranqüilidade e muita disposição por parte do entrevistado em relatar os acontecimentos que marcaram sua trajetória de vida.

\subsection{Análise do conjunto das entrevistas em diálogo com a bibliografia especializada.}

A escolarização é um acontecimento coletivo e, ao mesmo tempo, uma experiência individual. Não se podem compreender as pessoas dissociadas da sociedade, da cultura e da educação, construídas historicamente por elas próprias. As singularidades das pessoas são expressões da historicidade e encontram-se imbricadas na complexidade das relações sociais. Dentre essas, as relações que se estabelecem na escola são partes importantes e atuam na constituição das identidades, conforme se pode verificar nos relatos das pessoas que foram entrevistadas e que constituem a parte empírica desta pesquisa.

Os relatos colhidos durante a pesquisa de campo constituem em sua totalidade fontes importantes para o conhecimento do modo de vida das pessoas que viveram em um tempo de profundas transformações econômicas, sociais, 
políticas e na forma de acesso às informações e à produção do conhecimento na era da informática.

Pode-se verificar que as mudanças e permanências que ocorreram em um tempo relativamente breve em todos os setores da vida provocaram marcas na identidade de cada um dos entrevistados. Fazer uma análise que abrangesse a totalidade das informações colhidas ultrapassaria os limites propostos neste trabalho. Assim, ateve-se às questões que, de forma recorrente, perpassam todos os relatos. Estas foram agrupadas em temas, pois interessa aqui mais o conteúdo sociológico dos depoimentos, já que o interesse é conhecer a infância, a trajetória escolar, a importância da escola e se esta correspondeu ou não às expectativas do grupo social em pauta. Os temas ora tratados são Infância e trabalho; Gênero e escolarização; Violência e percurso escolar. Tais temas serão tratados, como já foi dito, tendo por referência os conceitos de violência simbólica, habitus e trajetória.

Desde Hegel o trabalho é considerado uma categoria de análise capaz de explicar a relação do ser humano com a natureza e como elemento mediador para formação da consciência. Nas entrevistas realizadas, essa categoria permitiu verificar se houve diferenças e semelhanças na significação do trabalho para os entrevistados, lembrando que todos são oriundos do mesmo grupo social, ou seja, famílias autóctones que tinham a posse da terra e dela tiravam o sustento, e famílias de migrantes, que chegaram ao bairro após os anos 70. Essa questão é importante porque há uma tendência, conforme apontou Queiroz (1991,p.141), de tratar essa camada da população como um todo homogêneo, como se no seu interior as diferenciações fossem superadas ou mesmo apagadas pelo determinante econômico.

O trabalho aparece nas memórias como um tempo roubado do estudo. Os relatos mostram que as pessoas têm nostalgia do período que frequentaram a escola e pesar por ter que deixá-lo para trabalhar. Luiza, uma das entrevistadas, afirma: "estudei só até a quarta série, tinha onze anos e fui trabalhar como empregada doméstica (...) meus pais também já trabalhavam como assalariados no Clube da Montanha (...) antes trabalhavam na roça... plantavam e vendiam... depois continuaram a morar no sítio, mas saiam para trabalhar com salário fixo (...) e eu não tive mais condições de estudar. Por meio dessa fala, é possível identificar as transformações no mundo do trabalho que levaram a família ao assalariamento, 
interrompendo a escolarização das crianças, o que pode ser considerado uma das faces da violência do modelo capitalista de produção.

Nem mesmo o sucesso escolar era garantia de continuidade da escolarização. Na fala de Benedito Santana, podemos observar essa afirmativa: "nunca repeti de ano, sempre fui o primeiro da classe. Desde o primeiro ano eu não trabalhei... quando eu estava no primeiro, segundo e terceiro ano... não trabalhei não... só depois do quarto ano em diante que eu trabalhei...eu estava com onze anos... eu molhava as plantas e cuidava das galinhas, no sítio do vizinho... que estava montando um sítio, meu pai trabalhava desmatando... ele não tinha mais condições de plantar para sobreviver da nossa terra... era 1968 e ele ganhava Cr\$5,00 (cinco cruzeiros) por semana e eu ganhava a metade...depois fui trabalhar no depósito de material de construção do Josevino Mendes ... todos meus irmãos foram só até o terceiro ano na Escola... o Mingo nem o terceiro ano fez... eles cuidavam da roça de casa... quem fez até o quarto ano fui eu, a Regina e o Jorge, só os mais novos... Eu tentei fazer a quinta, sexta ... mas trabalhando para pagar...com 16 anos... trabalhando e pagando... fiz até a sétima série." (Benedito, 62 anos).

Do mesmo modo, Sueli Rodrigues nos contou: "eu já estava na escola... meu tio foi nos buscar porque estávamos em uma situação muito ruim... Passando fome mesmo... Meu pai foi preso... até hoje não sei o motivo... Mudamos e comecei novamente a primeira série no Bairro do Portão... Fomos morar na casa de um tio... e eu e meus irmãos fomos trabalhar, todos... Fazer alguma coisa para ajudar... Acordávamos de madrugada, às duas da manhã... Depois a gente ia para a escola... e voltava para continuar empilhando tijolos... Além da olaria ajudávamos também no trabalho da roça, meus tios tinham um sítio e plantavam milho, mandioca, amendoim, feijão que era pro gasto e para vender. Aqui a violência expressa-se na perda do direito à infância, mostrando uma das faces da violência em uma grande cidade, como Guarulhos.

O fator de diferenciação entre os ex-estudantes revela que a escola por si só não foi capaz de homogeneizar as condições de vida dos estudantes. Um relato pertinente é o de Hilda, que apesar de ter condição de vida melhor que dos outros entrevistados, também tinha relação com o mundo do trabalho: "eu trabalhava... enquanto fazia o ginásio... minha mãe me colocou no curso de corte e costura, com 
12 anos... com 13 anos eu era excelente estilista... fiz roupa para muita gente, eu fazia até paletó de homem.".

Os fatos narrados tornam-se mais compreensíveis à luz do conceito de habitus, pois os ex-estudantes, como já afirmado anteriormente, tendo as mesmas condições de vida, embora com pequenas variações, incorporaram as mesmas disposições que, ao se interiorizarem, transformam-se em verdadeiros traços de personalidade, ou seja, em uma segunda natureza, profunda e durável, passaram da condição de crianças que trabalham e estudam, para a condição de adultos trabalhadores que ainda trazem as marcas do seu passado de estudante.

Se for analisado do ponto de vista da violência simbólica, o trabalho para as crianças era considerado natural, só que estava muito longe de ser o tradicional aprendizado que se dava no seio da família camponesa e caipira. $O$ trabalho adquire um caráter obrigatório à medida que as famílias são expropriadas dos meios de produção, especialmente a terra. Verificam-se nos relatos que não se trata de uma simples ajuda nas tarefas, mas sim uma importante fonte de renda familiar. Todos trabalhavam com remuneração, evidenciando a desarticulação do antigo trabalho familiar e também do mundo rural.

Assim, por meio do trabalho compulsório, as crianças são integradas à massa de trabalhadores juntamente com suas famílias que, subordinadas ao trabalho de modo formal, passam da condição de produtoras à condição de consumidoras. Desse ponto de vista, o trabalho é uma categoria que age como fator de homogeneização.

No entanto, um olhar mais acurado permite a identificação de outra categoria, a de gênero, que funciona como fator de diferenciação no grupo, na medida em que vão se delimitando as ocupações consideradas mais femininas e outras masculinas, como se pode perceber nas trajetórias de vida. Meninas são encaminhadas para o serviço doméstico ou corte e costura, enquanto que os meninos são encaminhados para os trabalhos fora de casa, com ocupações no comércio, na construção civil ou na lavoura como assalariados. Mesmo as que tiveram momentos de ruptura e conseguiram cursar o nível superior, o fazem na tendência dominante, tornando-se profissionais da educação, nutricionista ou empregadas subalternas no comércio. Assim, ao mesmo tempo em que o trabalho homogeneíza as pessoas como pertencentes a uma classe - a classe trabalhadora, submetida aos ditames da 
produção e do mercado - ele também diferencia e hierarquiza o grupo social internamente, sem, contudo, mudar a sua condição de classe.

Nesta análise buscou-se também verificar, por meio dos relatos, como a escola operou enquanto agência formadora. A violência, também no processo de escolarização, apresenta-se força dupla: explícita, a cujos exemplos não poderíamos nos furtar neste texto; e simbólica, que ocorre de maneira mais sutil, mas também colaborando de forma efetiva na constituição do habitus e marcando a trajetória de vida dos entrevistados.

A violência explícita é assim narrada por Sueli Rodrigues, ao falar de seu irmão e colega de escola: "Ele era terrível...o professor o castigava muito... No geral as professoras eram boas, punham de castigo e batiam com a régua na mão somente das crianças que não eram comportadas". Sueli arranja uma forma de desculpar o professor pelas agressões e também relata um momento de violência simbólica: "A professora era muito boa...nossa... a que mais marcou foi a Prof. Perfeita, me ensinou muito...principalmente nas questões do comportamento, higiene, tomar banho, cortar as unhas".

Aparecido Bizarri também tem um relato triste de violência explícita: " $A$ professora era a Dona Rosalina, mas tinha a dona Oceania também, eu lembro até uma vez que aconteceu de eu bocejar, e eu tinha mania de bocejar sem colocar a mão na boca. E umas três vezes ela repreendeu ... então um dia eu bocejei e ela estava lá, olhando, e veio com uma reguona de madeira e deu uma reguada na minha cabeça... chegou até a quebrar a régua. E ela disse: nunca mais você abre a boca sem por a mão na boca! Ponha a mão na boca! Então, eu pus a mão direita na boca e ela deu mais uma reguada com o pedaço que tinha sobrado da régua e gritou: Não é a direita! É a esquerda! Porque com a direita você cumprimenta os outros... Ela era muito rígida e implicava muito com a higiene das crianças...".

Em que pese a violência simbólica ou explícita praticada por alguns professores no processo de escolarização das crianças das escolas rurais, a aprendizagem acontecia de forma satisfatória. Não foi encontrado nos documentos pesquisados casos extremos de desistência da escola ou de repetência durante o período estudado, como demonstram também os relatos dos ex-estudantes. "Não faltava nenhum dia. Coisa incrível viu, acho que naquela época as professoras amavam o que faziam, porque não faltavam. Era assim, a gente vinha de muito 
longe, da casa da minha mãe até na casa da minha avó onde era a escola, e era mata fechada, e era a estrada onde passava a boiada, então a gente vinha." (Hilda).

Isso evidencia que a despeito de a escola não contar, durante um grande período com instalações adequadas e apresentar deficiências materiais de toda ordem, esses fatores não eram determinantes para o fracasso escolar na zona rural estudada. Na visão dos ex-estudantes, a escola era um lugar agradável onde podiam brincar e aprender: "A escola era boa, a sala de aula limpa, tinha só a lousa, a mesa da professora e as carteiras" (Sueli Rodrigues); "Era uma casinha simples, de taipa e barro, mas todo mundo aprendia, tabuada, ler e escrever. Aprendi muito bem, a gente tinha um caderno, uma régua, um lápis e uma borracha que o pai comprava. Não tinha livro, a professora passava a lição na lousa, a gente copiava e aprendia." (Aparecido Bizarri); "Imagina um menino andar $6 \mathrm{~km}$ pra ir na escola para fazer o quarto ano. Aí a gente chegava de manhã, chegava lá 6 horas na manhã, levantava de manhã, de madrugada, descia morro abaixo, chegava lá encontrava os meus amigos de escola. E, a gente ia pra escola, na casinha, lá era o Walter Barca o nosso professor. Aí a gente ficou o começo do ano, um, dois, três meses e em maio o Walter Barca falou, a gente vai mudar em maio para a nova sala de aula do Portão, que eram as primeiras quatro salas que fizeram lá com o terreno que o Humberto Poloni doou, para fazer as salas de aula. Fizeram quatro salas de aula lá, maravilhosas, com gramado em volta."(Benedito Santana).

Todos os relatos confirmam a importância que a escola e o processo de escolarização tiveram em suas trajetórias de vida. Relatam como foi importante o aprendizado e sobretudo, as relações sociais que se estabeleceram por meio da escola: "A escola foi muito importante para a socialização... tivemos uma excelente formação... se não fosse a escola a gente não teria consciência de podermos participar da vida política... meu irmão mesmo foi vereador... também aluno da escola...eu sou filiado ao PCdoB... Prestei concurso para a prefeitura e hoje sou funcionário... lá também tive incentivo do meu chefe, a quem eu devo minha formação na faculdade, ele conseguiu uma bolsa de estudos e pude me formar em Gestão Pública." (Josué). Eu diria que sem a escola, eu não teria conseguido fazer tudo o que fiz, sou muito grata a escola. (Hilda).

Outros aspectos do funcionamento da escola podem ser compreendidos por meio dos relatos, temas como alimentação das crianças, acesso aos materiais 
escolares e as relações entre colegas de escola são importantes para a apreensão da política educacional planejada para o ensino rural.

Nos depoimentos pode-se constatar as dificuldades das famílias em manterem as crianças na escola, sobretudo quando avançavam em seus estudos. "Quando entrei no ginásio, na cidade, eu tinha uns 12 ou 13 anos...eu lembro de ir de uniforme, de meia branca...tinha muito barro na estrada...por isso eu me lembro da meia branca, sapato tipo boneca, e o uniforme... blusa branca e saia cinza... a escola era muito exigente... quando eu comecei ...Material tinha que comprar tudo... muitos livros... depois fui fazer o magistério e era pago. (Hilda).

Durante o período escolar, a alimentação das crianças era um grande problema para as famílias. Os estudantes acordavam muito cedo para irem a escola e nem sempre havia alimentos que pudessem ser levados e comidos mais tarde, porque praticamente só havia alimentos in-natura. Os estudantes que moravam próximos à escola iam para casa tomar as refeições, como nos contou Hilda: $A$ minha avó Tereza não cobrava nada... ela mandava almoço para as professoras...eu me lembro, a gente ia rapidinho em casa, comia e voltava... quem estivesse junto também comia na casa... merenda na escola?... nem pensar.

Luíza também nos contou que levava marmita mesmo, às vezes bolinho de arroz... uma delícia... com muito cheiro verde. A professora comia sempre alguma coisa... fazia cróc cróc... eu não sabia o que era...mas nunca esqueço do cróc-cróc...

A narrativa de Benedito Santana foi essencial para verificarmos a ausência quase total de produtos industrializados para a alimentação: A escola não tinha nada de alimentação...a gente levava de casa... se não tivesse para levar ficava sem nada. Eu andava seis quilômetros para chegar a escola, levantava cedo, chegava na escola às seis ou sete horas da manhã, a aula começava às oito...descia morro abaixo, encontrava os amigos e ia numa chácara , quem cuidava da chácara era a Dica, irmã do Eli que estudava comigo...a gente ia chupar mexerica e depois ia para a escola... Quando mudamos para o prédio novo, o Walter Barca, que era o professor falou assim: a gente vai arrecadar dinheiro para comprar um liquidificador, porque a prefeitura mandou farinha de aveia e leite em pó, o liquidificador era para bater... eu lembro que depois ele punha groselha e a gente tomava leite com aveia, sabor groselha... Mas a minha mãe fazia um bolo... esse eu tenho vontade de comer 
até hoje... a minha mãe falava que era o Bolo da Nhá Zefa, comadre da minha mãe...Era um mexido de farinha de trigo, com óleo, sal e fermento, colocava na frigideira e assava, de um lado e de outro...ficava um bolão meio duro... mas era gostoso. Tem um episódio que eu não esqueço até hoje: meu amigo Wladimir, o pai tinha mais dinheiro que o meu...ele levava um lanche de mortadela, naquele tempo era novidade prá mim...o Wladimir... com o lanchão de mortadela na mão falava: Ô Dito, vamos trocar? E eu com o bolo Nhá Zefa no bornal... eu falava - Vamos sim.... para o Wladimir a novidade era o bolo que minha mãe fazia.

Como observado nos depoimentos, não se tratava de passar fome como acreditaram, e ainda acreditam alguns professores, que julgam que a criança pobre vai à escola somente para comer. Diferente das periferias em que o acesso à alimentação é ainda realmente muito restrito, nos sítios havia muita fartura: $E$ no sítio do meu pai tinha muita fartura - tinha de tudo não é? Verduras de todo tipo, mandioca, batata, ervilha, inhame, mexerica, laranja lima, jabuticaba, manga, goiaba, mamão, abóbora, figo para fazer doce, milho verde para fazer pamonha, bolo, curau ou simplesmente comer cozido ou assado...também todo mundo tinha porcos, galinhas, não faltavam ovos... e tinha o costume que quando um vizinho matava o capado (porco castrado para engorda) dava um pouco de carne e toucinho para o outro... sempre trocavam e assim todo mundo tinha carne fresca sempre.(Hilda).

A questão da alimentação escolar foi aos poucos se transformando em rubrica obrigatória nos orçamentos dos governos que a implantaram como política pública. A experiência nas escolas públicas rurais mostrou que existia muita rejeição por parte dos estudantes em consumir a merenda industrializada, enviada pelos governos. Existe uma vasta legislação específica que regulamenta e legitima esse processo, tanto em nível estadual como federal. Não é o caso de tratarmos esse tema de forma minuciosa, pois o que se quer demonstrar é que a cultura alimentar da população rural sempre foi muito rica e diversa, tendo influenciado o processo de implantação da merenda escolar, conforme nos relatou Sueli Matuoka: tenho pouca lembrança sobre a merenda na escola... geralmente era uma sopa de legumes, com macarrão e as crianças contribuíam levando os legumes, temperos e verduras que tinham em suas casas...todo mundo tinha uma horta. 
Existe muito preconceito e discriminação em torno da questão da cultura da população do campo de maneira geral e também nos costumes alimentares. Basta lembrar o preconceito sobre "os bóias frias", "marmiteiros", "gafanhotos" e tantos outros codinomes usados pela população urbana para designar os trabalhadores que costumam levar a comida feita em casa para comer na roça. Em suma, existe uma ideologia (que desumaniza) ao desqualificar a alimentação do caipira e que por meio de intensa propaganda estimula o consumo de produtos industrializados.

A questão da cultura alimentar, narrada pelos estudantes, parece ser um tema que unifica o universo rural, conforme vimos nas narrativas. As memórias deixaram evidentes as preferências alimentares do grupo em estudo existindo até mesmo um saudosismo saudável a esse respeito e que remete às questões mais amplas que envolvem a destruição da cultura, a perda da terra e o avanço do sistema capitalista industrial.

Para tratarmos desse tema recorremos mais uma vez aos estudos de Whitaker (2006), em que são apontados pontos importantes para a compreensão da cultura das populações rurais e a sintonia existente entre o conceito de cultura e o conceito de ecossistema. Para a autora, cultura é tudo o que nos humaniza, homens e mulheres, quando nascem, constituem apenas potências e possibilidades, precisando portanto da cultura para se tornar humanos, e para continuarem humanos. As culturas se desarticulam quando atingidas por impactos tecnológicos estranhos que podem ser catastróficos, colocando em risco a própria existência do grupo, a médio e longo prazo, dependendo das circunstâncias históricas.

A cultura é compreendida pela autora, como um complexo estruturado, formado não só de técnicas e práticas materiais, como também de valores, normas de conduta, juízos, leis, moral, artes e, principalmente, padrões de comportamento, tudo compondo uma trama de símbolos que dá significado às ações dos seres humanos que vivem essa cultura (WHITAKER, 2006, p.65).

A autora, para conceituar ecossistema, toma como referência uma das definições do Glossário de Ecologia da Academia de Ciências do Estado de São Paulo: "é um conjunto de fatores físicos, ecológicos e bióticos que caracterizam um determinado lugar, entendendo-se por um determinado espaço de dimensões variáveis. É em suma, uma totalidade integrada e sistêmica" (...). 
Essa definição aponta as semelhanças entre 0 sistema cultural e 0 ecossistema. A cultura é um complexo estruturado de ações e relações sociais e o ecossistema é uma totalidade integrada por processos metabólicos. Enquanto na cultura elaboram-se práticas e constroem-se padrões sociais que garantem o equilíbrio dinâmico da sociedade, no ecossistema interagem e coexistem uma base inorgânica e uma base orgânica constituída por organismos vivos, o que garante a sobrevivência e a resistência contra os fatores de entropia que ameaçam o equilíbrio do meio ambiente.

Enfim, cultura e ecossistema são processos de alta complexidade, sobre os quais raramente pensa o homem civilizado, habitante da cidade, vive apartado da natureza em um sistema artificial que destrói a diversidade tanto no plano da cultura, como no plano da natureza. (WHITAKER, 2006,p.66).

Em termos de alimentação humana, tema que está se tratando, o problema é cada vez mais grave. Além da perda da terra, estamos presenciando o desaparecimento de milhares de grãos, como o milho, feijão, arroz e tantos outros que constituem há séculos a base da alimentação de todos os povos. 0 empobrecimento da alimentação, sobretudo nas escolas, local onde convivem milhares de crianças e jovens é uma das faces mais cruéis da violência contra a cultura.

As narrativas dos entrevistados forneceriam uma infinidade de temas que contribuiriam, ainda mais, para as reflexões acerca da educação e também de outros campos da cultura. No entanto é necessário um ponto final, o que fica desta análise é a pertinência do recurso da memória social para a compreensão dos fenômenos sociais, como a escolarização das crianças e jovens rurais. 


\section{CONSIDERAÇÕES FINAIS.}

Iniciou-se esse estudo com o propósito de compreender as experiências e a construção do conhecimento nas e sobre as escolas rurais, atentando para as diferenças entre história oficial e memória social. O desafio foi empreendido por meio de uma pesquisa bibliográfica, somada a uma pesquisa empírica, conduzida por meio do método da história oral, a fim de dar voz aos sujeitos cuja escolarização deu-se no seio da escola rural.

O período que foi estudado foi pródigo em reformas e leis educacionais. No que diz respeito a Lei 5692/71, Lei de Diretrizes e Bases vigente durante o período da ditadura militar, esta serviu somente para o controle do processo de escolarização. Esse controle, sobretudo ideológico, como foi visto no capítulo dois, deixou marcas profundas na educação brasileira, na medida em que não só não cumpriu aquilo que tinha de mais interessante - a terminalidade do primeiro grau, por meio do qual os brasileiros passaram a ter direito a oito anos de escolarização como também desestruturou o ensino de segundo grau e impulsionou a privatização dos níveis mais elevados de ensino.

Dos documentos consultados no acervo da escola, nenhum faz referência às mudanças, na prática, decorrentes da Lei 5692/71, o que causa estranheza, uma vez que esta legislação estava em vigor, trazendo transformações estruturais no funcionamento das escolas públicas, o que nos leva a concluir que as mudanças foram impostas pelos órgãos centrais à revelia das condições das escolas, tais como equipamentos, materiais didáticos e, sobretudo, professores habilitados.

Pode-se dizer que a população rural, que sofria com as transformações decorrentes da desruralização, respondeu à pretensa homogeneidade e controle ideológico do processo de escolarização, com uma cultura de resistência. Essa resistência marcou os anos 1980, principalmente e, nem a cultura escolar autoritária e burocrática, forjada nos anos de 1970 e que desde então se instalou, principalmente a partir da Lei 5692/71; nem o tecnicismo pedagógico foram fortes o suficiente para afastar a população pobre da escola, conforme pode-se apurar com a pesquisa do desenvolvimento histórico da escola. 
De forma paradoxal, as barreiras impostas pela organização do sistema estatal, parecem fortalecer a luta por educação, tendência que se pode confirmar com os estudos de Pereira (1976) e Spósito (1992).

Para entender essa questão, o conceito de experiência histórica e cultural formulado por Thompson (1998) pode ajudar. O autor, ao estudar a formação da classe operária inglesa, nos orienta que as experiências históricas e culturais fazem o papel de catalisadores da ação social, na medida em que provocam a desvinculação entre a cultura que se estabeleceu historicamente e a estrutura econômica material.

Assim, compreende-se que a experiência acumulada pela população ao longo do tempo nas lutas sociais proporcionou aos agentes, a incorporação, a criação e reinterpretação de valores. Deve-se ter uma compreensão dialética da relação entre o ser social (a posição que ocupa nas relações de produção) e as forças condicionantes da trama social. Pode-se dizer, portanto, que se desenvolveu nos bairros uma cultura de resistência, tal como apontada por Thompson (1998). Essa resistência marcou os anos 80, principalmente e, nem mesmo a cultura escolar, apoiada na burocracia do Estado que se forjou nos anos de 1970, marcada fortemente pelo autoritarismo da tecnoburocracia que desde então se instalou, principalmente a partir da |Lei 5692/71 e pelo tecnicismo pedagógico foram fortes 0 suficiente para afastar a população pobre da escola.

Conforme Whitaker (2001), é uma falácia pensar a política educacional separando a educação urbana da educação rural. O universo que hoje se apresenta é o rural urbano, pois crianças e jovens buscam, na escola, aprender os códigos valorizados na sociedade atual. Do ponto de vista coletivo, as entrevistas apontam que a necessidade de se melhorar as condições em que era oferecida a educação das crianças e jovens serviu como fator de coesão, que perpassou todas as camadas sociais residentes nos bairros do Portão e Água Espraiada.

Foi visto no capítulo 3 que a escola, através das duas décadas que está se estudando, foi aos poucos se configurando. De uma casinha cedida por sitiantes, a escola foi se tornando um bem público valorizado pela população. Ao mesmo tempo foi assumindo características de unidade burocrática, única representante local do poder do Estado. De forma paradoxal, quanto mais a população precisa da escola em virtude das demandas da urbanização, mais ela perde autonomia. Ainda que fosse restrita, a população exercia influência e certo controle. Mas, à medida que a 
escola vai oferecendo níveis mais elevados de ensino, aumenta o controle burocrático do Estado, as exigências administrativas e a constante evolução da degradação do sistema de ensino.

Se até meados da década de 1960 verificaram-se níveis muitos baixos de evasão e retenção escolar, os efeitos do controle foram sentidos nas próximas gerações. A perda de autonomia por parte dos professores e da escola em relação ao trabalho pedagógico foi causa e conseqüência do tecnicismo adotado a partir dos anos 70, que resultou na má qualidade educacional na totalidade, incluindo as escolas rurais. A partir dos anos 80, a aferição dos índices de evasão e repetência, justificou o fechamento das escolas rurais, conforme foi possível verificar nesse estudo: das mais de cinco escolas existentes na região dos bairros Portão e Água Espraiada, apenas uma resistiu às imposições do tecnicismo e permanece em atividade até os dias de hoje.

Essas considerações finais devem ser compreendidas num contexto de limitações metodológicas e de existência de fontes mais precisas sobre a educação rural no Brasil, especialmente no Estado de São Paulo. Do ponto de vista metodológico, a história oral reflete a percepção dos sujeitos num determinado contexto social e econômico. Não é possível, portanto, generalizar os achados empíricos para situações diferentes. No que tange às fontes bibliográficas, identificou-se uma ausência de pesquisas atuais, que reflete a baixa importância que é dada ao tema da educação rural, em que pese o crescimento de estudos relacionados à educação do campo que, especificamente no Estado de São Paulo, é circunscrita aos movimentos sociais.

Não obstante as limitações assinaladas, esse estudo revela importantes questões a serem exploradas em estudos futuros. As rupturas provocadas pela perda da posse da terra, da identidade alimentar corrompida pela industrialização, e pelo fenômeno do assalariamento, são temas que podem ser mais bem explorados.

Espera-se que essa dissertação possa contribuir para o melhor entendimento das questões relacionadas à educação rural que, a despeito das políticas educacionais contrárias ao seu vicejamento, ainda resiste e atende parcela considerável de crianças e jovens que vivem nas franjas do rural-urbano. 


\section{Bibliografia:}

ACCIOLY E SILVA, Dóris. Ensino Superior: um estudo de memória social. Araraquara, SP. , 1995 (dissertação de mestrado- UNESP)

ACCIOLY E SILVA, Dóris. Repressão política, resistência e memória social: um estudo de caso in WHITAKER e VELÔSO (Org.). Oralidade e Subjetividade - os meandros infinitos da memória. Campina Grande, Eduep. 2005.

ANTUNIASSI, Maria Helena R. - Trabalho infantil e escolarização no meio rural. Zahar Editora, RJ., 1983.

ARAPIRACA, José Oliveira - A USAID e a educação brasileira, Ed. Autores Associados, São Paulo, 1982.

ARROYO, Miguel. CALDART, Roseli S., MOLINA, Mônica C. (orgs.) - Por uma Educação do Campo.,Petrópolis,Vozes, 2004.

BOSI, Ecléa - Memória e Sociedade: Lembrança de Velhos. São Paulo, T.A. Queiroz Ed., 1979.

BOURDIEU, Pierre e PASSERON, Jean-Claude - A reprodução: Elementos para uma teoria do sistema de ensino, Livraria Francisco Alves Editora S/A, RJ, 1975 Idem, ROSENDO, Ana Paulo, Recensão, Coleção Recensões LusoSofia, Universidade da Beira, Covilha, 2009 . WWW.lusosofia.net

BRANDÃO, Carlos R. - O Trabalho de Saber: Cultura camponesa e escola rural. São Paulo, FTD, 1990.

BRANDÃO, Carlos R. - O que é educação. São Paulo. Brasiliense. 2005.

BRANDÀO, Carlos R. - Casa de Escola - Cultura camponesa e educação rural. Ed. Papirus, Campinas, SP. 1984.

BRUNO. Lúcia E. N.B. - Educação e Cultura na Sociedade Contemporânea. São Paulo. s/d. (mimeo).

CAMPOS, Judas Tadeu - A relação entre a escola rural e a cultura caipira. Revista Ciências Humanas, v. 9, n. 2, Taubate - SP, 2003.

CARDOSO, F.H.C. e IANNI, Octavio (orgs.). - Homem e Sociedade: leituras básicas de sociologia geral. São Paulo. Ed. Nacional, 1984.

CERTEAU, Michel - A invenção do cotidiano: Artes de fazer. Ed. Vozes, Petrópolis, RJ. 1998.

CHIAVENATO, Júlio J. O golpe de 64 e a ditadura militar. São Paulo. Ed. Moderna. 1994. 
CONTI, João B. - História de Atibaia. V. I e II., Atibaia, Prefeitura de Atibaia, 2001. CUNHA, Luiz A. - Educação e Desenvolvimento no Brasil.Rio de Janeiro. Francisco Alves, 1980.

CUNHA, Luiz A.; GÓES, Moacyr de - O golpe na educação.Rio de Janeiro, J. Zahar Ed., 1985.

CORTINA, Roseana Leite - Burocracia e Educação: O diretor de escola no estado de São Paulo, Editora da Unesp., 1999.

DAMASCENO Maria Nobre e BESERRA Bernadete. Estudos sobre educação rural $n$ Brasil: estado da arte e perspectivas in Educação e Pesquisa. V.30. USP, 2004.

DEMARTINI, Zeila de Brito F. - Uma visão histórico-sociológica da educação da população rural em São Paulo. Cadernos CERU, n. 15, Série 1, São Paulo, 1981.

DEMARTINI, Zeila de Brito F. - Observações sociológicas sobre um tema controverso: população rural e educação em São Paulo. (tese doutorado). FFLCHUSP, São Paulo, 1979.

DENSIN, N.K., LINCOLN, Y.S. - O planejamento da pesquisa qualitativa: teorias e abordagens. Artmed. Porto Alegre-RS., 2006.

ENGELS, F. - A origem da família, da propriedade privada e do Estado. Rio de Janeiro, Ed. Global, 1986.

FAZENDA, Ivani C. Arantes - Educação no Brasil, anos 60: O pacto do silêncio. Ed. Loyola, São Paulo, 1985.

FENG Lee Y e FERRANTE, Vera L.S.Botta - A educação rural no contexto prático, dilemas e dificuldades .www.uniara.com.br/nupedor. 2006.

FERNANDES, Florestan - A Revolução Burguesa no Brasil. Petrópolis. Ed. Vozes, 1980.

FREIRE, Paulo - Pedagogia do Oprimido. Ed. Paz e Terra, RJ., 1977.

FREIRE, Paulo - Extensão ou comunicação. Ed. Paz e Terra, RJ, 1983.

FREITAS, Marcos Cezar de - Alunos rústicos, arcaicos \& primitivos: O pensamento social no campo da educação. Cortez Editora, São Paulo, 2005.

GARNICA, Antonio Vicente M. - Memórias de uma escola isolada rural: estudo de um livro de visitas (1928-1948), Educação e Sociedade, n. 114, v. 32, Campinas, 2011.

GERMANO, José Willington - Estado militar e educação no Brasil (1964-1985). Cortez Ed., São Paulo, 1992. 
HIDALGO, Kênia Ribeiro da Silva - Fracasso escolar: uma violência simbólica na perspectiva sociológica de Bourdieu. Revista Publicatio, v. 22, n. 2. UEPG. 2014. IANNI, Octavio - Estado e Planejamento Econômico no Brasil. Rio de Janeiro, Civilização Brasileira, 1986.

IANNI, Octavio - O colapso do populismo no Brasil. Rio de Janeiro, Civilização Brasileira, 1975.

LEITE, Sérgio C. - Escola Rural: urbanização e políticas educacionais. São Paulo. Cortez Ed., 1999.

LESSA Sergio- Lukács e a ontologia: uma introdução. WWW.revistaoutubro/edições/05/out./06.

LÜDKE, Menga e ANDRÉ, Marli E.D.A. Pesquisa em educação: abordagens qualitativas. São Paulo. EPU.1986.

MAIA, Eni M. - Educação Rural no Brasil: o que mudou em 60 anos?,Brasilia, Em Aberto, ano 1 n. 9, 1982.

MARQUES, Gabriel Garcia - Viver para contar. São Paulo, Record, 2010.

MARTINS, José de Souza. Expropriação \& Violência (a questão política no campo). São Paulo, Ed. Hucitec, 1980.

MARTINS, José de Souza - O cativeiro da terra. Ed. Contexto. São Paulo, 2013. MARTINS, José de Souza - A valorização da escola e do trabalho no meio rural.Rev. C. Sociais, vol. III, número 1, São Paulo, 1972. www.repositório.ufc.br MINAYO, Maria Cecília de Souza (org.), DESLANDES, GOMES - Pesquisa Social: Teoria, método e criatividade, Ed. Vozes, Petrópolis, RJ., 2015.

MOLINA, Maria Ignez G. A crise da Escola in SÃO PAULO, Secretaria de Estado da Educação e Fundação de Estudos Agrários Luiz de Queiroz, 1983.

MONTAGNER, Miguel Ângelo - Trajetórias e biografias: notas para uma análise bourdieusiana. Sociologia. Porto Alegre, RS., ano 9 - n.17, 2007.

MOREIRA, Roberto José - Cultura, política e o mundo rural na contemporaneidade. Revista Estudos Sociais da Agricultura, RJ., 2003.

MOREIRA, Erika V. e HESPANHOL, Rosângela A. M.- O lugar como uma construção social. Revista Formação, n. 14, vol.2, 2007.

NOGUEIRA, Maria Alice; CATANI Afrânio - Pierre Bourdieu: escritos de educação. Petrópolis, RJ, Ed. Vozes, 2007. 
NOGUEIRA, Maria Alice, MARTINS, Cláudia M. - A sociologia da educação de Pierre Bourdieu: limites e contribuições. Rev. Educação e Sociedade, Campinas, ano XXIII, n. 78, 2002.

NOGUEIRA, Maria Alice, ROMANELLI, Gerado, ZAGO, Nadir (org.). - Família e escola: trajetórias de escolarização em camadas médias e populares. Ed. Vozes, Petrópolis, RJ, 2000.

OLIVEIRA, Ariovaldo U. de - Modo Capitalista de Produção e Agricultura. São Paulo. Ed. Ática, 1990.

PAIVA, Dalva Infantini - Crianças da zona rural, alunos de escola urbana. (dissertação mestrado), IEL - UNICAMP, 2008.

PATTO, Maria Helena S. - A produção do fracasso escolar: histórias de submissão e rebeldia. Ed. Casa do Psicólogo. São Paulo. 1999.

PEREIRA, João Baptista Borges - A escola secundária numa sociedade em mudança. Ed. Pioneira, São Paulo, 1976.

PEREZ, José Roberto Rus - A política educacional do Estado de São Paulo 19671990. (tese doutorado) FE- UNICAMP, 1994.

PORTELLI, Alessandro - A lógica das narrativas e a aprendizagem da diferença na pesquisa de campo in WHITAKER e VELOSO (orgs.) - Oralidade e Subjetividade: os meandros infinitos da memória. Campina Grande.PB, Eduep. 2005.

QUEIROZ, Maria Isaura Pereira de. Variações sobre a técnica de gravador no registro da informação viva. T.A. Queiroz Editor Ltda. São Paulo, 1991

RIBEIRO, Maria Luisa S. - História da Educação Brasileira: A organização escolar. Campinas, SP., Autores Associados, 2003.

RIBEIRO, Marlene - Educação do campo: a emergência de contradições. In GRACINDO, Regina Vinhaes (org.) -Educação como exercício de diversidade: estudos em campos de desigualdades sócio-educacionais. Brasília, LGE Ed., 2007. RIBEIRO, Marlene - Desafios postos à educação do campo. Revista HISTEDBR online, Campinas, www.fe.unicamp.br/revistas.

ROMANELLI, Otaíza de O. - História da Educação no Brasil. Petrópolis.RJ. Vozes, 1984.

SANTOS, Jânio Ribeiro - Da educação rural à educação do campo: um enfoque sobre as classes multisseriadas. IV Colóquio Internacional Educação e Contemporaneidade. Laranjeiras - SE., 2010.

SANTOS, Milton - O espaço do cidadão. Edusp. São Paulo. 2007. 
SAVIANI, Dermeval. A nova lei da educação - LDB: Trajetória, limites e perspectivas. Campinas. Autores Associados. 1997.

SCHWARTZMAN Simon, BOMENY Helena M.B., COSTA, Vanda M. (orgs.). Tempos de Capanema. São Paulo. Ed. Paz e Terra. 2000.

SETTON, Maria da Graça J. - A teoria do habitus em Pierre Bourdieu: uma leitura contemporânea, Revista Brasileira de Educação, n. 20. 2002.

SIMSON, Olga R. de Moraes Von (org.) - Experimentos com histórias de vida (ItáliaBrasil).Edições Vértice, São Paulo, 1988).

SPOSITO, Marília Pontes - O povo vai à escola: A luta popular pela expansão do ensino público em São Paulo. Ed. Loyola, São Paulo, 1992.

SOUZA, Maria Antonia - Educação do Campo: políticas, práticas pedagógicas e produção científica. Educação e Sociedade, v. 29, Campinas, 2008.

THIOLLENT, Michel. Crítica Metodológica, investigação social e enquete operária. São Paulo, Polis Ltda., 1987.

TRIGO, Maria Helena B. - Habitus, campo estratégia. Cadernos CERU, Série 2, n. 9. São Paulo, 1998.

VELÔSO e WHITAKER, Dulce e Thelma M.G. .Oralidade e Subjetividade- os meandros infinitos da memória. Campina Grande, Eduep. 2005.

WHITAKER, Dulce C.A. Sociologia Rural - Questões metodológicas emergentes. Presidente Venceslau, SP. Ed. Letras à Margem, SP.2002.

WHITAKER, Dulce C.A. Idelogia e Práticas Culturais: O controle ideológico dos trabalhadores da cana. São Paulo. 1984 (tese de doutorado).

WHITAKER, Dulce C.A. Violência na Escola - in Idéias 21, Violência, um retrato em branco e preto. Governo do Estado de São Paulo. São Paulo, FDE, 1994.

WHITAKER, Dulce C.A. Escola, violência e trabalho infantil no Brasil, in Idéias 21, Violência, um retrato em branco e preto. Governo do Estado de São Paulo, São Paulo, FDE, 1994.

WHITAKER, Dulce C.A. - A seleção dos privilegiados: Um estudo sobre a educação brasileira. Ed. Semente, São Paulo, 1981.

WHITAKER, Dulce C.A. - Nas franjas do rural urbano: Meninas entre a tradição e a modernidade. Caderno Cedes, ano XXI, n. 56, 2002.

WHITAKER, Dulce C.A. e BEZZON, lara C. - A cultura e o ecossistema: reflexões a partir de um diálogo Ed. Alínea, Campinas. 2006. 
VIEIRA, Evaldo - A República brasileira - 1951-2010: De Getúlio a Lula. Ed. Cortez, São Paulo, 2015.

VIEIRA, Sofia L. e FARIAS, Isabel M.S. (orgs.). - Política Educacional no Brasil: Introdução histórica. Brasília. Plano Ed., 2003.

XAVIER, Maria Elizabete S.P. -Capitalismo e Escola no Brasil - A constituição do Liberalismo em Ideologia Educacional e as Reformas do Ensino (19311961).Campinas,SP., Papirus, 1990.

DOCUMENTOS CONSULTADOS DO ACERVO DA EE Profa. ZILAH B. PACITTI MUNICÍPIO DE ATIBAIA - SP.

Livro de Inventário da Primeira Escola Mista de Emergência do Bairro da Água Espraiada - 1945 a 1990.

Livro de Inventário da Escola Rural do Sítio Ângelo Poloni - 1945 a 1976.

Livro de Matrícula da Escola Mista do Bairro do Portão - 1959 a 1967.

Livro de Atas das Palestras Pedagógicas do Curso Noturno da Escola Masculina do Bairro do Portão - 1951 a 1971.

Livro Termo de Visita e Ata de Conselho da Escola Mista do Bairro da Água Espraiada - 1952 a 1977.

Livro Termo de Visita e Atas de Exames da Terceira Escola Mista do Bairro do Portão - 1968-1971.

Livro de Atas de Exames das Escolas Agrupadas do Bairro do Portão - 1971 a 1982.

Livro de Atas das Reuniões Pedagógicas das Escolas Agrupadas do Bairro do Portão - 1971 a 1986.

Livro de Atas do Conselho de Classe da Escola de Emergência do Bairro do Portão -1971 a 1976.

Livro de Atas do Conselho de Classe da EEPG Prof. Zilah Barreto Pacitti - 1978 a 1987.

Livro de Atas do Conselho de Classe da Segunda EEPG Isolada do Bairro da Água Espraiada - 1981 a 1990.

Livro de Matrícula da Escola de Emergência do Bairro da Água Espraiada - 1971 a 1984.

Livro de Registro das aulas de Ensino Religioso das Escolas Agrupadas do Bairro do Portão - 1972 a 1976. 
Livro de Registro das aulas de Ensino Religioso das Escolas Agrupadas do Bairro do Portão - 1977 a 1978. 